\title{
Paleontology of Late Proterozoic and Early Cambrian Rocks of East-Central Alaska
}

U.S. GEOLOGICAL SURVEH PROFESSIONAL PAPER 1449

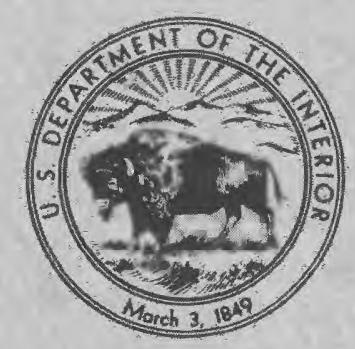




\section{AVAILABILITY OF BOOKS AND MAPS OF THE U.S. GEOLOGICAL SURVEY}

Instructions on ordering publications of the U.S. Geological Survey, along with prices of the last offerings, are given in the current-year issues of the monthly catalog "New Publications of the U.S. Geological Survey." Prices of available U.S. Geological Survey publications released prior to the current year are listed in the most recent annual "Price and Availability List." Publications that are listed in various U.S. Geological Survey catalogs (see back inside cover) but not listed in the most recent annual "Price and Availability List" are no longer available.

Prices of reports released to the open files are given in the listing "U.S. Geological Survey Open-File Reports," updated monthly, which is for sale in microfiche from the U.S. Geological Survey, Books and Open-File Reports Section, Federal Center, Box 25425, Denver, CO 80225. Reports released through the NTIS may be obtained by writing to the National Technical Information Service, U.S. Department of Commerce, Springfield, VA 22161; please include NTIS report number with inquiry.

Order U.S. Geological Survey publications by mail or over the counter from the offices given below.

\section{BY MAIL}

\section{Books}

Professional Papers, Bulletins, Water-Supply Papers, Techniques of Water-Resources Investigations, Circulars, publications of general interest (such as leaflets, pamphlets, booklets), single copies of Earthquakes \& Volcanoes, Preliminary Determination of Epicenters, and some miscellaneous reports, including some of the foregoing series that have gone out of print at the Superintendent of Documents, are obtainable by mail from

\section{U.S. Geological Survey, Books and Open-File Reports Federal Center, Box 25425 Denver, CO 80225}

Subscriptions to periodicals (Earthquakes \& Volcanoes and Preliminary Determination of Epicenters) can be obtained ONLY from the

\section{Superintendent of Documents \\ Government Printing Office \\ Washington, D.C. 20402} ments.)

(Check or money order must be payable to Superintendent of Docu-

\section{Maps}

For maps, address mail orders to

$$
\begin{gathered}
\text { U.S. Geological Survey, Map Distribution } \\
\text { Federal Center, Box } 25286 \\
\text { Denver, CO } 80225
\end{gathered}
$$

Residents of Alaska may order maps from

$$
\begin{gathered}
\text { Alaska Distribution Section, U.S. Geological Survey, } \\
\text { New Federal Building - Box } 12 \\
101 \text { Twelfth Ave., Fairbanks, AK } 99701
\end{gathered}
$$

\section{OVER THE COUNTER}

\section{Books}

Books of the U.S. Geological Survey are available over the counter at the following Geological Survey Public Inquiries Offices, all of which are authorized agents of the Superintendent of Documents:

- WASHINGTON, D.C.--Main Interior Bldg., 2600 corridor, 18 th and C Sts., NW.

- DENVER, Colorado--Federal Bldg., Rm. 169, 1961 Stout St.

- LOS ANGELES, California--Federal Bldg., Rm. 7638, 300 N. Los Angeles St.

- MENLO PARK, California--Bldg. 3 (Stop 533), Rm. 3128, 345 Middlefield Rd.

- RESTON, Virginia--503 National Center, Rm. 1C402, 12201 Sunrise Valley Dr.

- SALT LAKE CITY, Utah--Federal Bldg., Rm. 8105, 125 South State St.

- SAN FRANCISCO, Callfornia--Customhouse, Rm. 504, 555 Battery St.

- SPOKANE, Washington--U.S. Courthouse, Rm. 678, West 920 Riverside Ave.

- ANCHORAGE, Alaska--Rm. 101, 4230 University Dr.

- ANCHORAGE, Alaska--Federal Bldg, Rm. E-146, 701 C St.

\section{Maps}

Maps may be purchased over the counter at the U.S. Geological Survey offices where books are sold (all addresses in above list) and at the following Geological Survey offices:

- ROLLA, Missouri--1400 Independence Rd.

- DENVER, Colorado--Map Distribution, Bldg. 810, Federal Center

- FAIRBANKS, Alaska--New Federal Bldg., 101 Twelfth Ave. 


\title{
Paleontology of Late Proterozoic and Early Cambrian Rocks of East-Central Alaska
}

\author{
By CAROL WAGNER ALLISON
}

U.S. GEOLOGICAL SURVEY PROFESIONAL PAPER 1449

A total of 37 species-level taxa referable to the bacteria, cyanobacteria, algae, acritarcha, fungi, porifera, coelenterata or arthropoda, and one trace fossil from Late Proterozoic and Early Cambrian nonstromatolitic horizons in east-central Alaska are described and compared with similar fossils elsewhere 


\title{
DEPARTMENT OF THE INTERIOR DONALD PAUL HODEL, Secretary
}

\section{U.S. GEOLOGICAL SURVEY}

Dallas L. Peck, Director

\begin{abstract}
Any use of trade names and trademarks in this publication is for descriptive purposes only and does not constitute endorsement by the U.S. Geological Survey
\end{abstract}

\section{Library of Congress Cataloging-in-Publication Data}

Allison, Carol Wagner.

Paleontology of Late Proterozoic and Early Cambrian rocks of east-central Alaska.

(Paleontology of Alaska) (Geological Survey professional paper ; 1449)

Bibliography: p.

Supt. of Docs.: 19.16:1449

1. Paleontology-Precambrian. 2. Paleontology-Cambrian. 3. Paleontology-Alaska. I. Title. II. Series. III. Series: Geological Survey professional paper ; 1449.

For sale by the Books and Open-File Reports Section, U.S. Geological Survey, Federal Center, Box 25425, Denver, CO 80225 


\section{CONTENTS}

Abstract - . . . . . . . . . . . . . . . Introduction - - - - - - - - - - - - Acknowledgments _... . . . . . . . . . -

General stratigraphy and collecting areas - - . - - - Eagle area - . . . . . . . . . . . . . . Tatonduk area - - - - - - - - - . - - Nation area _...... . . . . . . . . Woodchopper area - . - . - . - . . . . Correlation - . - . . - . - . - . . . . -

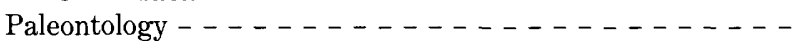
Sampling procedures - $-\ldots \ldots \ldots$ Laboratory procedures - . - . . . - . . . . Interpretation - - - - - - - - - - - - -

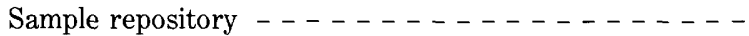

Systematic paleontology - _ - . - . - . - . - -

Bacteria - . . . . . . . . . . . . .

Genus Eoastrion - . . . . . . . . . -

?Eoastrion sp. - . - . - _ . . . -

Cyanobacteria _..................

?Order Pleurocapsales _. . . . . . . . . . Genus Sphaerocongregus - - - . - . - Sphaerocongregus variabilis _....... ?Sphaerocongregus sp. - - - - - - Genus Bavlinella _. . . . . . . . . . . Bavlinella sp., Nation area - - . - . Bavlinella sp., Eagle area - . . . . . Sphaerocongregus and Bavlinella _....... Biologic affinity _. . . . . . . . Age _... . . . . . . . . .

Order Nostocales - . . . . . . . . . . .

Family Nostocaceae _. . . . . . . . Genus Paleonostocalia _... . . . . . Paleonostocalia irregularia - - . - -

?Cyanobacteria _. . . . _ . . . . . . . .

Filament Type A - - . - . - . - . -

Filament Type B - . . . . . . . . . . -

Filament Type C - . - . . . - . . .

Coccoid Type A _. . . . . . . . . -

Coccoid Type B - . - . $\ldots \ldots \ldots \ldots$

Acritarcha _. . . . . . . . . . . . . .

Acanthomorphitae - . . . . . . . . . -

Acanthomorph Type A - - . - . - - -

Acanthomorph Type B - . . . . . . . .

Protista Incertae Sedis _. _ . . . . . . . -

Type A - . . . . . . . . . . . .

Type B - . . . . . . . . . . . .

Type C $-\cdots-\cdots-\cdots-\cdots-\cdots-\cdots$

Type D - . . . . . . . . . . .

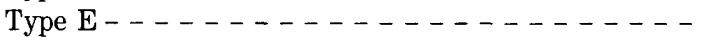

\begin{tabular}{r|} 
Page \\
1 \\
1 \\
3 \\
3 \\
3 \\
4 \\
7 \\
9 \\
10 \\
10 \\
11 \\
13 \\
13 \\
13 \\
14 \\
14 \\
14 \\
14 \\
15 \\
15 \\
15 \\
15 \\
17 \\
17 \\
17 \\
18 \\
19 \\
19 \\
19 \\
19 \\
19 \\
19 \\
20 \\
21 \\
21 \\
21 \\
22 \\
22 \\
23 \\
23 \\
23 \\
23 \\
24 \\
24 \\
24 \\
24 \\
25 \\
25 \\
26
\end{tabular}

Systematic paleontology-Continued

Protista Incertae Sedis-Continued

Type F _. . . . $\ldots \ldots 27$

Type G- . - . . . . . . . . 28

Fungi _...................... 28

Phycomycetae _- - $-\ldots \ldots 28$

?Order Saprolegniales _ . . . . . . - 28

Genus Cylindromyces _......... 28

Cylindromyces septatus - . - . . - 29

?Fungi Imperfecti _... $\ldots \ldots$

Order Fungi Sporae Dispersae - _ - - - - - 30

Family Monocellae - . . . . . . . . - 30

Oval Spore Type A - . - . . . . 30

Oval Spore Type B - . - . . . - 31

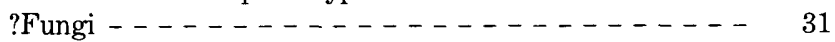

Type A - - - - - - - $-\cdots,-\cdots 31$

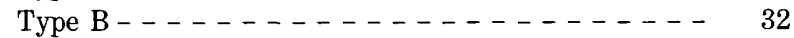

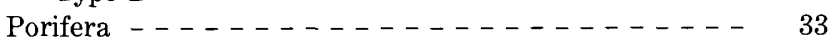

Incertae Sedis - . - . $\ldots \ldots$. 33

?Porifera - . . . . . . . . . . . . . 33

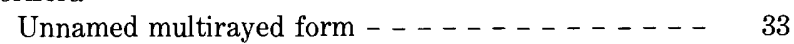

Family Chancelloriidae - . _ . . . . . . 34

Genus Chancelloria _. $\ldots \ldots \ldots 34$

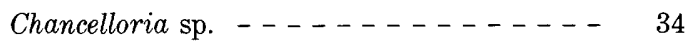

?Chancelloria Type A - . . . . . - 36

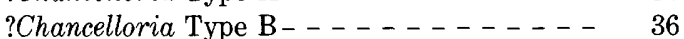

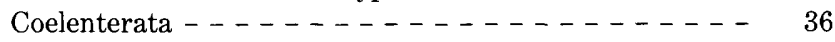

Class Anthozoa _............... 36

Genus Tabulaconus - . . . . . . . . 36

Tabulaconus kordeae _. _ _ _ _ . 36

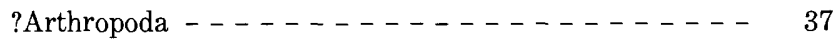

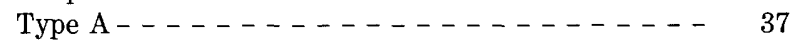

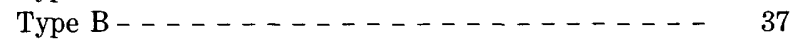

Type C - . . . . . . . . . . 37

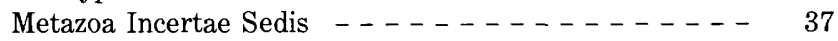

Brabbinthes churkini - . . . . . . . . . . 37

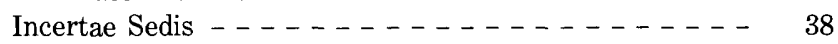

?Oldhamia _................. . 38

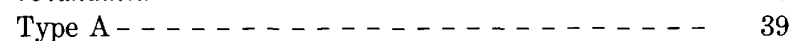

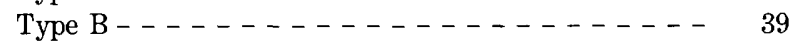

Type C - . . . . . . . . . . 39

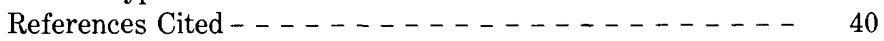

Appendix A-Locality descriptions - _ - - - - - - - 44

Appendix B-Thin-section coordinates for specimens

illustrated on plates _...

Appendix C-Coordinates for lower left corner of cover slips

of thin sections _....

Index $\ldots \ldots \ldots 49$

\section{ILLUSTRATIONS}

[Plates follow index]

Plate 1. ?Eoastrion, Tatonduk area.

2. Bavlinella, Obruchevella, other cyanobacterial, protistan, and fungal(?) microfossils, Tatonduk and Eagle areas.

3. Paleonostocalia, Nation area.

4. Paleonostocalia and cyanobacterial(?) microfossils, Nation area. 
Plate 5. ?Fungi, Nation area.

6. Chancelloria and enigmatic thready structures, Nation area.

7. ?Chancelloria and stauract spicules, Nation area.

8. Enigmatic thready structures, Nation area.

9. ?Arthropoda and Incertae Sedis, Nation area.

10. Brabbinthes, Nation area.

11. Protista, ?Porifera, and enigmatic microfossils, Nation area.

12. Cylindromyces, Sphaerocongregus, and protistan microfossils, Woodchopper area.

13. Sphaerocongregus, ?Fungi, Woodchopper area.

14. Sphaerocongregus, ?Fungi, Woodchopper area.

15. Sphaerocongregus, Woodchopper area.

16. Sphaerocongregus and protistan microfossils, Woodchopper area.

17. Acanthomorph acritarchs and other protistan microfossils, Woodchopper area.

18. Oldhamia, ?Oldhamia, Tabulaconus, and ?Arthropoda; Tatonduk, Nation, and Woodchopper areas.

Figure 1. Index map showing distribution of Middle and Late Proterozoic and Early Cambrian rocks in east-central Alaska - - -

2. Geologic map of southern Tatonduk area _ $\ldots \ldots \ldots \ldots \ldots \ldots \ldots$

3. Generalized stratigraphic column of the Tindir Group and younger rocks in Tatonduk area

4. Photomicrograph of spicules in limestone unit of the Tindir Group in northeast Tatonduk area

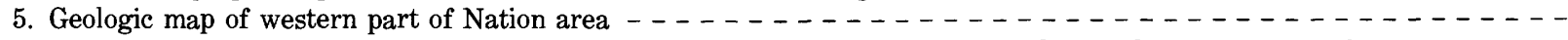

6. Generalized stratigraphic column of the Tindir and Tindir(?) Group on west bank of Yukon River in Nation area - - - -

7. Generalized stratigraphic column for Washington Creek exposures in western Nation area $\ldots \ldots$

8. Geologic map of southern part of Woodchopper area $\ldots \ldots \ldots \ldots \ldots \ldots \ldots \ldots$

9. Suggested córrelation of Middle Proterozoic to Early Cambrian rocks of east-central Alaska

10. Hypothetical growth cycle for Sphaerocongregus variabilis _ $\ldots \ldots \ldots \ldots \ldots \ldots$

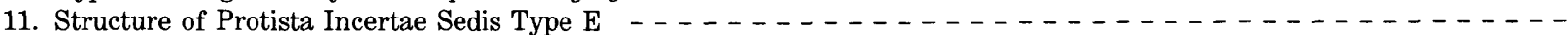

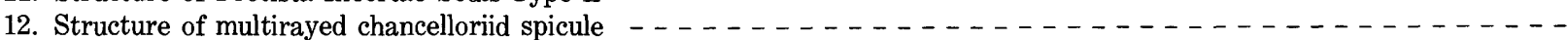




\title{
PALEONTOLOGY OF LATE PROTEROZOIC AND EARLY CAMBRIAN ROGKS OF EAST-GENTRAL ALASKA
}

\author{
By Carol Wagner Allison
}

\begin{abstract}
The Middle Proterozoic to Early Cambrian Tindir Group and related sedimentary and volcanic rocks crop out in the vicinity of the Yukon River in east-central Alaska. These exposures occur in the Eagle, Tatonduk, Nation, and Woodchopper areas. Microfossils recently discovered in all four of these areas include representatives of bacterial, algal, fungal, indeterminate protistan, and metazoan groups. Overlying rocks contain previously described Early, Middle, and Late Cambrian trilobites, archeocyathids and other shelled macrofossils.

The Eagle area exposures, not assigned to the Tindir Group, include mainly slightly metamorphosed fine-grained clastic and altered volcanic rocks. Worm traces and rare coccoid and filamentous microbial fossils in these rocks are consistent with a Late Proterozoic or Early Cambrian age.

Tatonduk area exposures include the most complete Tindir Group section. Columnar stromatolites in the dominantly dolomitic lower part of the Tindir Group have not been studied in detail and have not been analyzed for this study. The upper part of the Tindir in this area includes a unit of pyroclastic rocks and basalts associated with glacially influenced, maroon, fine- and coarse-grained clastic rocks in the basalt and red beds unit. This unit has yielded very rare apparent fungal fragments and microbial coccoids in black shale horizons. A red chert bed higher in the section contains abundant bacterial fossils reminiscent of types compared with the modern iron-depositing Metallogenium. Previously reported large species of the coiled microbe Obruchevella and newly found spicular fossils of probable poriferan affinity, in conformably overlying rocks of the upper part of the Tindir in this area, indicate an Early Cambrian age for at least the uppermost part of the Tindir Group exposed here.
\end{abstract}

Tindir and Tindir(?) rocks exposed in the Nation area include microfossiliferous exposures in two sections. Rare, poorly preserved coccoid fossils occur in the dolomite and shale unit of the lower part of the Tindir and in the dolomitic and shaly beds of the upper part of the Tindir(?) on the west bank of the Yukon River. A basinal shaly and volcanic sequence to the west contains a widely varied Cambrian biota including coccoid and filamentous microfossils, ?fungi, protistans of uncertain affinity, chancelloriid and other spicules, and fragments of additional metazoans.

Woodchopper area exposures, mainly fine-grained clastic and volcanic rocks, are not herein assigned to the Tindir Group although original depositional continuity with the Tindir and Tindir(?) of the Nation and Tatonduk areas is possible. All the fossils now known from the Woodchopper area occur in a fault-bounded belt of undivided carbonate and shaly sedimentary rocks. At Takoma Bluff, on the west bank of the Yukon River, abundant organic-walled cyanobacterial, fungal(?), and other protistan microfossils occur in a basinal limestone and shale sequence. This biota includes Sphaerocongregus variabilis Moorman, a distinctive coccoid form referred by some workers to Bavlinella, a widely known Late Proterozoic and Early Cambrian fossil. Bedding-plane worm traces occur slightly higher in this section. To the east, dark shales have yielded spiny acritarchs reminiscent of types widely known in Cambrian rocks in Asia and Europe. Bedding-plane trace fossils suggestive of Oldhamia and an apparent arthropod are also present in this area.

New species and other taxa described from east-central Alaska are: ?Sphaerocongregus sp., ?Cyanobacteria Coccoid Type B, ?Cyanobacteria Filament Type C, and Protista Incertae Sedis Type C from the Eagle area; ?Eoastrion sp. and ?Fungi Type A from the Tatonduk area; ?Cyanobacteria Coccoid Type A, Paleonostocalia irregularia n. gen. and sp., ?Cyanobacteria Filament Type B, Protista Incertae Sedis Type G, ?Fungi Type B, Chancelloria sp., ?Chancelloria Type A, ?Chancelloria Type B, Incertae Sedis Type A, Incertae Sedis Type B, and Incertae Sedis Type C from the Nation area; and Protista Incertae Sedis Type A, Protista Incertae Sedis Type B, Protista Incertae Sedis Type D, Protista Incertae Sedis Type E, Protista Incertae Sedis Type F, Acanthomorph Acritarcha Type A, Acanthomorph Acritarcha Type B, Cylindromyces septatus n. gen. and sp., ?Fungi Imperfecti Oval Spore Type A, ?Fungi Imperfecti Oval Spore Type B, and ?Oldhamia sp. from the Woodchopper area.

\section{INTRODUCTION}

Rocks of Proterozoic and Cambrian age crop out widely north of the Tintina fault in east-central Alaska (fig. 1). Exposures south of the Kandik River in the Tatonduk and the eastern part of the Nation areas are assigned to the Tindir Group, a thick sequence of largely unmetamorphosed carbonate, clastic, and volcanic rocks. The wedgeshaped area between the Tintina fault and the Dawson fault to the south exposes slightly metamorphosed carbonate, clastic, and volcanic rocks commonly accorded a Late Proterozoic (= Windermere Group) age. These rocks are not easily related to Tindir Group units north of the Dawson fault and are currently referred to informally named map units. North of the Kandik River, poorly known rocks of generally deeper water aspect are for the most part not presently assigned to the Tindir Group but offer some grounds for lithologic correlation with the Tindir and Tindir(?) of the Tatonduk and Nation areas (Payne and Allison, 1981) and contain fossils of comparable age.

Except for the vicinity of the village of Eagle, which has summer road access via the unpaved Taylor Highway, areas under study are virtually uninhabited. Heavy vegetative cover restricts good exposure to river and stream 
banks and to high elevations, primarily near the AlaskaYukon Territory border. Riverboats provide the best means of access to several important sections, but helicopter support is virtually required for examination of exposures away from the Yukon and Tatonduk Rivers. The area is snow-free from about mid-May to midSeptember.

The Tindir Group was named by Cairnes (1914) following examination of exposures in a 7-km-wide strip along the Alaska-Yukon Territory border between the Yukon River and the Porcupine River and to the north. As defined by Cairnes, the Tindir Group included exposures north of the area under discussion here. Later studies east of the Yukon River by Mertie $(1930,1933)$ provided much new information on the Tindir Group in what is here referred to as the Tatonduk area and resulted in a sevenfold subdivision of the group. Geologic mapping in the Yukon River area during the 1960's led to revision of the Tindir in the Tatonduk and Nation areas into five informal map units and to recognition of possible equivalent ages for exposures in what is here called the Woodchopper area (Brabb and Churkin, 1969). Studies of post-Tindir rocks in the Tatonduk area during this period provided a wealth of new information on the nature of overlying Cambrian rocks (Brabb, 1967) and confirmed the presence of Early as well as Middle and Late Cambrian faunas from strata lying above the Tindir Group (Palmer, 1968).

Search for microfossils in the Tindir Group and related rocks of the region was initiated by the author in 1971 with short visits to the Tatonduk River section and along

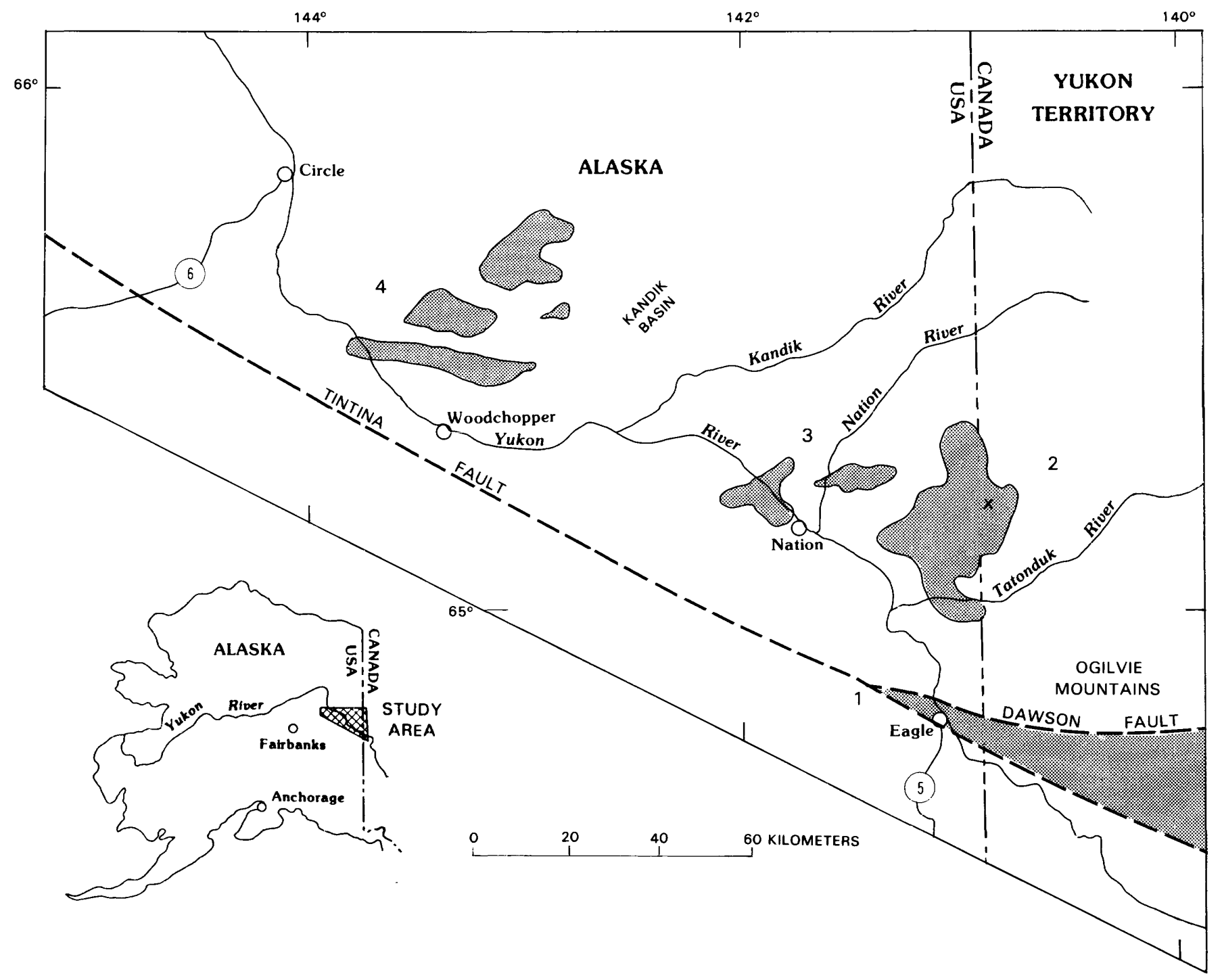

Figure 1.-Distribution of Middle Proterozoic to Early Cambrian rocks (shaded areas) in east-central Alaska. 1, Eagle area. 2, Tatonduk area. 3, Nation area. 4, Woodchopper area. $\times$ marks location of upper Tindir Creek fossils outside area of figure 2. 
the Yukon River north of Nation. Discovery of microfossils in the latter area (Allison and Moorman, 1973) led to field collection in the same areas and at Takoma Bluff in the Woodchopper area in 1973, the Eagle area in 1974, and Takoma Bluff in 1976. Brief helicopter support in 1974,1975 , and 1976 permitted examination and collection of the Washington Creek section in the western Nation area (Allison, 1975; Payne and Allison, 1978).

Recent detailed mapping of the upper part of the Tindir in the southern part of the Tatonduk area provides much new information on the stratigraphy and depositional history of these important exposures (Young, 1982). Abundant and exceptionally well preserved microbial mat biotas in the uppermost part of the Tindir in the northeast Tatonduk area (Awramik and Allison, 1980; Allison, 1981; Allison and Hilgert, 1986) are currently under study.

\section{ACKNOWLEDGMENTS}

The research program on the Tindir Group was initially supported by the University of Alaska Museum. From 1973 to 1976 the National Science Foundation provided funding through Geology Program Grants GA 43544 and EAR74-11907 for paleontologic and associated studies reported here.

Richard T. Buffler, then at the University of Alaska at Anchorage, worked without compensation on stratigraphy and depositional environments of river-level exposures below Nation and at Takoma Bluff in the Woodchopper area in 1973. This aspect of the program and study of the Washington Creek section in the Nation area were taken over by Myron W. Payne, then at the University of Alaska, from 1975 to 1977 . Excellent field assistance was provided by Leslie A. Moorman and Mary A. Moorman in 1973. Field samples and helicopter support for 1975 and 1976 field work in Washington Creek were generously provided by the Louisiana Land and Exploration Company through Bruce I. Clardy. Without this helicopter support, critical field work could not have been accomplished. David B. Stone, University of Alaska, and David Krank, C.J. Waller, and Dick Cook of Eagle, Alaska, collected samples from specific areas for the author.

Earl E. Brabb and Michael Churkin, Jr., U.S. Geological Survey, gave generous and continuing help during this study. Samples loaned by Brabb provide the only currently available fossil material from a number of important localities. Preston Cloud offered useful suggestions and access to facilities of his laboratory at the University of California at Santa Barbara. Gary L. Kline kindly provided his fossiliferous thin sections for examination. Suggestions on affinities and interpretive problems of fossils discussed in this paper were given by J. Wyatt Durham, Elso S. Barghoorn, Mary A. Moorman, John A. West, William Elsik, Patrick Flanagan, Ralph Emerson, Peter Crimes, Otto Majewski, J. Keith Rigby, Stefan Bengston, and Alan Horowitz.

\section{GENERAL STRATIGRAPHY AND COLLECTING AREAS}

The four outcrop areas shown in figure 1 have been defined primarily for convenience in discussion. Depositional relations of rocks in the Eagle area to those in the other three areas are poorly understood. Rocks in the Nation area clearly reflect depositional continuity with those in the Tatonduk area, and exposures in the Woodchopper area may include representation of Tindir Group units in the Tatonduk and Nation areas. Microfossils have been discovered in all four areas, and new trace fossil occurrences in the Woodchopper and Eagle areas have also been found. The following brief descriptions of rocks in the four areas provide a general geologic framework. Except for minor changes, geology on included maps of these areas follows that shown on the maps of Brabb and Churkin $(1965,1969)$. Stratigraphic columns provided here for microfossiliferous sections that are at least moderately well understood include most of the currently known fossil occurrences. Many fossil localities are shown on maps of the local areas, and all localities are described in detail in appendix A.

\section{EAGLE AREA}

Presumed Late Proterozoic rocks in the triangular area between the Tintina and Dawson faults continue eastward into Canada where they are commonly referred to as the grit unit, an inclusive thick package containing distinctive coarse clastic rocks and maroon and green slates or shales (Gabrielse 1967, 1972). Altered volcanic rocks are intimately associated with these sedimentary rocks in Alaska and the Yukon Territory. In Alaska the rocks are highly faulted and slightly metamorphosed. They were divided into three informal map units (limestone, greenstone, and quartzite and argillite units) by Brabb and Churkin (1965). Dark limestones with interbedded finegrained clastic rocks, dolomite, tuff, and greenstone in the limestone unit have thus far not yielded any fossils. The greenstone unit contains massive altered andesite or basalt and includes interbedded tuff, volcanic conglomerate, quartzite, argillite, shale, and chert. Microfossils have been found in this unit close to the Tintina fault 
$5.5 \mathrm{~km}$ northeast of the village of Eagle. The third map unit, the quartzite and argillite unit, contains minor shale, chert, sandy limestone, and intrusive(?) greenstone. Bedding-plane worm traces (M.W. Payne, oral commun., 1977) and boring(?) worm traces (Brabb and Churkin, 1965) occur in the quartzite. Microfossils have been found by the author in siliceous black shales of this unit on the east bank of the Yukon River north of Eagle. The combined microbiota, described below and illustrated on plate 2 , is small, and the fossils are poorly preserved although locally abundant. Taxa found are listed here.

\section{Greenstone unit \\ Bavlinella sp. \\ ?Cyanobacteria Coccoid Type B \\ ?Cyanobacteria Filament Type C \\ Protista Incertae Sedis Type C \\ Quartzite and argillite unit \\ ?Sphaerocongregus sp.}

\section{TATONDUK AREA}

The best known and apparently most complete Tindir Group section in Alaska occurs in the Tatonduk area (figs. $2,3)$. Rocks assigned to the lower part of the Tindir lie east of the Hard Luck fault and are especially well exposed in mountainous areas along the Alaska-Yukon Territory border. These structurally complex exposures have not been mapped in detail. They include a lower faultbounded sequence of (1) basal fluviatile(?) red beds, (2) overlying interbedded carbonate rocks and shales with several prominent stromatolitic horizons, and (3) overlying, dominantly quartzitic beds. Young (1982) described a section measured in the vicinity of Pleasant Creek. Soft carbonaceous dark shales with carbonate and quartzitic interbeds overlie the older rocks and are associated to the north with a resistant limestone that contains branching columnar stromatolites referred by Semikhatov (in Churkin, 1973) to Baicalia. Distinctive laminated dolomites with interbedded, thin dark shales lie at the top of the lower part of the Tindir. These have not thus far yielded fossils in the Tatonduk area but contain microfossils referred to a Late Proterozoic and Early Cambrian form in the Nation area.

Units of the upper part of the Tindir are widely present and locally well exposed in the Tatonduk area, especially in the valley of the Tatonduk River. These rocks are described in detail by Young (1982), and their age and correlation are discussed in Allison and Hilgert (1986). Informal units of the upper part of the Tindir as designated by Brabb and Churkin (1969) are the basalt and red beds unit (units 1, 2, and 3 of Young, 1982), the dolomitic sand-

stone and shale unit, and the limestone unit (units 4 and 5, respectively, of Young, 1982).

Microfossils found to date in the upper part of the Tindir occur in red chert and in rare black horizons in siliceous maroon shales of the basalt and red beds unit on the Tatonduk River. These are described below and illustrated on plates 1 and 2. The widely known Late Proterozoic,

\section{EXPLANATION}

Gris

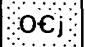

OEj

Ridge Limestone (Ordovician and Cambrian) - Lower $610 \mathrm{~m}$ gray limestone and dolomite, commonly silicified and oolitic, with Early and Late Cambrian fossils; overlain by $290 \mathrm{~m}$ tan limestone with Late Cambrian fossils, upper $18 \mathrm{~m}$ bioclastic limestone with Ordovician fossils

$\because \because \ddot{\circ} \cos$

Hillard Limestone (Ordovician and Cambrian) - Tan limestone with interbeds of conglomerate, minor dolomite, chert, and oolitic and sandy limestone. Trilobites and brachiopods common. Age is Early, Middle, and Late Cambrian and earliest Ordovician

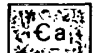

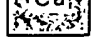

Adams Argillite (Early Cambrian)-Light-olive-gray argillite, siltstone. and quartzite. Worm burrows and bedding plane traces in quartzite. Limestones near base with Early Cambrian trilobites and archeocyathids

Funnel Creek Limestone (Early Cambrian) - Light-gray limestone and dolomite, extensively silicified and commonly oolitic. Cyanobacterial and algal microfossils near base northeast of Tatonduk River

Tindir Group (Early Cambrian to Middle Proterozoic)-In this area, divided into:

Limestone unit (Early Cambrian) - Gray to black shale and laminated limestone with platy and slabby parting, commonly fetid. Local interbeds of greenish-gray shale, siltstone, and sandstone. Algal microfossils in upper Pass Creek; bacterial, cyanobacterial, algal, other protistan, fungal, and poriferan microfossils northeast of Tatonduk River

Dolomitic sandstone and shale unit (Late Proterozoic)-Gray sand stone and olive-gray shale, minor gritstone, and conglomerate with dolomite, chert, granitic, volcanic, and metamorphic clasts

Basalt and red beds unit (Late Proterozoic)-Dark-greenish-gray basalt, commonly amygdaloidal and with pillow structures. Minor basaltic tuff. Maroon shale and minor greenish-gray shale, chert. and conglomerate. Bacterial, cyanobacterial, and fungal(?) microfossils

Dolomite and shale unit (Middle Proterozoic)-Gray laminated dolomite and grayish-black shale Minor chert, doloarenite, and gritstone. Cut by diabase dikes. Locally divided into:

Stromatolitic limestone-Medium-gray limestone. May be lateral equivalent of either the dolomite and shale or shale units. Columnar stromatolites

Shale unit (Middle Proterozoic)-Grayish-black carbonaceous shale with minor interbeds of quartzite, limestone, dolomite, and dolomite conglomerate. Cut by diabase dikes

Dolomite, shale, and quartzite unit (Middle Proterozoic) - Gray-and orange-weathering stromatolite-bearing dolomites, shales, quartzites, and limestone. Minor red beds at base. Cut by diabase dikes

Contact

- - Fault, approximately located

$\longleftarrow$ Anticline, showing crestline and direction of plunge

A-922 Fossil locality and number 


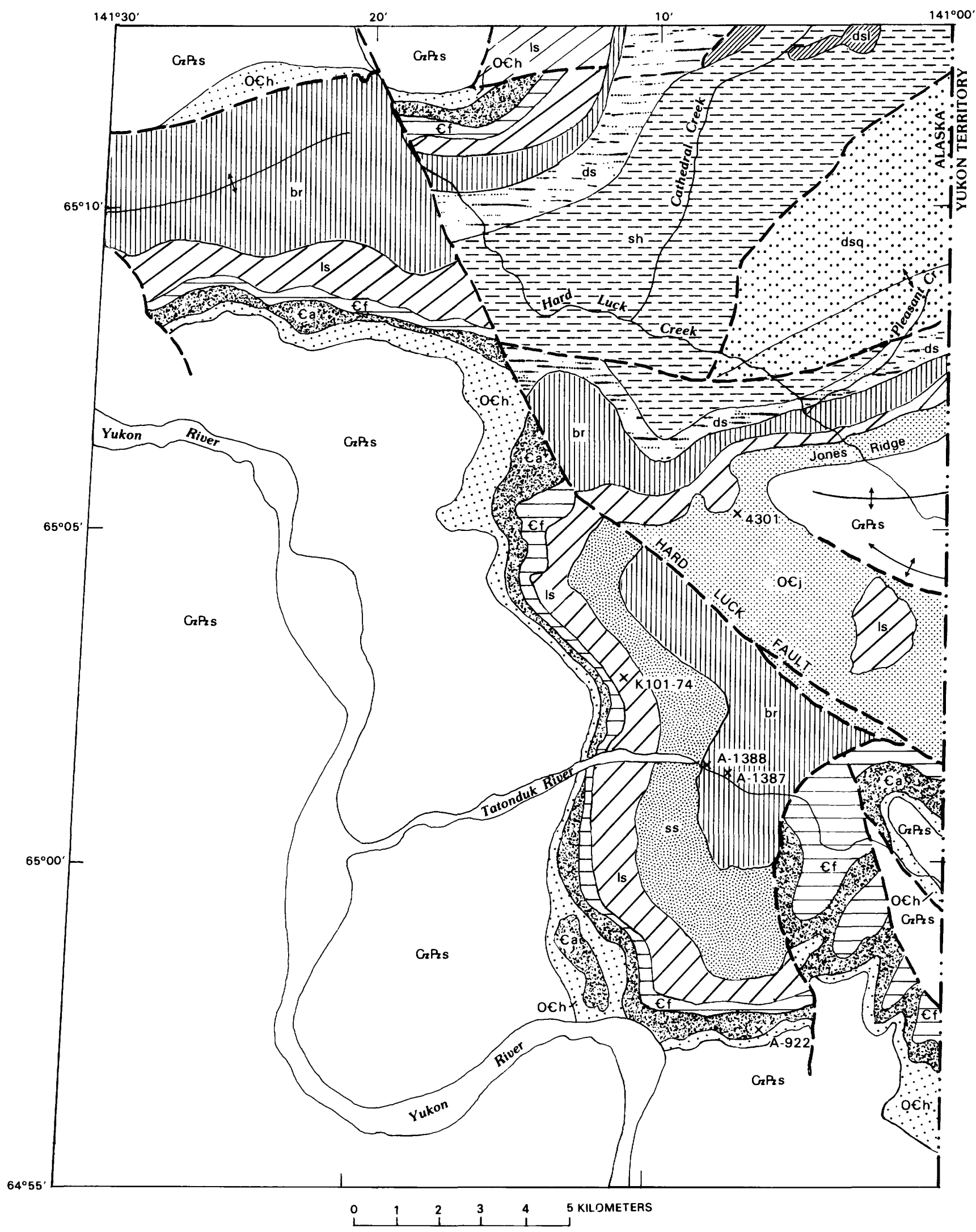

Figure 2.-Geologic map of the Tindir Group and overlying rocks in southern Tatonduk area, Alaska (modified from Brabb and Churkin, 1965, 1969). 


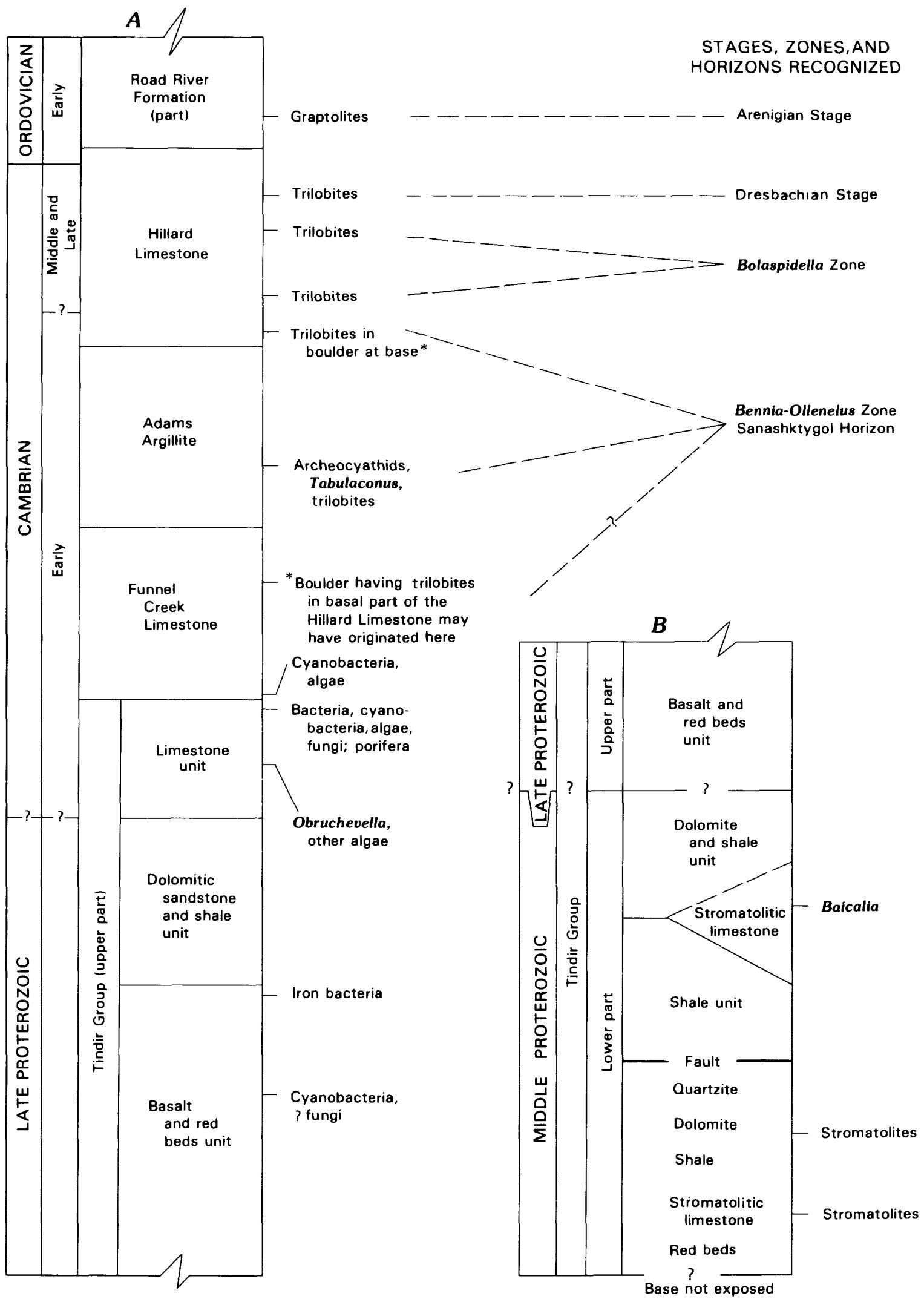

FIGURE 3.-Generalized stratigraphic column of the Tindir Group and younger rocks in Tatonduk area, Alaska (compiled from Brabb and Churkin, 1969; Young, 1982; Allison and Hilgert, 1986). A, Tatonduk River and northeast Tatonduk areas. $B$, Middle Hard Luck Creek east of Hard Luck fault. 
Cambrian, and Ordovician coiled microscopic alga Obruchevella reported by Kline (1977) and by Cloud and others (1979) occurs with filamentous algae and a distinctive organic-walled form of indeterminate affinity in the characteristically fetid limestone unit of the Tindir near the Tatonduk River. A few of these forms are shown on plate 2. More recently discovered microbiotas (Awramik and Allison, 1980; Allison, 1981; Allison and Hilgert, 1986) in the uppermost part of the Tindir in the northeast Tatonduk area contain the same distinctive organic-walled form, bacteria, cyanobacteria, algae, and indeterminate protistans and fungi as well as sponge spicules (fig. 4) that indicate a post-Proterozoic age for the limestone unit (A.R. Palmer, oral commun., 1984). Taxa found in the Tatonduk River section of the Tindir Group in the southern Tatonduk area are listed here.

Limestone unit

Obruchevella spp.

Microbial filaments

Indeterminate tubular organic-walled form

Basalt and red beds unit

?Eoastrion sp.

Indeterminate cyanobacterial unicells

?Fungi Type A

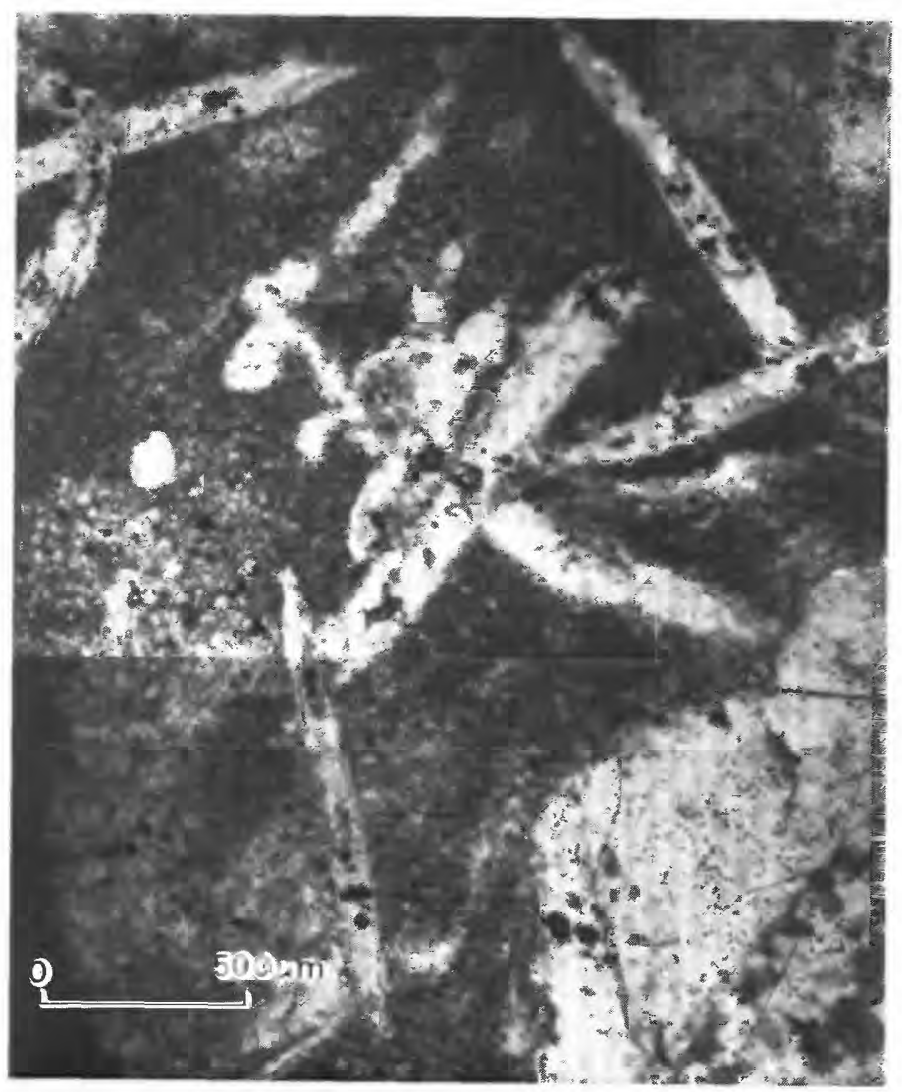

Figure 4.-Spicules in limestone unit of the Tindir Group in northeast Tatonduk area, Alaska. UAK location CA 637.

\section{NATION AREA}

Rocks of the Tindir Group and Tindir(?) Group in the Nation area have yielded fossils in three areas (fig. 5). Thin dark shales interbedded with thin, finely laminated gray dolomites of the upper part of the lower part of the Tindir on the west bank of the Yukon River below the abandoned village of Nation, and similar rocks exposed downstream that contain volcanic rocks also (fig. 6), have yielded rare, poorly preserved specimens of a Late Proterozoic and Early Cambrian microscopic form (Allison and Moorman, $1973,1974)$. The same fossils occur also in dark, thin, slightly fetid-smelling limestones at the northernmost end of the river-level Tindir exposures. These limestones are here referred to the uppermost limestone unit(?) of the Tindir(?) Group.

Volcanic and shaly beds to the west in Washington Creek (figs. 5, 7) contain a highly varied biota including cyanobacteria, apparent fungi, and spicules. These fossils are described below and illustrated on plates 3 through 11 .

Stratigraphic relations within the Washington Creek section are difficult to confirm because of complex isoclinal folding, faulting, and intermittent exposure. Juxtaposition of the argillite and quartzite beds against volcanic rocks and shales as shown on figure 7 may not reflect the original depositional superposition.

The presence of chancelloriid spicules and other shelled metazoans strongly supports a Cambrian age for the Washington Creek fossiliferous beds. This raises some question about the referral of these rocks to the basalt and red beds unit as mapped in the Tatonduk area because of the Proterozoic age currently interpreted for similar glacially influenced Cordilleran deposits. Evidence supporting assignment to the basalt and red beds unit includes (1) similarity in their mafic volcanic-, iron-, and silica-rich, finely laminar character, (2) proximity to the unquestioned lower part of the Tindir to the east and southeast along the Yukon River, and (3) presence of red beds as well as post-Tindir Early Cambrian rocks where this belt crops out across the Yukon River to the east (fig. 5). The assignment of these rocks to one of the postTindir Cambrian units of the region also raises difficult questions. The Funnel Creek and Hillard Limestones clearly offer no grounds for correlation in view of their strongly differing lithologies and lack of evidence of volcanism. The Adams Argillite is in part more promising as a potential correlative. Brabb (1967) reported two small outcrops of greenstone in the Adams Argillite. One of these, in the southeast Tatonduk area, originally suggested to be altered hornblende andesite (Brabb, 1967), was later interpreted as a diabase (Brabb and Hamachi, 1977). The other, in a complexly faulted area east of the Nation River, is reported to be altered basalt (Brabb and Hamachi, 1977). However, near the eastern end of the basalt and 
red beds unit(?) outcrop belt that includes the Washington Creek exposures (fig. 5), the Adams Argillite contains interbedded light-olive-gray argillites, quartzites, and siltstones possibly comparable to the argillite and quartzite beds of the lower(?) part, but clearly not comparable to the fossilbearing volcanic rocks and shale of the upper(?) part, of the Washington Creek section. No evidence of unconformity between the Adams Argillite and Hillard Limestone or of a break within the laterally equivalent lower part of the Jones Ridge Limestone has been reported, so there are no present grounds for a suggestion that the Washington Creek fossiliferous beds represent a facies of the Adams Argillite that has not been recognized elsewhere in the region. Taxa found in the Tindir Group and the Tindir(?) Group in the Nation area are listed here.

Yukon River sections

Limestone unit(?) Bavlinella sp.

Basalt and red beds unit(?) Bavlinella sp.
Dolomite and shale unit Bavlinella sp.

Washington Creek section

Basalt and red beds unit(?)

Paleonostocalia irregularia n. gen. and sp.

?Cyanobacteria Filament Type A

?Cyanobacteria Filament Type B

?Cyanobacteria Coccoid Type A

Indeterminate filamentous microfossils in clasts

Protista Incertae Sedis Type G

?Fungi Type B

Chancelloria sp.

?Chancelloria Type A

?Chancelloria Type B

Porifera Incertae Sedis

Brabbinthes churkini Allison, 1975

?Arthropod fragments

Indeterminate metazoan shell fragments

Incertae Sedis Type A

Incertae Sedis Type B

Incertae Sedis Type C

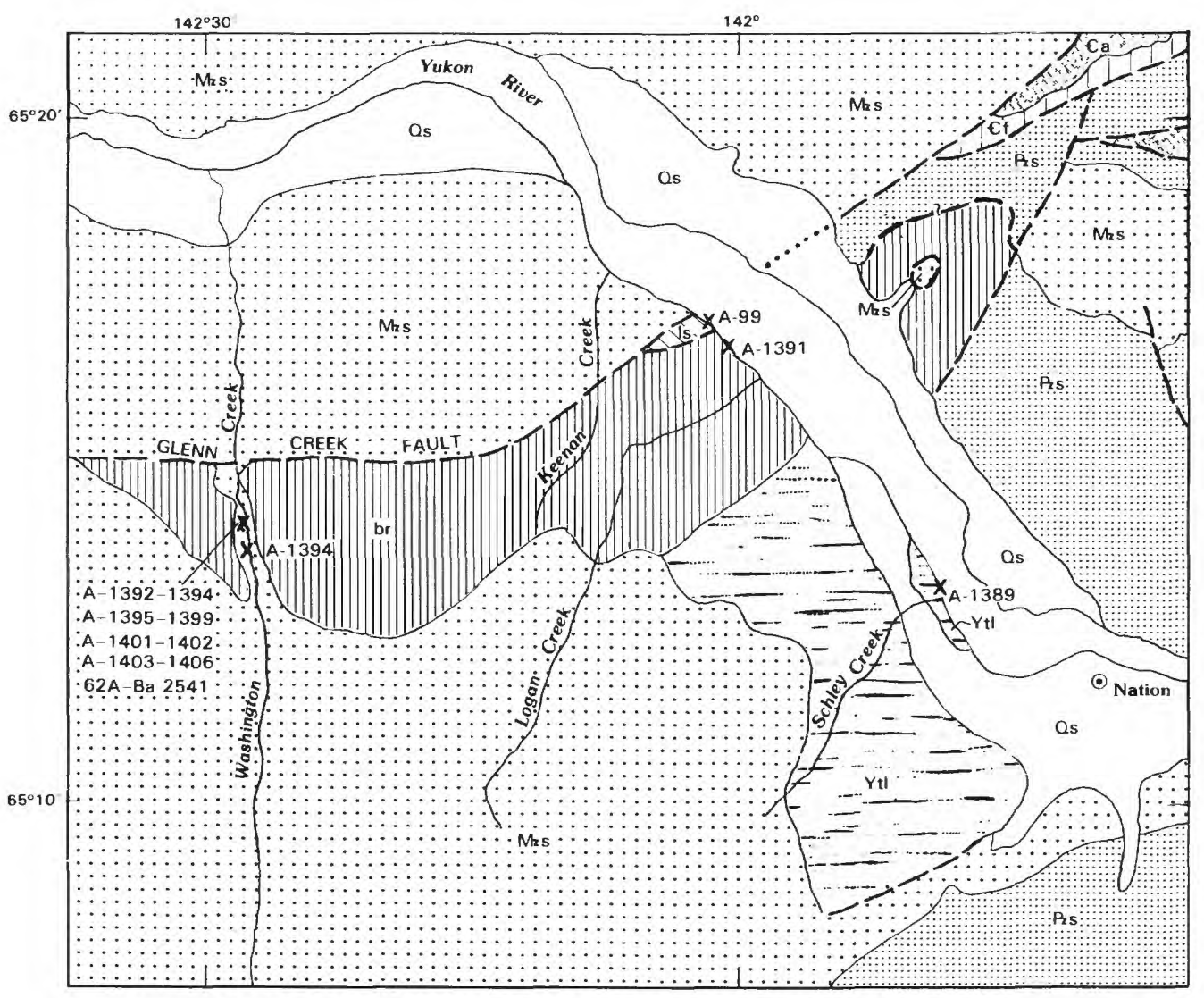

L
10 15 KILOMETERS

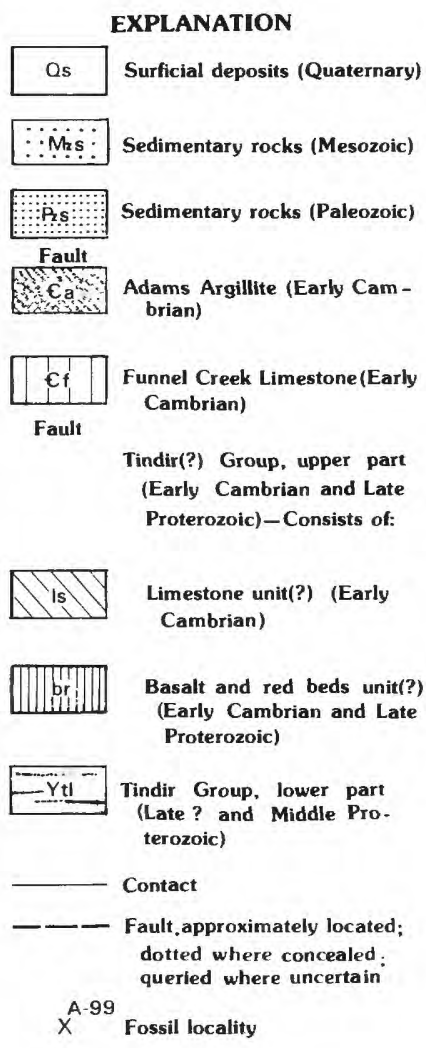

FIGURE 5.-Geologic map of western part of Nation area, Alaska (modified from Brabb and Churkin, 1969). 


\section{WOODCHOPPER AREA}

Rocks of apparent Middle and Late Proterozoic age in the Woodchopper area (fig. 8) have been referred by Brabb and Churkin (1969) to four informal map units (dsl, $\mathrm{p} € \mathrm{~d}, \mathrm{p} \in \mathrm{v}$, and $\mathrm{p} € \mathrm{u}$ ). Unit dsl, which is known only in a small fault-bounded sliver to the east, contains stromatolitic limestones. Identification based on limited material indicates that Baicalia is present in these limestones (Semikhatov, in Churkin, 1973), thus this exposure has been referred to the upper part of the lower part of the Tindir. The remaining three map units consist of one $(p \in d)$ characterized by laminated dolomite with chert and minor coarse- to fine-grained clastic materials, a basaltic unit $(\mathrm{p} \in \mathrm{v})$ with pyroclastic rocks and minor carbonate and clastic interbeds, and a third unit $(\mathrm{p} \in \mathrm{u})$ of undivided sedimentary rocks including dark laminated limestone with shale, argillite, chert, and dolomite. All of the fossils found thus far in these rocks occur in the undivided unit in a fault-bounded east-west elongate block (fig. 8). The primary collecting area is at Takoma Bluff on the west bank of the Yukon River where a thick unit of thinbedded, dark-gray and black indurated limestone contains siliceous shale interbeds that have yielded abundant, primarily organic-walled plant microfossils described below and illustrated on plates 12 through 16 . These fossils include the distinctive Sphaerocongregus variabilis Moorman (1974), apparent fungal spores and filaments, and several additional new microfossils of uncertain affinity. Bedding-plane traces reminiscent of Planolites are present in limestone that conformably overlies the

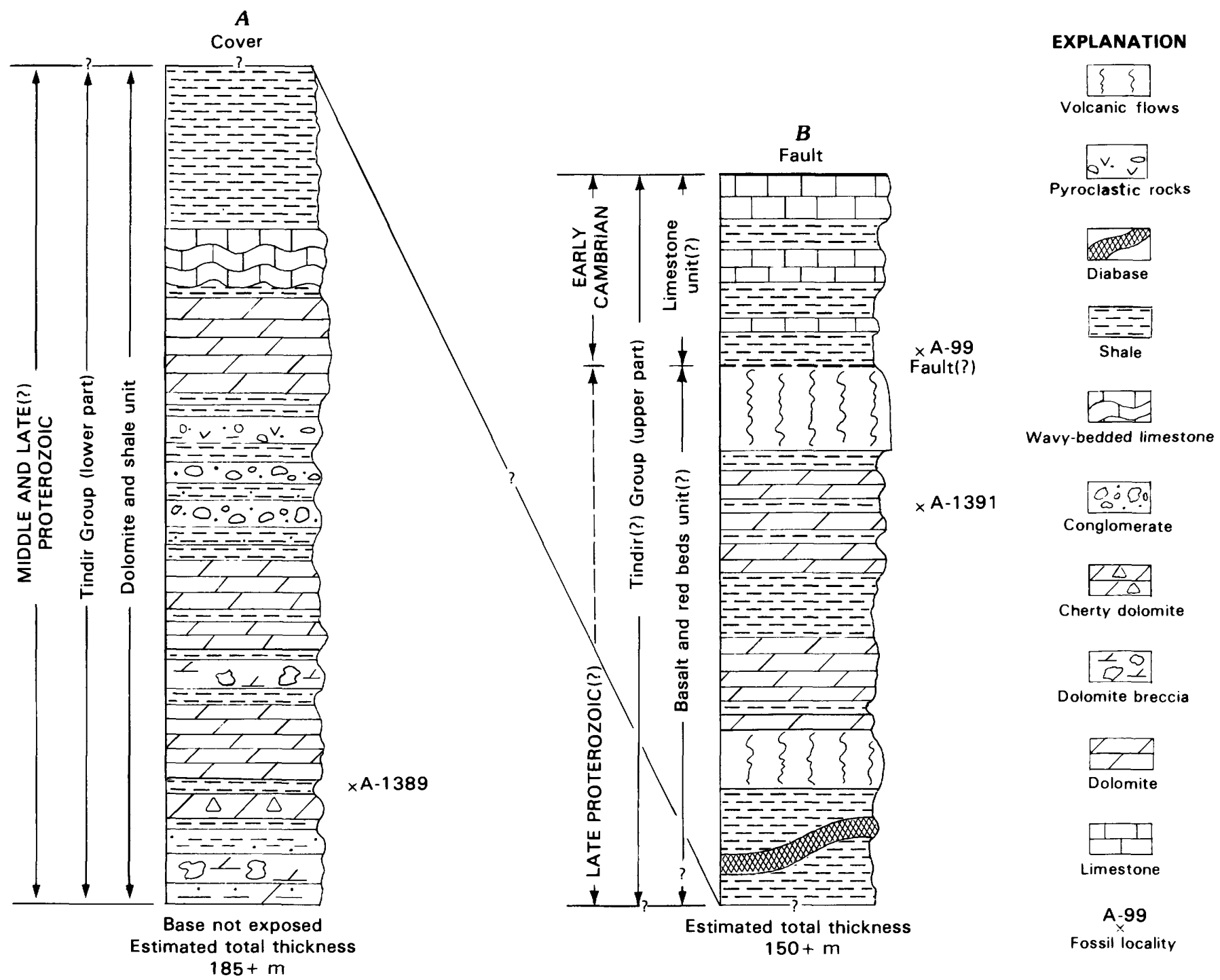

FIGURE 6.-Generalized stratigraphic column of the Tindir and Tindir(?) Group on west bank of Yukon River in Nation area, Alaska. $A$, Section exposed 3 to $6 \mathrm{~km}$ below Nation. $B$, Section exposed 12 to $15 \mathrm{~km}$ below Nation. 
microfossiliferous shales in the upper part of the section near the northern end of the bluff.

The east-west strike and high to overturned dips of the beds at Takoma Bluff persist to the east where exposure is extremely limited. Simple coccoid algae and acanthomorph acritarchs, described below and illustrated on plate 17 , occur at USGS locality $62 \mathrm{ABa} 2132$ about $17 \mathrm{~km}$ east of Takoma Bluff. Inflated spicules very similar to chancelloriids that occur in Washington Creek in the Nation area are present in a black shale sample collected by G.M. Young in 1979, and apparent arthropod material was found in associated chert collected by P. Brown in 1981 ; both come from the same exposures as 62ABa2132. Bedding-plane traces similar to the Late Proterozoic and Cambrian Oldhamia occur farther east in Edwards Creek (fig. 8; plate 18, fig. 1). Fossils found in the Woodchopper area are listed to the right.
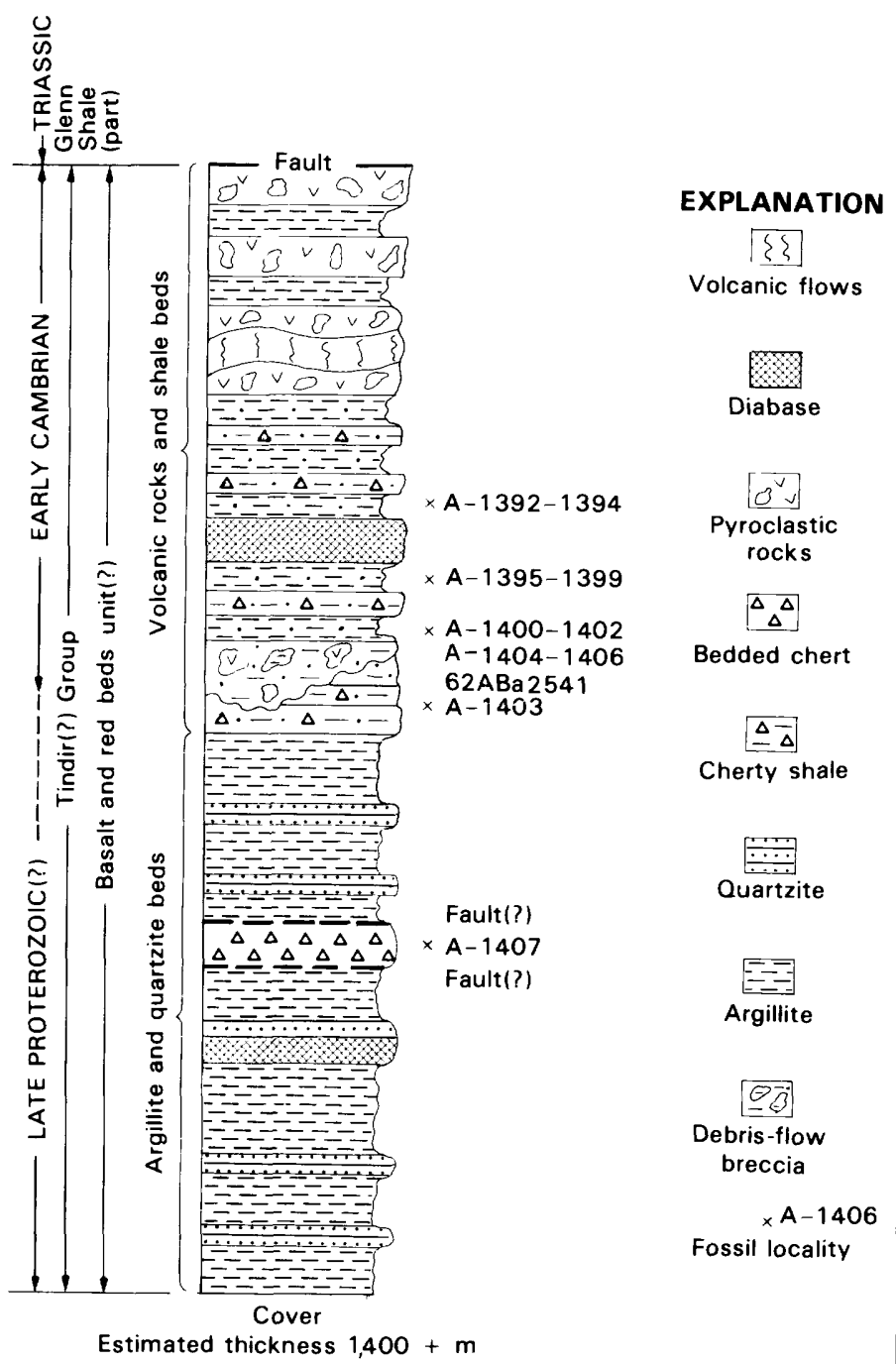

FIGURE 7.-Generalized stratigraphic column for Washington Creek exposures, western Nation area, Alaska.
Takoma Bluff

Undivided sedimentary rocks unit Sphaerocongregus variabilis Moorman 1974

Protista Incertae Sedis Type D

Protista Incertae Sedis Type E

Protista Incertae Sedis Type F

Cylindromyces septatus $\mathrm{n}$. gen. and $\mathrm{sp}$.

?Fungi, Oval Spore Type A

?Fungi, Oval Spore Type B

Planolites

Southeastern area

Undivided sedimentary rocks unit

Protista Incertae Sedis Type A

Protista Incertae Sedis Type B

Acritarcha, Acanthomorph Type A

Acritarcha, Acanthomorph Type B

?Oldhamia sp.

?Arthropod

\section{CORRELATION}

The presence in the Tatonduk and Nation areas of unquestioned Tindir Group rocks and of the same overlying Paleozoic formations provides reliable grounds for correlation between these two areas (fig. 9). Depositional relations between these areas and the Eagle area is, however, poorly understood and may reflect original separation followed by post-Paleozoic juxtaposition of the Eagle area rocks along the Dawson fault (Churkin and others, 1982). Although original depositional continuity of the Nation and Woodchopper areas can be interpreted on lithologic and stratigraphic grounds (Payne and Allison, 1981), the possibility that the Woodchopper area rocks occur in an allochthonous terrane has been proposed (Churkin and others, 1982).

With the exceptions of a widely known planktonic microfossil and distinctive inflated poriferan(?) spicules, none of the newly discovered microfossils occurs in more than one of the four exposure areas discussed in this paper. Correlation between these areas is based largely on lithologic and other criteria, augmented by interpreted age of available fossils. Middle and Late Proterozoic rocks appear to be present in all four areas, and microfossiliferous Cambrian rocks are now confirmed in the Tatonduk, Nation, and Woodchopper areas.

\section{PALEONTOLOGY}

Approximately 32 taxa, including bacteria, algae, fungi, protistans, and metazoans are recognized from the Tindir Group and rocks of similar ages examined for this study. Most of the fossils are from fine-grained clastic rocks in 
sequences of basinal character, and none occurs in a setting suggestive of a microbial mat community. Concentrated effort was made to locate fossils from the Eagle, Tatonduk River, Yukon River (near Nation), Washington Creek, and Takoma Bluff sections. Search for fossils from other areas of exposure was confined to occasional samples collected during geologic mapping in the early 1960 's by the U.S. Geological Survey or donated by petroleum or minerals exploration companies recently active in the area. These occasional samples represent a very small sampling of the Tindir Group and related rocks in terms of what is needed for even a representative overview of promising lithologies.

\section{SAMPLING PROCEDURES}

Field samples selected by the author generally were from dark, fine-grained sedimentary rocks although occasional coarser grained and lighter colored beds were also sampled. Sampling of every suitably fine-grained dark sediment in the Takoma Bluff and Washington Creek sections, in particular, is virtually impossible because there are thousands of such horizons in the former section and hundreds in the latter.

The most productive lithologies are dark, finely laminated siliceous shales; the paler gray or brown beds are less likely to contain fossils. Collection was not directed toward chert, which is very uncommon in the Tindir Group and rocks of similar age. Excellently preserved cells were found in limestone in very small siliceous patches, undetectable to the naked eye, and in laminated gray to black limestones and dolomites that might easily be rejected on the basis of field inspection. Within the Tindir red beds, rare tubular microfossils occur in thin dark horizons, and bacteria occur in red chert. Spicules in Washington Creek occur in both cherty shale and in laminated mudstone ranging in color from medium gray to black. Abundant, well-preserved plant cells and other fossils from Takoma Bluff occur in brittle gray beds exhibiting slaty cleavage and containing secondary biotite.
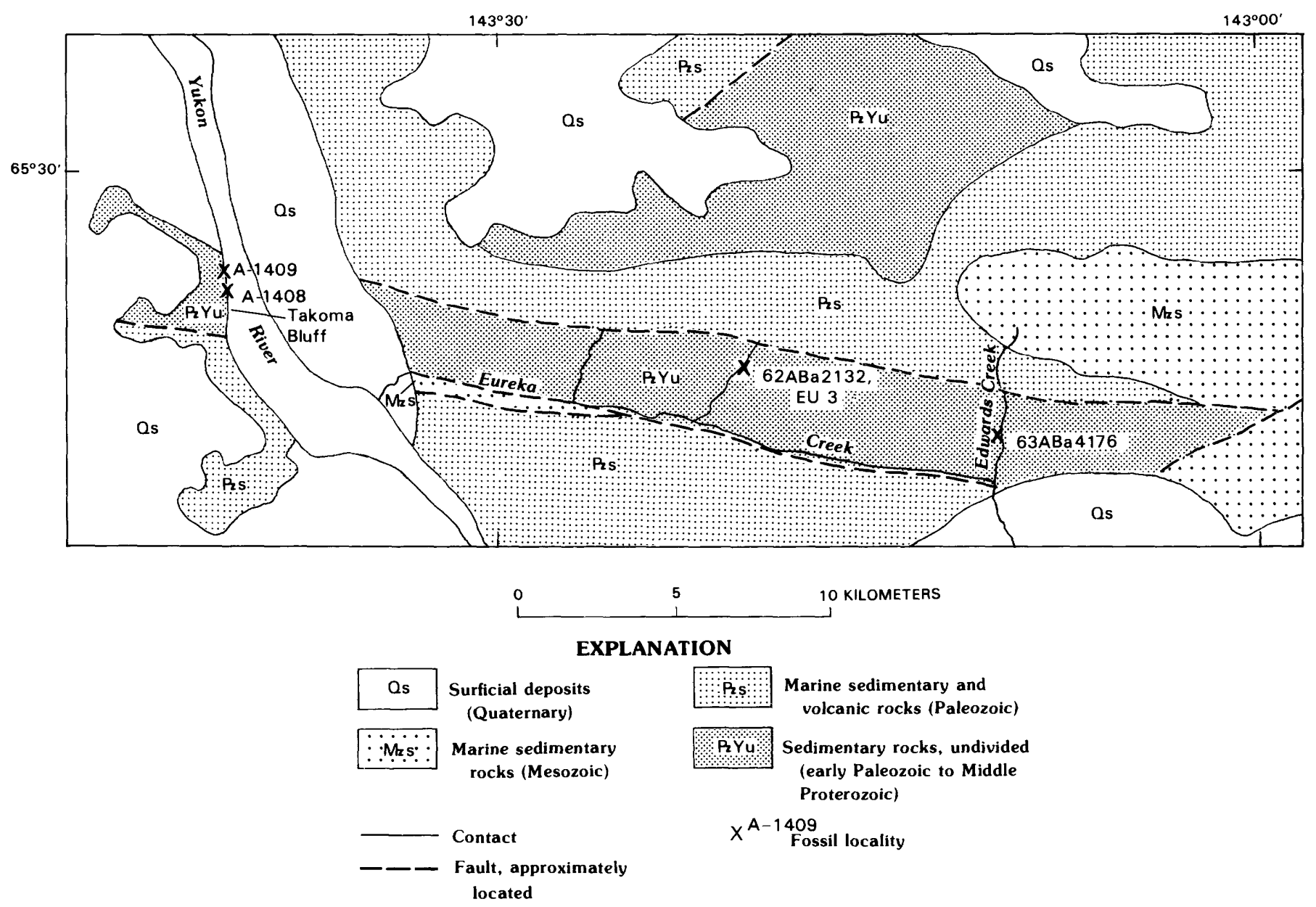

FIGURE 8.-Geologic map of southern part of Woodchopper area, Alaska (modified from Brabb and Churkin, 1969). 


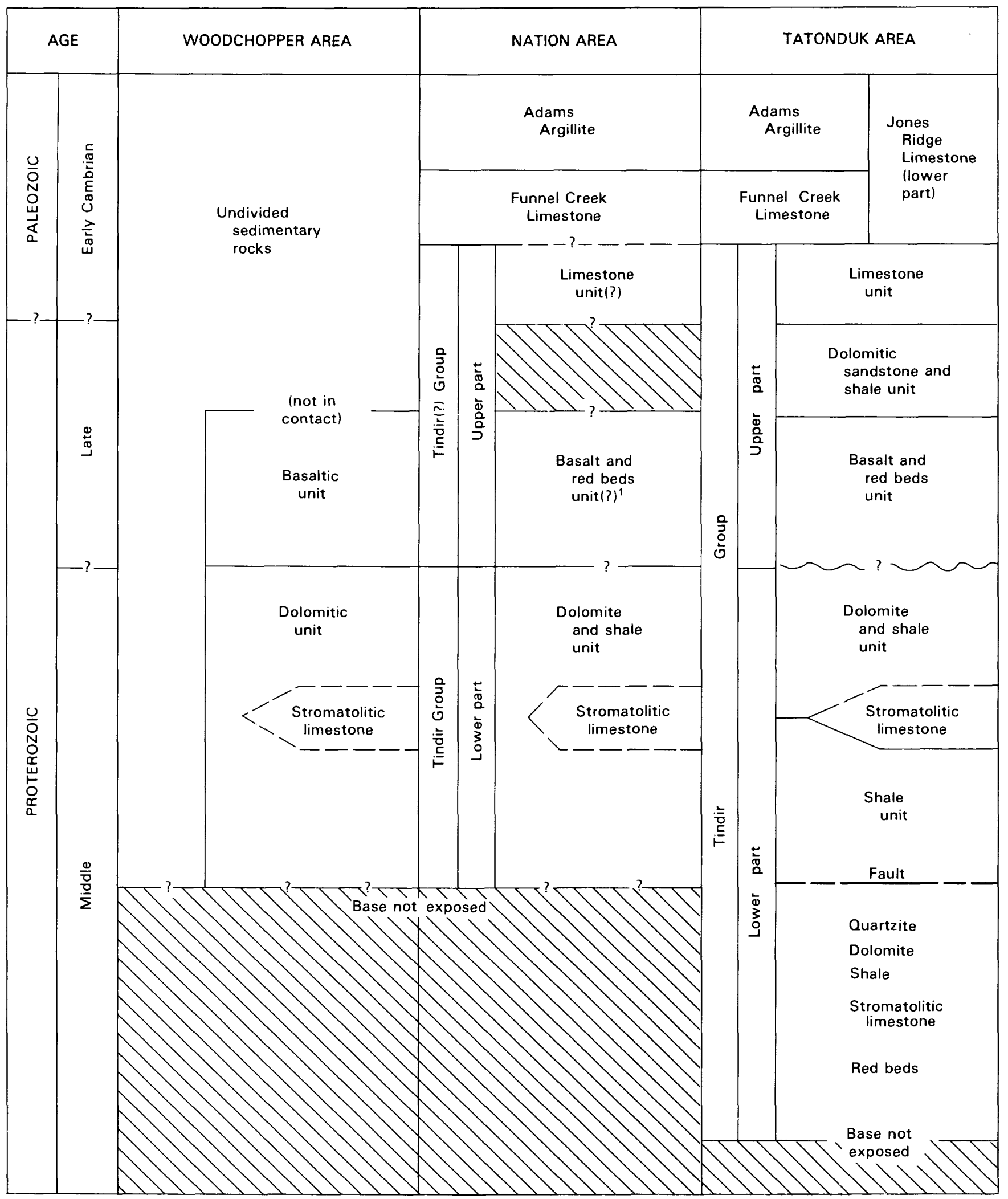

'Unit age in Washington Creek area is considered Late Proterozoic(?) and Early Cambrian

FiguRE 9.-Suggested correlation of Middle Proterozoic to Early Cambrian rocks of east-central Alaska. Wavy line, possible unconformity; diagonal pattern indicates lack of data for correlation. 


\section{LABORATORY PROCEDURES}

Preservational states of the microfossils described below are highly varied and are, therefore, discussed in detail under the separate headings for individual taxa. In general, the Takoma Bluff and Eagle area fossils are organically preserved. The Tatonduk area bacteria show no trace of original organic material, but the Tatonduk apparent fungal hyphae and cyanobacteria are not replaced. The Nation area organic-walled fossils are nearly all replaced with limonite or other minerals.

Most interpretations and descriptions of these fossils are based on examination of thin sections in transmitted light. The sections are preferentially cut parallel or slightly oblique to the bedding plane, commonly in the darker laminae. Samples containing organically preserved structures for which sufficient material was available were macerated at the Cloud Laboratory at the University of California at Santa Barbara, using standard palynological techniques. Fossils released during this process were examined and photographed by using scanning electron microscopy at the Santa Barbara laboratory and at the University of Alaska.

Several of the samples that were found to contain fossils, especially those collected by U.S. Geological Survey personnel and during initial wide sampling for this study, are of small size. Inasmuch as it was commonly not possible to collect again from these sites, thin-section preparation was preferred over maceration or other techniques. For this reason, some of the organically preserved fossils have thus far been studied only in thin section.

\section{INTERPRETATION}

Although the microbiotas reported from this study occur primarily in dark siliceous shales, they vary widely in abundance, manner of preservation, and constituents. Biotas from Washington Creek are, for example, clearly distinct from those at Takoma Bluff, and fossils from the Tatonduk River and the Eagle area are also distinctive. Considering the biota as a whole, in fact, only the coccoid forms here referred to Sphaerocongregus or Bavlinella occur in more than one of the five sections examined in detail, and only one type of fossil was found repeatedly in the rich Washington Creek section. Paleoenvironmental factors, inadvertent sampling bias, and the vagaries of preservation may be more responsible for this circumstance than difference in age of the biotas. The Tatonduk River and Washington Creek fossiliferous beds, which may be of similar age, are silica- and iron-rich basaltic sequences; however, the latter represents a low-energy basinal depositional environment and the former an apparently higher energy setting directly influenced by glacial as well as volcanic activity.

Eagle area microfossils also occur in laminated, silicarich dark shales in a volcanic sequence that is lithologically more similar to the Washington Creek fossiliferous beds than to the other sequences. However, rocks of the Eagle area are thought to be older than the Tindir(?) of the Washington Creek area and the Tindir of the Tatonduk River area, and they contain primarily coccoid fossils similar to cells from the dominantly carbonate sections at Takoma Bluff and near Nation but not known from the volcanic rocks and shale sequence at Washington Creek or on the Tatonduk River. On the other hand, fossiliferous shales from Washington Creek and Takoma Bluff have no taxa in common although both sequences are clearly basinal in character. In this case, however, the depositional settings differ; the former is a dominantly siliceous, volcanic and shaly sequence, and the latter is a nonvolcanic, primarily carbonate sequence.

The differing natures of the microbiotas from the Tindir area rocks suggest that even local age correlation based on the fossils is not necessarily reliable, a circumstance that should be borne in mind in attempts to discern age correlation, in any refined sense, of these Alaska fossils with occurrences elsewhere. In the few instances where the Alaskan fossils compare very closely with previously described taxa occurring elsewhere, the age relations, to the extent these are known, are discussed and evaluated. However, age equivalence even in these cases should not be presumed, particularly where based on forms that have apparent modern analogs. A stronger argument can be made for age correlations based on animal fossils such as the chancelloriid spicules, which represent an extinct group of unusual morphology and comparatively short duration. On the other hand, several studies have resulted in downward extensions of the age ranges of various Paleozoic animal groups (for example, see Matthews and Missarshevsky, 1975; Bloesser and others, 1977). These studies clearly show that, except where the earliest occurrence of a particular group is very reliably established, it is unwise to presume a Cambrian rather than a Late Proterozoic age.

\section{SAMPLE REPOSITORY}

Thin sections, permanent slide mounts of maceration residues, and samples prepared for scanning electron microscopy that contain specimens illustrated or otherwise cited in description of these fossils have been deposited at the U.S. National Museum, in the case of samples loaned by the U.S. Geological Survey, and at the University of Alaska Museum, in the case of samples collected by and for the author. The permanent repositories 
for fossiliferous samples shown on the plates are cited in appendix $\mathrm{C} ; \mathrm{X}$ and $\mathrm{Y}$ coordinates indicate the fossil locations on the thin sections. These locations can be related to $\mathrm{X}$ and $\mathrm{Y}$ coordinates given in appendix $\mathrm{C}$ for the lower left corners of the cover slips.

\section{SYSTEMATIC PALEONTOLOGY}

\author{
BACTERIA \\ Genus EOASTRION Barghoorn and others, 1965
}

?Eoastrion sp.

Plate 1, figures $1-8$

Description.-Branching, thread-like structures with individual filaments typically 0.6 to $1 \mu \mathrm{m}$ in diameter, as long as $23 \mu \mathrm{m}$, straight or bent to curved; filaments commonly occur in simple to complex radiating bodies 5 to $250 \mu \mathrm{m}$ in diameter.

Discussion.-Reddish-amber colored, thready structures are extremely abundant in a laminated dark-red chert in the Tatonduk River section. They are widely dispersed in the matrix and display a variety of morphotypes. The simplest are short, unbranched filaments that may have a more or less spherical body about $2 \mu \mathrm{m}$ in diameter at one end. Others have two or more filaments radiating from a small central body, and occasional specimens have much larger dark central areas with numerous radiating filaments; these resemble trichospherical bacterial colonies. Filaments tend to be straight or bent but may be gently to strongly curved.

The matrix of this chert, as seen in transmitted light, consists of pale yellow silica with very abundant, fairly evenly dispersed, small subangular bodies that are indistinguishable in color and texture from the threads. These bodies may represent clusters of cocci or abiogenic concentrations of mineral grains. Occasional larger, typically rounded areas of yellowish material surrounding darker central patches do not contain filaments or clumps of cocci(?) and appear to represent post-depositional concentrations of different mineral phases. The apparently bestpreserved specimens occur in paler chert patches in which there appears to be little or no overgrowth on the filaments (pl. 1, figs. 1, 2). The typically angular margins of these paler areas suggest they are clasts that have undergone essentially no transport. Here the filaments are easily seen and are composed of closely spaced, more or less spherical bodies 0.6 to $0.8 \mu \mathrm{m}$ in diameter arranged in uniseriate chains that may taper slightly distally. Morphotypes include single and radiating filaments as well as very small, clustered, subrounded grains of sizes con- sistent with the diameter of the filaments, which suggests that the clustered grains are dispersed cocci. Outside the clear patches, the filaments are coated to varying degrees with iron and (or) manganese minerals, in some cases to the extent that a trichospherical colony form is not distinguishable, and they appear as globose to irregular dense masses with occasional filaments protruding from the periphery.

Generally similar structures have been reported from shallow-water stromatolitic cherts in the approximately 2.0-billion-year-old Gunflint Chert in Ontario, Canada; these were placed in the paleogenus Eoastrion by Barghoorn and others (1965). Detailed studies of forms interpreted to be indistinguishable from the Gunflint Eoastrion were made by Kline (1975) on fossils from the 1.6-billion-year-old Paradise Creek Formation of Australia, also a shallow-water stromatolitic unit. Kline concluded that Eoastrion represents a budding bacterium that is morphologically most comparable to the modern iron- and manganese-sequestering Metallogenium. This genus and related modern genera occurring in northern Europe have been described in detail by Perfil'ev and others (1965). According to these authors, Metallogenium occurs in streams and lakes but is more common on or in lake-bottom muds, where it occupies a narrow microzone a few millimeters below the sediment-water interface. It is sensitive to oxidation-reduction conditions, which control the degree to which manganese oxide encrusts the trichospherical colonies. In the lower part of the zone, where reducing conditions are dominant, the colonies exhibit little or no encrustation. At increasingly higher levels, and with increasing oxidation, the colonies become increasingly coated until they appear as lobate radial forms.

The Alaska structures, although generally similar to Metallogenium, tend to have straighter filaments in the trichospherical colonies than do those illustrated by Perfil'ev and others (1965, figs. 7, 8); however, specimens of Eoastrion illustrated by Kline (1975, pls. 2 and 3$)$ include straight, rigid-looking filaments from both the Paradise Creek and Gunflint biotas. The Alaska sample also contains large, orange-colored, typically round patches of less obviously radiating structures (pl. 1, figs. $3,4)$ that may contain a distinct, round, dark central body. These patches are faintly reminiscent of morphotypes illustrated by Perfil'ev and others (1965) as zooglealbranched micro-colonies of Metallogenium (their figs. $14-1 \mathrm{a},-2 \mathrm{a},-5)$ and of the primarily manganesesequestering Caulococcus (their figs. 21-1 to $-4,22-5 \mathrm{a}$, $-6 a,-7 a)$.

Occurrence.-A-1388, basalt and red beds unit, Tatonduk River. 


\section{CYANOBACTERIA \\ ?Order PLEUROCAPSALES}

Genus SPHAEROCONGREGUS Moorman, 1974

Several biotas from the Tindir and Tindir(?) Group and related rocks in east-central Alaska include fossils referable to the paleogenus Sphaerocongregus (Moorman, 1974) or to Bavlinella (Shepeleva, 1962). Sphaerocongregus is synonymized by many workers with the earlier described Bavlinella because one of the several morphotypes included by Moorman in Sphaerocongregus is a multiunit sphere entirely similar to Bavlinella. Many biotas in which Bavlinella occurs are not reported, or not interpreted, to contain the other morphotypes described by Moorman (1974). However, two of the six Alaska biotas that contain comparable multiunit spheres include all of the additional morphotypes described by Moorman, and the other four include at least one morphotype in addition to the multiunits. Although nonpreservation of the range of Sphaerocongregus morphotypes in Bavlinellacontaining biotas may justify synonymizing the former under the latter, other explanations are possible. For this reason, both genera are recognized here, and the problem is further discussed below. Of the six Alaska occurrences referred to these genera, two are from the undivided sedimentary rocks unit at Takoma Bluff, where they occur with other species. The other occurrences, all in monospecific biotas, include one each from the dolomite and shale unit of the lower part of the Tindir and the limestone unit(?) of the upper part of the Tindir(?) in the Nation area and one each from the greenstone unit and the quartzite and argillite unit near Eagle.

\section{Sphaerocongregus variabilis Moorman, 1974}

Plate 12, figure 10; plate 13 , figures 9 , 10; plate 14 , figures 1,2 ; plate 15 , figures $1-8$; plate 16 , figures $1-4,9-12$

Discussion.-Fossil material that is referable to Sphaerocongregus variabilis is well preserved as pale- to darkbrown, translucent organic-walled structures in black siliceous shale from localities A-1408 and A-1409 at Takoma Bluff. No mineral replacement of the cell walls is visible, but the larger organic-walled cells and denser cell masses are commonly bordered on two opposite sides by transparent bands of phyllosilicates. These bands have a definite orientation that apparently reflects shear pressures resulting in incipient slaty cleavage in the enclosing shaly beds. Silicate sheets in all of the bands in a given thin section lie more or less parallel to one another, the shape and width of the band being related to the shape and size of the specimen and to its orientation with respect to the direction of shear of the rock.
These silicate bands occur only in association with larger organic-walled cells, cell masses, and occasional dense patches of degraded indeterminate biologic material, so they may reflect special chemical microenvironmental conditions directly related to postmortem breakdown of cell contents. An alternative interpretation is that at the time of shearing of these beds, the larger contained organicwalled fossils responded to pressure such that minute, preferentially oriented fractures were produced that later filled with silicates. Size of the fossil cannot be the only factor controlling the presence or absence of the silicate bands because equally large, undoubtedly biogenic structures from A-1409, described below as Protista Incertae Sedis Type G and suggested to be of protozoan affinity, do not have silicate bands.

Several growth forms of Sphaerocongregus variabilis are present in the abundantly fossiliferous shales at A-1408 and A-1409. All forms are variations of coccoidal morphology: (1) small, smooth, single cocci; (2) gradationally larger, rough-surfaced spheres that occur singly, attached to one another in single-file strands, associated with similar cells in large elongate pseudofilamentous clones two to three cells wide and tens of cells long, or, rarely as nonseriate, tightly packed masses; and (3) endosporangia in the form of solidly packed, spheroidal masses of uniform coccoidal spores (fig. 10).

Sizes of 40 random individuals of each fossil type, except the larger cocci, were measured under oil-immersion light microscopy $(100 \times 12.5)$. The larger cocci are interpreted as mature vegetative cells, and the pseudofilamentous chains may be the result of successive asymmetric vegetative divisions. The size range of cells in pseudofilaments was obtained by measuring 33 members of one of the better preserved specimens. The best preserved of the 11 pseudofilaments seen is $130 \mu \mathrm{m}$ long and $19 \mu \mathrm{m}$ wide, and it contains at least 42 cells (pl. 15, figs. 1, 2).

The smaller-sized cells with simple coccoidal structure range from 1.7 to $4.1 \mu \mathrm{m}$ in diameter (mean $2.9 \mu \mathrm{m}$ ) and are interpreted as released spores not yet matured into vegetative cells. Even smaller apparent cells are present, but these structures could not be definitely distinguished as biogenic. Singly occurring spheres smaller than $1.5 \mu \mathrm{m}$ were not included in measurement of cells in this species. The resulting discrepancy between the size range of smaller, simple cells and that of spores measured in the endosporangia may not reflect the original complete cellsize range.

Larger cocci ranging from 2.8 to $10.8 \mu \mathrm{m}$ in diameter (typically 6 to $8 \mu \mathrm{m}$ ) are the most numerous growth form seen. These cells occur singly or, less frequently, attached to similar cells of the same or smaller size along a distinct planar surface; the resulting associations range from 


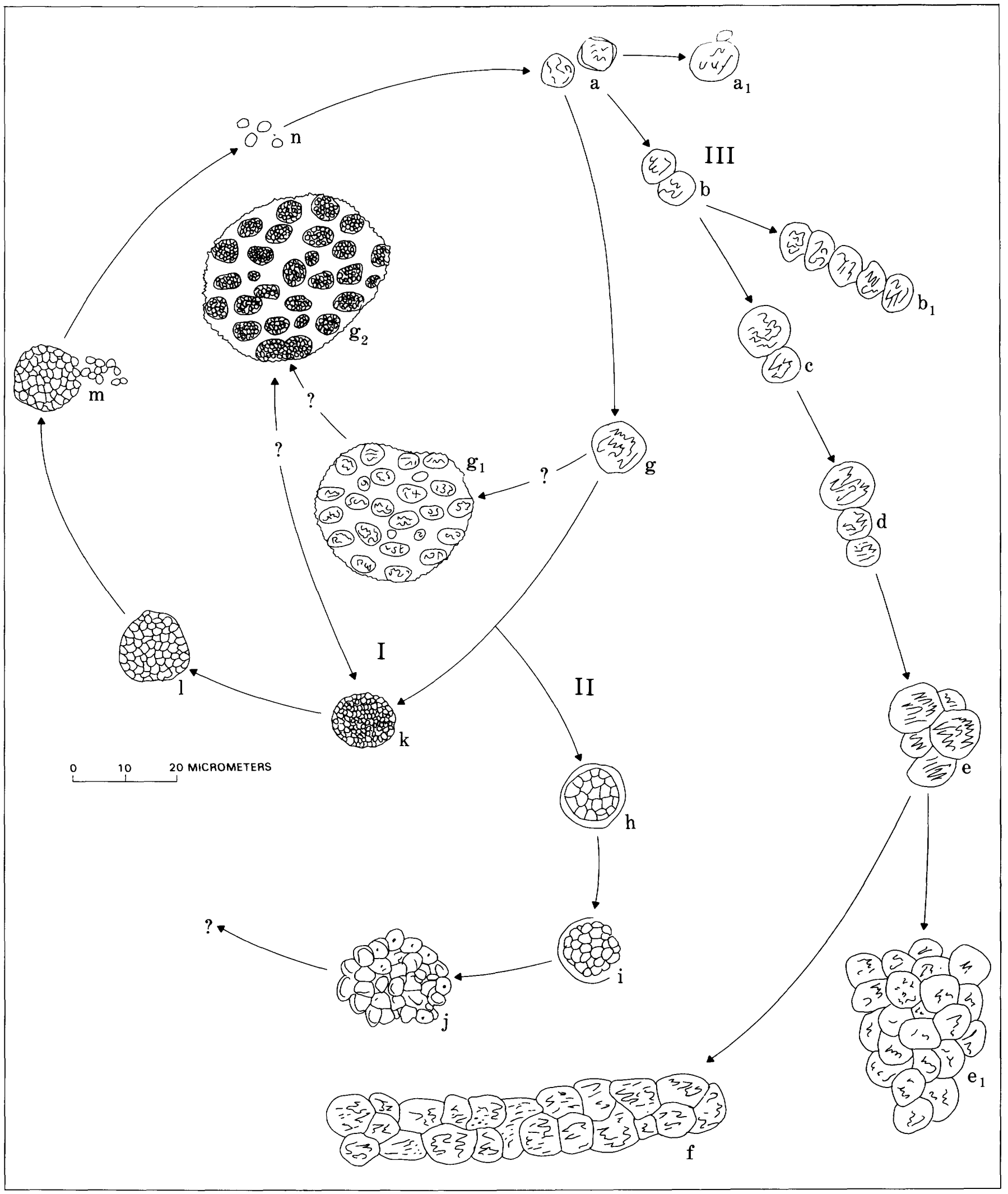

FIGURE 10.-Hypothetical growth cycle for Sphaerocongregus variabilis, modified from Moorman (1974). I, Ordinary endospore formation resulting in thin-walled multiunits and release of small-size spores. II, "Nannocyte" formation and resulting clone of larger cells. III, Growth of unicell chain or clump by subequal vegetative division.
Morphotypes $a_{1}, b_{1}, e_{1}$, and $g_{2}$, present in Alaska material, were not reported by Moorman. Morphotype $\mathrm{g}_{1}$, not reported by Moorman or clearly identified in Alaska material, represents an alternative hypothetical direct stage between $\mathrm{g}$ and $\mathrm{g}_{2}$. Stages $\mathrm{g}_{1}$ and $\mathrm{g}_{2}$ shown at onethird magnification relative to cells shown in other morphotypes. 
single-file chains a few cells long to large, linear, tightly packed masses of various-sized cells (pl. 15, figs. 1, 2, 7, 8). A few examples of nonseriate, tightly packed coccoids are also present at A-1409 (pl. 15, fig. 3; pl. 16, fig. 7).

Solid spheroidal bodies of isodiametric coccoids, interpreted as cyanophyte endosporangia (Moorman, 1974), are abundant. Entire sporangia range from 4.8 to $19.3 \mu \mathrm{m}$ in diameter (mean $10 \mu \mathrm{m}$ ), and individual spores range from 0.5 to $2 \mu \mathrm{m}$ in diameter (average $1.2 \mu \mathrm{m}$ ). In general, spore size increases with size of the sporangia in which they occur. Dense packing within the sporangia tends to give some of the spores a subangular shape.

Sporangia may occur as groupings of dozens of individuals or may be randomly scattered in the matrix. One oval mass about $1 \mathrm{~mm}$ wide and $1.5 \mathrm{~mm}$ long contains about 100 more-or-less intact sporangia and many empty and broken ones. Thousands of released spores, quite closely packed in the matrix around the sporangia in this mass, are commonly 2 to $2.5 \mu \mathrm{m}$ in diameter. Less abundant, more widely spaced unicells ranging from 3 to $5 \mu \mathrm{m}$, also dispersed in the mass, and perhaps some of the less well preserved empty spheres of somewhat larger size are interpreted as maturing cells.

Cell masses appear to reflect random depositional factors at A-1409, but at A-1408 those containing a high percentage of sporangia tend to be somewhat confined in what may have been a fairly cohesive mucilaginous medium (fig. 10, morphotype $\mathrm{g}_{2}$ ). Outlines of these masses vary in shape but tend to have a rounded, in some cases quite discrete, margin. These groupings are very distinctive and suggest an additional growth phase.

The biota at A-1408 also includes curving, cell-filled tubular structures, described below as Cylindromyces septatus, that may be fungal in origin. These contain unicells indistinguishable in appearance from the unicells interpreted as belonging to Sphaerocongregus. The relative contribution from Cylindromyces septatus and Sphaerocongregus to the matrix cell population in A-1408 is, therefore, not certain. Most of the several dozen tubular Cylindromyces structures seen are empty; however, where cells remain in the tubes they are no less than $4 \mu \mathrm{m}$ in diameter and do not include identifiable multiunit structures.

An unusual phenomenon is present in some of the coccoid cells in the matrix at A-1409. Occasional, randomly distributed specimens contain bright, clear round areas that do not appear to be membrane-bounded (pl. 16, figs. $1,2)$. Under polarized light these areas are revealed to be isotropic and may be gas, oil, water, or some other fluid. Although the enclosing cells at A-1409 are less well preserved, these fluid(?) inclusions are entirely similar in relative diameter and appearance to fluid inclusions in well-preserved coccoid fungal cells in fractures in red chert in the basalt and red beds unit of the Tindir on the Tatonduk River. The fungi are clearly younger than the chert because they invariably occupy silica-filled fractures, in which they are extremely well preserved as pale-amber structures, whereas the chert itself contains only poorly preserved, replaced bacteria. When these fungi entered the fractures and became silicified is not certain, but the form present is referable to modern terrestrial genera that can be expected in Alaskan perifluvial settings (Patrick Flanagan, oral commun., 1978). Similarity between the appearance of fluid inclusions in these specimens and the bright spots in the cells at A-1409 does not allow presumption that the same substance is present in both, but the possibility that the cells at A-1409 contain fluid, as is probable for the Tatonduk River occurrence, can at least be considered.

Occurrence.-A-1408 and A-1409, undivided sedimentary rocks unit, Takoma Bluff, Woodchopper area.

\section{?Sphaerocongregus sp.}

Discussion.-Poorly preserved organic-walled unicells, and apparently less abundant multiunits, are present in an organic-rich, dark-gray siliceous silty shale in the quartzite and argillite unit near Eagle. Although less distinctive than those in the Takoma Bluff Sphaerocongregus biotas, bands of phyllosilicates on opposite sides of larger cells are also present in this shale and, as at Takoma Bluff, the cells do not contain pyrite. Most of the fossils are preserved as finely granular, dark-brown, thinwalled, isolated cells or small groups of cells 2 to $10 \mu \mathrm{m}$ in diameter; occasional specimens appear smooth-walled and more or less hyaline. Structures clearly identifiable as multiunits are very rare; however, some of the poorly preserved, apparently empty cells have convexly scalloped margins and could have been endosporangia. Specimens that are intact range in diameter from 5 to $8 \mu \mathrm{m}$ and have subunits slightly less than $1 \mu \mathrm{m}$ in size. Cell associations identified as cycle II and as cycle III stage f (see fig. 10) were not observed, but cycle III stages a through e are present. The large masses of unicells present at Takoma Bluff at A-1409 and A-1408, and the dense clumps of multiunits at A-1409 (shown as cycle I, $\mathrm{g}_{2}$ ), were not observed in the Eagle material. No other types of fossils were found in the enclosing shale, which differs from other Alaskan rocks with similar fossils in that it contains abundant volcanic shards.

Occurrence.-60ABa971A, quartzite and argillite unit, near Eagle.

\section{Genus BAVLINELLA Shepeleva, 1962}

Bavlinella sp.

Nation area

Discussion.-Spherical unicells 4 to $11 \mu \mathrm{m}$ in diameter (typically 4 to $6 \mu \mathrm{m}$ ) and spherical multiunits 5 to $16 \mu \mathrm{m}$ 
in diameter are sparse in black shales interbedded with medium-gray, finely laminated dolomitic sandstone in the western Nation area. These specimens were described by Moorman (in Allison and Moorman, 1973), who interpreted that they include two types of spherical multiunits. The more common type is 5 to $9 \mu \mathrm{m}$ in diameter, made up of cells 0.8 to $1.2 \mu \mathrm{m}$ diameter. A less common type is 10 to $16 \mu \mathrm{m}$ in diameter, made up of cells 1.3 to $2 \mu \mathrm{m}$ diameter. Preservation in this biota ranges from replacement by a transparent yellow-orange limonitic(?) mineral without pyrite to partial or complete replacement by pyrite. Similarity of the pyrite-replaced multiunits described from these samples to pyrite framboids led Kalliokoski (1974) to interpret a nonbiologic origin for this Tindir material. However, maceration of the samples, including treatment with nitric acid to remove the pyrite, yielded honeycomb-like membranous structures (Allison and Moorman 1973, fig. 1B) entirely comparable to the undoubtedly biogenic Sphaerocongregus multiunits in macerations of A-1408 (pl. 14, figs. 1, 2), which do not contain pyrite. Later work by Vidal $(1979$, p. 19) addressed this problem and pointed up the importance of surface textural features in recognition of a biogenic origin for structures of this type.

The size ranges of unicells and multiunits in A-1389 and A-1391 fall within those for S. variabilis from Takoma Bluff. However, because the Nation area fossils are poorly preserved and include no cycle III morphotypes they are referred to the genus Bavlinella.

Occurrence.-A-1391, basalt and red beds unit(?); A-99, limestone unit(?); and A-1389, dolomite and shale unit, Nation area. The rocks at A-1389, suggested earlier by Allison and Moorman (1973) to represent either the dolomitic sandstone and shale unit of the upper part of the Tindir or the dolomite and shale unit of the lower part of the Tindir, have now been confirmed to be the latter.

\section{Bavlinella sp.}

Plate 2, figures 4, 5

\section{Eagle area}

Discussion.-Spherical unicellular and multiunit microfossils are abundant in dark shale in the greenstone unit near Eagle. These are preserved as very pale to mediumbrown, organic-walled hyaline structures in the lighter bands of a very finely laminated black, siliceous shale. Darker and lighter bands are 2 to $10 \mathrm{~mm}$ thick; the darker layers are made up of laminae 10 to $20 \mu \mathrm{m}$ thick. Fossils may be present also in the dark layers but are not identifiable because of the extremely dense nature of this primarily carbonaceous material. Some of the multiunits are slightly elongate parallel to the bedding. These cells have commonly burst open and have individual subunits somewhat released from the typical compact construction.
They could represent preserved natural spore release or degradation of multiunits immediately before silicification. Subunits in these specimens tend to have a subangular shape, but many of the multiunits and virtually all of the unicells display a spherical shape. The pyrite or other iron minerals associated with the Nation area Bavlinella are absent in this material.

Unicells vary from 3 to $9 \mu \mathrm{m}$ in diameter; 75 percent of the cells are 6 to $9 \mu \mathrm{m}$ in diameter. Cell walls are thin, hyaline, and commonly slightly wrinkled but without evident original surface texture. Occasional specimens have slightly thicker, more-or-less granular-appearing walls that may be a preservational artifact. Although random small clumps of four to six cells are present, these fossils generally occur as single, well-spaced individuals. No cells in the process of fission or aligned in even short chains were observed; however, two specimens, each about $9 \mu \mathrm{m}$ in diameter, have small $(3.8 \mu \mathrm{m})$ rounded protuberances that could reflect budding or incomplete separation following highly unequal vegetative division.

Spherical multiunit structures appear to be of two types. One type ranges from 10.5 to $16.3 \mu \mathrm{m}$ in diameter and is made up of units 1.2 to $2.1 \mu \mathrm{m}$ in size. The other ranges from 5.7 to $9.2 \mu \mathrm{m}$ in diameter and is made up of units 0.5 to $0.9 \mu \mathrm{m}$ in diameter. Subunit size in the first type increases with increasing sporangium(?) size, but apparently this is not the case in the second type.

The sizes of both unicells and multiunits in this biota fall within the ranges for similar morphotypes of Sphaerocongregus and Bavlinella from Takoma Bluff and the Nation area. However, reproductive modes documented for fossils from the Eagle quartzite and argillite unit and from Takoma Bluff are not convincingly identical to these from the Eagle greenstone unit and the Nation area. In the Eagle material from the greenstone unit (63AGs253A), reproduction by equal fission has not been seen, but rare production of small daughter cells is apparently present, whereas in the Takoma Bluff biotas both processes are well represented. Vegetative reproduction resulting in multiseriate chains of distinctive morphology is clearly present in the Takoma Bluff material, and cell associations approaching this morphotype are preserved in the quartzite and argillite unit $(60 \mathrm{ABa} 971 \mathrm{~A})$ near Eagle, but there is no hint of these structures among the relatively well preserved and very abundant fossils at 63AGs253A. Moreover, the generally increasing size of subunits with increasing size of multiunits at Takoma Bluff is not apparent in this Eagle area biota, although multiunits in the latter area all fit within the size ranges and growth phases depicted by Moorman (1974) as cycles I and II (see fig. 10). Similarity between the biotas at $63 \mathrm{AGs} 253 \mathrm{~A}$ and the Nation occurrences is suggested by the absence in all of growth phases $b, d$, e, and $f$ of cycle III. 
Occurrence.-63AGs253A, greenstone unit of Brabb and Churkin (1965), Eagle area.

\section{Sphaerocongregus and Bavlinella}

\section{Biologic Affinity}

Sphaerocongregus variabilis from the Hector Formation was interpreted by Moorman (1974) as a planktonic species and in comparison with the modern endosporulating Pleurocapsa fuliginosa(?) as described by Beck (1963). The latter is primarily lithophytic or epiphytic but has planktonic stages within its complex growth cycle. As pointed out by Moorman (1974, p. 528), there are similar species of entirely planktonic habit for which complete growth cycles are not as yet sufficiently known to support their full comparison with $S$. variabilis. Moorman (1974) favored affinity of the Hector fossils with the Pleurocapsales, but she pointed out then, and subsequently (in Cloud and others, 1975), that modern cyanophytes from the Chroococcales and Chaemosiphonales also include suitable endosporulating analogs. Work by Rippka and others (1979) favors referral of $S$. variabilis to the Pleurocapsales whereas Mansuy and Vidal (1983) favor assignment to the Chroococcales.

\section{Age}

Sphaerocongregus from the Hector Formation was interpreted by Moorman (1974) to be of Late Proterozoic age. Bavlinella-like fossils, although commonly regarded as restricted to Late Proterozoic and Early Cambrian age rocks, may prove to range into the later Paleozoic and Mesozoic (Hofmann, 1984). Interpreted ages of the several Alaska occurrences are considered separately here because their host rocks differ geographically, stratigraphically, and lithologically.

The Eagle representatives of Bavlinella sp. occur in a volcanic-rich unit in a fault-bounded wedge of sedimentary, volcanic, and metamorphic rocks that continue eastward into Canada where they are currently accorded a Late Proterozoic (=lower part of Windermere Group) age. Earlier thought to be perhaps as old as 850 m.y., the basal part of the Windermere is now thought to be no older than 728 m.y. (Evenchick and others, 1984). If the Eagle area rocks are age-equivalent to the basal part of the Windermere, the fossils from 63AGs253A, together with those at $\mathrm{A}-1386$ and $60 \mathrm{ABa} 917 \mathrm{~A}$, are the oldest microfossils known from east-central Alaska. However, D. Tempelman-Kluit (written commun., 1981) reports the presence of arenaceous microfossils no older than Ordovician in exposures to the east that are currently assigned to the same inclusive map unit (Green, 1972). The presence of worm traces in the quartzite and argillite unit near Eagle indicates that these rocks are no older than about 650 m.y. The Eagle greenstone unit, however, may not be the same age. Volcanic rocks continuous to the east were also recognized as a separate map unit, possibly younger than associated rocks that are correlative with the Eagle quartzite and argillite unit (Green, 1972).

The Nation area fossils from A-1389 occur in the dolomite and shale unit of the lower part of the Tindir, of Middle and Late(?) Proterozoic age. Fossils from A-1391 occur in an apparently overlying volcanic sequence interpreted to be of Late Proterozoic age. Fossils from A-99 occur in dark limestones and shales that are herein referred to the limestone unit(?) of the upper part of the Tindir(?), considered to be Early Cambrian rather than Proterozoic in age.

Age of the Takoma Bluff fossiliferous shales is more uncertain. It is tempting to correlate these occurrences closely with the Hector fossil-bearing sediments on the basis of the virtual identity between Sphaerocongregus variabilis in the Hector shales and at Takoma Bluff. The Hector fossiliferous shales lie stratigraphically above the Toby Conglomerate, interpreted by some workers (Ziegler, 1959; Gabrielse, 1967; Aalto, 1971) as primary or reworked till reflecting Late Proterozoic glaciation, and lie unconformably beneath the Lower Cambrian St. Piran Quartzite. An approximate age of 700 m.y. was conjectured by Moorman (1974) for the Hector fossiliferous shales. Thus a close correlation between the Hector fossils and the Takoma Bluff Sphaerocongregus biotas would indicate a Late Proterozoic age for the latter. However, as discussed in Payne and Allison (1981), a near-Cambrian age, closer to $600 \mathrm{~m} . \mathrm{y}$. than to $700 \mathrm{~m} . \mathrm{y}$., is more likely for the Tindir glaciogenic rocks. Presence of Planoliteslike traces a short distance conformably upsection from the Takoma Bluff Sphaerocongregus is inconsistent with an age greater than about $650 \mathrm{~m} . \mathrm{y}$. Co-occurrence of Bavlinella with micrhystid and baltisphaerid acritarchs in the Early Cambrian of Norway (Vidal, 1979) may provide a useful age indication for the Takoma Bluff biotas in view of the presence of similar acritarchs, ?Oldhamia, and an apparently shelled arthropod more or less along strike to the east.

\section{Order NOSTOCALES \\ Family NOSTOCACEAE Kutzing, 1843}

Genus PALEONOSTOCALIA n. gen.

Type species.-Paleonostocalia irregularia $\mathrm{n}$. sp.

Diagnosis.-Filaments unbranched, uniseriate, typically composed of spherical cells irregularly interspersed singly or in series with elongate rod-shaped hormogones(?) (and possible akinetes); spherical and elongate cellular units commonly well separated; sheath indistinct, detailed structure unknown; filaments typically straight, 8 to $12 \mu \mathrm{m}$ wide, as long as $640 \mu \mathrm{m}$ (incomplete); terminal 
structure unknown; hormogones(?) composed of an uncertain number of cells, crosswalls not observed; akinetes, if present, indistinguishable from hormogones; heterocysts not identified.

Paleonostocalia irregularia n. sp.

Plate 3, figures 1-7; plate 4, figures 1-4

Diagnosis.-Same as for genus. Spherical cells 4.9 to $11.7 \mu \mathrm{m}$ in diameter (77 cells measured); hormogones(?) (and possible akinetes) range from 9.8 to $29.4 \mu \mathrm{m}$ in length and 2.9 to $7.8 \mu \mathrm{m}$ in width ( 66 cells measured). Of the 77 spheres measured, 51 are 7 to $9 \mu \mathrm{m}$ in diameter; of 66 elongate cells measured, 45 are 4 to $5 \mu \mathrm{m}$ wide and 15 to $24 \mu \mathrm{m}$ long.

Type material.-62ABa2541-1, one of two fossilcontaining thin sections cut from a single thin piece of rock.

Discussion.-All material referred to this species, which occurs in many horizons in the Washington Creek section, is completely replaced with limonite (or goethite) and (or) pyrite. Description is based entirely on appearance of the fossils in thin section.

Variety in arrangement of spherical and rod-shaped structures in this material is notable. Filaments, none of which is probably complete, may be made up entirely of spheres or entirely of rods, but most have an irregular arrangement of both morphotypes. However, recognition of separate species reflecting these three arrangements appears unwarranted on the basis of available material because there are no consistent differences in cell shapes, surface characteristics, or preservation. The three types show an equal tendency to be straight rather than curved and to have adjacent spherical and (or) rod structures similarly separated from one another within the filaments. Lack of recognizable morphologic differences among the spheres and rods, and lack of consistent size classes among the rods, precludes confident identification of akinetes and heterocysts, although one or both may have been present in some of the filaments. Should betterpreserved material become available, identification of these structures, and separation into more than one taxon, might be possible.

A straight filamentous habit is clearly dominant. The few specimens that are not straight are very gently curved, and specimens suggesting twisting or folding of the filaments are not common. The markedly linear appearance may indicate that the sheath was not very flexible or that these organisms grew on the bottom or were in some manner undisturbed by current action during burial. No preferential arrangement of the filaments within the sediment layers is evident. Filaments lie at various angles within single layers and are not concentrated in masses or particular areas as would be expected if current action had controlled postmortem distribution.
Although terminal structures have not been identified and some breakage is clearly present, lack of contortion of filaments, together with their well-spaced distribution in the sediment, is consistent with an interpretation that they are preserved nearly in the position in which they fell or lived. However, isolated spherical and rod-shaped structures, indistinguishable from those in the filaments, are widely scattered in the matrix and indicate that release of cells by degradation of sheaths or some other mechanism resulted in wide dispersal of individual structures. Clumps of spherical unicells are also present in several separate laminae in $62 \mathrm{ABa} 2541$, as seen in thin sections cut oblique to the bedding. Rod-shaped structures are not present in these masses of coccoid cells, which are here referred to a separate taxon (?Cyanobacteria Coccoid Type A).

A few specimens suggest that this organism had a branching capacity. In most of these cases, rod-shaped units are present at the site of possible branching, but in two specimens (pl. 3, figs. 5, 6) a spherical cell occupies this position. Sheath material has not been observed at points of possible branching. Whether or not branching is present, however, is conjectural because chance preservation of broken, different filaments in positions that mimic branching is possible for these few occurrences.

Greater average diameter of the spherical structures suggests that they are not pieces of a rod that developed a spherical shape before or during mineralogic replacement. The spheres are more likely to be single cells that represent a functional role that is different from that of the rods.

Rods in the filaments were measured to determine whether or not length classifications that might reflect numbers of cells or other internal organization are present; however, no persistent relation of length to width or step increases in length could be documented. This circumstance may reflect change from original shape and size by differential growth of replacement minerals in rods of more equal original size.

The tendency for filaments to be made up of rods having more or less rounded ends, with or without interspersed spheres, in a now very degraded sheath indicates that these arrangements represent original morphology. One fragment of filament (pl. 3, fig. 2) appears to have been uniformly tubular and preserved in the process of breaking into elongate segments the size and shape of the rods in the more typical filaments. No spheres are associated with this short specimen, which may represent a separate taxon that could include co-occurring filaments composed entirely of rod-shaped structures. However, on the basis of available material, and in view of the poor state of preservation, formal recognition of a separate taxon for it is unwarranted.

In some of the filaments the rods, and spheres if present, are preserved in regular linear array. More common- 
ly, however, these elements are slightly disarranged. In filaments containing both rods and spheres, there is a notable tendency for the rods to be more out of line than the spheres are (pl. 4, fig. 3). In several specimens, degraded sheath material and spheres lie in a straight line and rods lie partly outside or are completely gone, leaving spaces in which rods would fit between remaining spheres. Whether or not it can be inferred from this that the rods were motile, and the spheres nonmotile, is conjectural. However, an explanation for the tendency of the rod-shaped elements to escape the filament is called for because there is no evidence of current action or other obvious external control of cell distribution. One possibility is that the rod-shaped elements are hormogones, which in modern nostocaleans are known to be capable of moving out of the parent filament to form a new filament.

This fossil is widely distributed in the volcanic rocks and shale sequence along Washington Creek, as indicated by the number of localities listed below. The most complete preservation of filaments is in $62 \mathrm{ABa} 2541$. In all occurrences except $62 \mathrm{ABa} 2541,63 \mathrm{ACn} 2452$, and $\mathrm{A}-1400$, the organism is represented by very short lengths of filaments (two to four elements) or by isolated rods and spheres. In all samples except $62 \mathrm{ABa} 2541$ and A-1400, the fossils are completely replaced by opaque material, presumably pyrite. Occurrence A-1407, from within the argillite and quartzite unit underlying the volcanic rocks and shale beds, does not necessarily mark the earliest appearance of this fossil in the section because the beds including A-1407 appear to have been folded (or faulted) into the lower sequence (M.W. Payne, written commun., 1978).

Occurrence.-62ABa2541, 63ACn2452, A-1405, A-1392, A-1394, A-1407, A-1406, A-1400, A-1396, A-1397, A-1398, A-1399, basalt and red beds unit(?), Washington Creek, Nation area.

\section{?CYANOBACTERIA}

Filament Type A

Plate 4, figures 9-12

Description.-Trichome multicellular, uniseriate, apparently unbranched, very slightly constricted at septa; terminal structures not observed; crosswalls thin, granular in appearance; cells cylindrical, 4.5 to $5 \mu \mathrm{m}$ wide, 3 to $4.3 \mu \mathrm{m}$ long; special reproductive structures not identified.

Type specimen. $-\mathrm{A}-1395-2$ at $93.9 \times 20.9$.

Discussion.-Two specimens of apparent cyanobacterial filament occur in the matrix of a poriferan-spicule-rich horizon in the volcanic rocks and shale sequence in Washington Creek. One specimen, in two pieces, shows no evidence of sheath material and is preserved as a slightly sinuous structure with a total length of $195 \mu \mathrm{m}$. The cell walls are incompletely represented, and many show distortion associated with the growth of secondary silica inside and outside the trichome. Where better preserved, however, both the crosswalls and outer walls are smooth, and the trichome as a whole exhibits very little variation in width.

A second specimen $210 \mu \mathrm{m}$ long that is located nearby in the matrix is here referred to the same species but could represent an additional taxon. It differs in having a very pale, sheath-like cover 6 to $7 \mu \mathrm{m}$ thick surrounding a central darker area made up of uniserially arranged, replaced cells of similar dimensions and shape as those in the other specimen. An unusual feature of the outer layer of the second specimen is that it has very pale, but distinct, membrane-like structures arranged more or less perpendicular to the long axis of the filament. Although this outer layer could reflect sheets of secondary silica, as seen in bands along the margins of filamentous and other fossils at Takoma Bluff, detailed morphology suggests a biological origin. The membranes, about $0.2 \mu \mathrm{m}$ thick, are preserved as minutely beaded features that commonly bend slightly near the dark central zone and (or) near the outer margin and have the same range of spacing as the cells. Cells in the trichome are not sufficiently well preserved to confirm that the membranes in the sheath(?) always line up with the crosswalls in the trichome, but in a few cases this relation can be seen. The outer margin of the sheath(?) is slightly irregular; where best preserved it appears as a smooth dark line about $0.2 \mu \mathrm{m}$ wide. The surrounding matrix is composed of clear, irregularly sized and shaped silica patches obviously distinct from the sheath(?).

Apparent septation of the sheath, formed by ingrowth opposite the septa of the trichome, is reported in the Family Scytonemataceae by Fritsch (1971, p. 795 and figs. $306 \mathrm{H}$ and $328 \mathrm{H}$ ). One fossil specimen shows this morphologic feature in fine detail, although the trichome is not well preserved; the other specimen has no sheath, but the trichome is better preserved. This evidence could indicate that the two specimens represent different species and, perhaps, different families. However, in the absence of false branching and specialized reproductive structures that might support referral of the sheathed specimen to the Scytonemataceae, and in view of the closely similar size and apparent shape of the cells in both specimens, it seems best for now to simply refer both specimens with question to the Cyanobacteria without assignment to a lower taxonomic level.

Occurrence.-A-1395, basalt and red beds unit(?), Washington Creek, Nation area.

\section{Filament Type B}

Plate 4 , figures 7,8

Description.-Trichome multicellular, uniseriate, apparently unbranched; typically loosely coiled; terminal structures not identified; cells apparently cylindrical, 7.7 
to $9.6 \mu \mathrm{m}$ wide, 7 to $10 \mu \mathrm{m}$ long; special reproductive structures not identified.

Discussion.-This distinctive coiling form is represented by seven specimens, all apparently incomplete. Replacement by a pale-tan mineral has obliterated morphologic detail, although the overall appearance and the width of the specimens are constant. It is extremely difficult to confirm original length of cells because fine corrugation of the outer margin that is not clearly associated with individual replacement crystals hints at a length of 1.5 to $2 \mu \mathrm{m}$, whereas the very faint indications of septa in the central areas of several specimens suggest a much greater length of about 7 to $10 \mu \mathrm{m}$. The internal areas of five specimens appear more or less homogeneous, but two specimens exhibit longitudinal differentiation resulting in a central zone about $2.5 \mu \mathrm{m}$ in diameter. It is possible that these fossils represent sheaths and that the trichome is reflected only in the central zone that appears to be occasionally preserved.

The grouping and degree of coiling in these fossils are reminiscent of Anabaenidium johnsoni, described by Schopf (1968, p. 680) from shallow-water deposits of the Bitter Springs Formation of Australia, which may be a coiled specimen of the co-occurring Cephalophytarion. Cells in $A$. johnsoni, in which a sheath is not reported, average $2.2 \mu \mathrm{m}$ in length and $2.4 \mu \mathrm{m}$ in width. Poor preservation of the Alaskan material, however, does not permit referral of it to the Australian species.

Occurrence.-A-1392, basalt and red beds unit(?), Washington Creek, Nation area.

\section{Filament Type C \\ Plate 2, figure 6}

Description.-Filament $3.8 \mu \mathrm{m}$ wide and $22 \mu \mathrm{m}$ long (incomplete), wall apparently straight; cells subrectangular, about $0.9 \mu \mathrm{m}$ long and $3.7 \mu \mathrm{m}$ wide.

Discussion.-A single, poorly preserved incomplete specimen was observed in Eagle area rocks in association with spherical cells described as ?Cyanobacteria Coccoid Type B and with oval cells described as Protista Incertae Sedis Type C. The filament occurs in a pale chert lamina in highly organic black shale. It is sinuous but of persistent width and has distinctly straight ends that suggest breakage. The preserved structure is interpreted to be a fragmented trichome.

This very poor specimen is described here only to note the presence of a filamentous form in the Eagle area, from which only coccoid cells are otherwise known at present. The filament is consistent in size with prokaryotic cyanophytes but could represent a eukaryotic algal group.

Occurrence.-A-1386, greenstone unit, Eagle area.
Coccoid Type A

Plate 4, figures 5, 6

Description.-Cells spherical, about 8 to $15 \mu \mathrm{m}$ in diameter, surface texture uncertain; cells preserved in masses loosely enclosed in apparently structureless, replaced mucilage.

Discussion.-Masses of dozens to hundreds of replaced coccoid cells occur in several laminae at $62 \mathrm{ABa} 2541$ in Washington Creek. The filamentous form described herein as Paleonostocalia irregularia, which occurs in the same sample, is not present in the laminae containing the coccoid masses. Cells in the masses are replaced by a yellow to amber to dark-brown mineral, presumably limonite, and accompanied by yellow, replaced, apparently amorphous mucilaginous material in which the cells are closely to loosely distributed (pl. 4, fig. 6). Distinct masses are commonly $60 \mu \mathrm{m}$ or more thick and as long as $150 \mu \mathrm{m}$ as seen in thin sections cut oblique to the bedding plane. These masses occur intermittently along the laminae in which this fossil is present, and the intervening areas between dense masses contain smeary patches of degraded mucilage with or without occasional cells. Most of the masses have irregular, obviously fragmented margins, but in several instances a smoothly curved periphery that may represent an original colony margin is preserved.

Cells range in size from 7.6 to $15.2 \mu \mathrm{m}$ in diameter; 53 out of 65 cells measured range from 11 to $13 \mu \mathrm{m}$. Replacement has obliterated the wall to the extent that original thickness and surface texture cannot be confirmed. Many of the cells have slightly darker central areas, commonly one-half to two-thirds of the cell diameter, that occasionally exhibit concentric structure probably related to different phases in growth of replacement minerals.

A few occurrences of intimate association of groups of several cells within a more discrete mucilage envelope were observed, but in the overwhelming majority of cell clusters the cells appear to be more or less independent. Close proximity of two nearly equal-sized cells with apparent common mucilage cover has also been observed. These specimens may reflect preservational phenomena or recently divided cells that have not yet acquired the typical separate position in the mucilage mass. Only two cells less than $9 \mu \mathrm{m}$ in diameter were found among 65 cells measured in random scans. This rarity of small cells suggests that reproductive mode in this organism was by nearly equal fission. A few slightly elongate cells that may represent an early stage in cell division are present, but no cells with buds were observed.

Identification of cells of this organism among the isolated spheres occurring randomly in other laminae at $62 \mathrm{ABa} 2541$ is difficult because spherical cells from the 
co-occurring Paleonostocalia look similar and overlap in size range. In the laminae having masses of Coccoid Type A, however, absence of the rod-shaped structures abundantly present in other laminae, together with the greater average size of coccoid cells in the masses, suggests that the masses represent a different taxon. This interpretation is supported also by the fact that similar cell masses are not present in the many other horizons in the volcanic rocks and shale beds that contain Paleonostocalia except at $63 \mathrm{ACn} 2452$, in which heavily replaced pyritic masses of similar size and containing at least a few discrete spheres may represent Coccoid Type A.

Recognition of an affinity of these cell masses with a modern genus is difficult because colony shape and manner of cell division are not certain. Modern Aphanocapsa forms large colonies with numerous spherical cells loosely embedded in mucilage that exhibits no laminar structure. Modern species referred to Aphanocapsa typically have cells less than $10 \mu \mathrm{m}$ in diameter, smaller than the apparent range of sizes present in the fossil material. However, absence of a recognizable wall in the fossil cells and the very real possibility that size of mineral replacement differs from original cell size preclude confident assumption that the fossil cells were originally the size now measured.

Occurrence of these fossils in a basinal setting presents a problem in terms of comparison with modern analogs not known in similar habitats. Unless the mucilage in the fossil coccoid organism was extremely cohesive, it is difficult to interpret that the cell masses could have retained their present morphology during significant downslope transport. A more reasonable interpretation is that the masses represent floating colonies that have settled on the bottom in the very low-energy environment consistent with the minutely laminated character of these sediments.

Occurrence. $-62 \mathrm{ABa} 2541$ and $63 \mathrm{ACn} 2452$, basalt and red beds unit(?), Washington Creek, Nation area.

\section{Coccoid Type B}

Plate 2, figure 3

Description.-Cells spherical, 3.8 to $11.5 \mu \mathrm{m}$ in diameter, single or associated in groups of a few to many individuals; wall apparently thin, very finely granular, surface smooth; internal area clear or has dark, round central spot.

Discussion.-These spherical structures are preserved in several different manners in a laminated dark shale in the Eagle area. Rare, finely granular brown spheres occur in pale chert laminae. Clear siliceous envelopes are present around some of these, particularly near the interface between dark and pale laminae. Others have no silica rims, and the cell wall is typically medium brown and has no evident surface sculpture. Less-well-preserved spheres are partly to completely replaced and appear as clear silica surrounded by very dark brown, presumably degraded, organic material. This mode of preservation is especially common in packed masses of cells in the darker laminae.

Spherical cells in this shale fall within the size range of unicells of the Takoma Bluff, Nation, and Eagle fossils referred to Sphaerocongregus or Bavlinella but differ from them in having less-hyaline walls and a more restricted size range. The spherical multiunits, uniseriate chains, and dividing or budding cells present in the Sphaerocongregus biotas have not been observed in this Eagle material. Although a cyanobacterial affinity seems likely for them, they could represent a morphotype of a form found with them and described as Protista Incertae Sedis Type $\mathrm{C}$ that also produced spherical cells.

One clump of about six smaller $( \pm 2.5 \mu \mathrm{m})$, smoothwalled coccoid cells was observed in one of the paler laminae. Although extremely difficult to see, cells in the clump differ from others in this material not only in being smaller but also in having an apparently thicker wall and in being tightly packed into subspherical shapes. No mucilaginous or membranous envelope encloses this small mass, which may represent recently divided cells of an additional coccoid species.

Occurrence.-A-1386, greenstone unit, Eagle area.

\section{ACRITARCHA}

\section{ACANTHOMORPHITAE}

Downie, Evitt, and Sarjeant, 1963

\section{Acanthomorph Type A}

Plate 17 , figures $1-3,5$

Description.-Vesicle 24 to $62 \mu \mathrm{m}$ in diameter; processes typically numerous, hollow(?), as long as $24 \mu \mathrm{m}$ and 1 to $1.5 \mu \mathrm{m}$ in diameter, branching in some specimens.

Discussion.-Seven specimens of acanthomorph acritarchs, observed in a small sample from the Woodchopper area, are poorly preserved as spiny black structures, in some cases apparently crushed and distorted. One specimen with very short processes is clearly distinct and is described below as Acanthomorph Type B. The remaining six have numerous, sinuous processes. A few processes exhibit open triangular structure near the base suggesting that they were hollow, but most are opaque throughout their length. In three of the six specimens, a few processes exhibit evidence of branching, which is typically a bifurcation about two-thirds of the distance from the base. One process in this specimen also exhibits very fine terminal 
branches, and several processes in a different individual appear to have occasional, more irregular branching between the middle and the end of the process. The vesicle wall is generally so difficult to see that original morphology is uncertain. One specimen appears to have had a smooth wall with processes arising abruptly from the surface, but in the others there is some evidence that the process bases flared, causing the wall to have a deeply sculptured appearance. Although it is entirely possible that more than one taxon is represented among these six specimens, preservation is so poor and the possible effects of distortion so difficult to assess that recognition of several taxa is not justified at present.

Acanthomorphs of generally similar types are reported in Lower Cambrian rocks of eastern Europe (Timoféev and others, 1976, tables XXVII-XXVIII; Volkova in Raaben, 1981, p. 259-273, tables XLVI-LI). More highly varied forms appear by Middle Cambrian time (Timoféev and others, 1976), and Middle Ordovician forms showing additional morphologies are reported from the USSR by these authors and from Oklahoma by Loeblich and Tappan (1978). The nature of the processes (hollow or solid, equally or inequally branched, and so forth) are important characteristics in recognition of genera within the group. Inasmuch as these features cannot be confirmed for the Alaskan material thus far available, it seems best not to refer them to previously described genera or to apply a new formal name.

Occurrence.-62ABa2132, undivided sedimentary rocks unit, Woodchopper area.

\section{Acanthomorph Type B}

Plate 17, figure 4

Description.-Vesicle oval, $45 \mu \mathrm{m}$ long and $30 \mu \mathrm{m}$ wide; outer wall apparently smooth, thin; processes unbranched, sparsely distributed, apparently solid, as long as $3 \mu \mathrm{m}$ and about $0.7 \mu \mathrm{m}$ wide.

Discussion.-A single acanthomorph acritarch specimen is sufficiently different from the co-occurring forms to warrant its separate recognition. Although the processes in this specimen may not be complete, they are clearly less numerous, shorter, and thinner than those of Type A. They arise abruptly from the nonsculptured vesicle surface and can be seen as dark lines that, in some cases, extend very slightly below the inner surface of the vesicle wall, thus suggesting an originally solid nature. The processes are straight or slightly curved and appear to have been stiffer than the obviously flexible processes of Type A.

Much larger (200 to $500 \mu \mathrm{m}$ in diameter) acanthomorphs with similarly short, straight processes are reported in the Siberian Riphean-age Lokhandinskaya Suite (Timoféev and others, 1976, p. 47-48 and tables XIX, XX), and possible comparable forms that are also larger are reported from Middle Ordovician rocks in Siberia by these authors (1976, table LXV, fig. 7) and in Oklahoma by Loeblich and Tappan (1978, p. 1268 and pl. 11, figs. 1-3).

Occurrence.-62ABa2132, undivided sedimentary rocks unit, southeastern Woodchopper area.

\section{PROTISTA INCERTAE SEDIS \\ Protista Incertae Sedis Type A \\ Plate 17 , figures $6-8$}

Description.-Cells single, spherical to subspherical, to $45 \mu \mathrm{m}$ greatest diameter; wall thin, hyaline, typically wrinkled, surface smooth; no internal structure observed.

Discussion.-Poorly preserved, pale-brown bodies are moderately abundant in medium-gray cherty dolomite from the Woodchopper area. These are described from a small sample from an outcrop between Takoma Bluff and Edwards Creek (62ABa2132) and from an isolated outcrop $60 \mathrm{~km}$ to the northeast (BC 75-62) assigned to the same map unit by Brabb and Churkin (1969). The empty hyaline bodies are rounded to oval and range in size from $9 \times 10 \mu \mathrm{m}$ to $21 \times 45 \mu \mathrm{m}$ with no dominant size within this range. Most specimens appear to have had extremely thin walls that now have irregular, small to large holes that give the preserved wall a lacy appearance. In some individuals, the outer surface looks bubbly, but this does not appear to reflect original multicellular structure. Occasional specimens are distinctly longer than wide and have moderately sharp ends. These typically have one or more long folds in the wall that differ somewhat in appearance from the more irregular wrinkling seen on most specimens. Occasional loosely clustered, more granular appearing bodies (pl. 17, fig. 8) are also present; these are distinctive and may well represent a separate taxon.

Microfossils of this type, interpreted as phytoplankton and commonly referred to the Acritarcha, have been assigned to many genera and species described from rocks of Proterozoic age (Vidal, 1981; Hofmann, 1984) and of Tommotian age (Raaben, 1981, table XLVI-XLIX). However, preservation of the Alaskan material is very poor, and, in view of the restricted amount of sample material available, it is unlikely that a full representation of the contemporary microbiota has been seen.

Occurrence. $-62 \mathrm{ABa} 2132$, undivided sedimentary rocks unit, Woodchopper area.

\section{Protista Incertae Sedis Type B Plate 17, figure 9}

Description.-Vesicle $24 \mu \mathrm{m}$ in diameter; wall thin, smooth, nearly hyaline; single hollow process $14 \mu \mathrm{m}$ long, 
diameter tapering from $4.7 \mu \mathrm{m}$ at base to $2.3 \mu \mathrm{m}$ near end, flaring slightly at open(?) tip.

Discussion.-A single specimen of this distinctive form was observed. It occurs with acanthomorph acritarchs and with Protista Incertae Sedis Type A, from which it differs in having a smooth (rather than wrinkled) outer wall and in having a hollow extension. Some of the similar-sized fossils referred here to Type A may be Type B, but poor preservation does not permit confirmation except for this individual. As is typical in this fossil biota, the pale brown wall is degraded and apparently very thin. The hollow process appears to flare very slightly near the preserved distal end.

Generally similar fossils described as Deunffia dentifera Volkova (in Raaben, 1981, p. 270, table L, figs. 29-31) have oval vesicles 11 to $17 \mu \mathrm{m}$ long with processes about 13 to $17 \mu \mathrm{m}$ long. They occur in the Lower Cambrian of northwest Poland and were referred by Volkova to the Netromorphitae in the Acritarcha as classified by Downie and others (1963). Unnamed Form A of Knoll (1982) from the Late Proterozoic of Svalbard is of similar or larger size than the Alaska specimen.

Occurrence. $-62 \mathrm{ABa} 2132$, undivided sedimentary rocks unit, southeastern Woodchopper area.

\section{Protista Incertae Sedis Type C}

Plate 2, figures 1,2

Description.-Cells oval, typically with rounded ends, from 7.7 by $22 \mu \mathrm{m}$ to 13 by $35 \mu \mathrm{m}$ in size; wall apparently less than $1 \mu \mathrm{m}$ thick, no visible laminae or pores, external surface smooth; internal area typically featureless.

Discussion.-These markedly smooth-walled cells occur as medium- to dark-brown ovals in thin chert laminae in a richly organic black shale in the Eagle area. The ovals, and some of the co-occurring spherical bodies described as ?Cyanobacteria Coccoid Type B, may have secondary silica envelopes around part or all of the periphery. The darker laminae in this shale are so densely packed with degraded organic material that they are essentially opaque, so it is not known whether the ovals are present also in these layers.

In addition to the complete ovals measured, numerous incomplete specimens were observed. These tend to be broken across the long axis and indicate that the cell wall is less than $1 \mu \mathrm{m}$ thick. Occasional otherwise typical specimens exhibit faint evidence of an axial zonation, which may be a preservational phenomenon. Although most individuals have evenly rounded ends, one (pl. 2, fig. 1) is markedly tapered to a sharp, slightly curved point at one end and broadly rounded at the other; this morphology invites the speculation that polarity and motility may have characterized this organism at some stage of its life cycle.
These oval fossils are generally similar to Oval Spore Type A from Takoma Bluff, interpreted to be fungal, but differ in having thinner walls and more highly varied size and shape. Hyaline oval bodies from east of Takoma Bluff, described as Protista Incertae Sedis Type A, are smaller and typically have wrinkled rather than smooth surfaces. Phyletic affinity of the Eagle ovals is highly conjectural inasmuch as they are essentially featureless. The appearance of the wall is not markedly different from that of the accompanying spherical cells, described as ?Cyanobacteria Coccoid Type B, which range in diameter from 3.8 to $11.5 \mu \mathrm{m}$. The latter occur singly or in groups of several to many individuals, but, in all cases seen, the ovals are clearly well separated from one another and from the spheres, suggesting an independent habit if not an independent origin. Smooth oval cells of types generally similar to the Eagle fossils are common in many algal groups, including flagellate forms in the Volvocales.

Occurrence.-A-1386, greenstone unit, Eagle area.

\section{Protista Incertae Sedis Type D \\ Plate 16, figure 8}

Description.-Unicellular, about 14 to $30 \mu \mathrm{m}$ in diameter; wall hyaline, $2 \mu \mathrm{m}$ thick, apparently nonlaminar and porous, surface fairly smooth; wall has internal border of finely granular material containing radially arranged canals(?) passing from inner dark peripheral area through outer wall; central area has partial(?) curved membrane about $2 \mu \mathrm{m}$ thick.

Discussion.-This unusual fossil is represented by one large (30 $\mu \mathrm{m}$ diameter) well-preserved specimen and two, apparently similar, smaller individuals. Description is based primarily on the large specimen, which is silicified; smaller specimens have been replaced by clear, orange, probably iron minerals. The colorless outer wall is defined externally by an extremely thin dark film and internally by a smudgy, wider dark zone. The latter may represent a membrane, but its margins are not sharp and it is preserved as a concentration of very fine granular material. The next internal zone is of irregular thickness, as preserved, and is composed of a smooth, mediumbrown, granular(?) material traversed at intervals by radially arranged, pale, thin lines that appear to be open channels without observable membrane linings. Several of these can be traced through the outer wall where one was seen to terminate in a very slight convexity of the outermost surface of the cell. These canals(?), although not completely regularly arranged, tend to be well separated. A total of seven can be seen in one focal plane when examined at high magnification $(\times 1250)$ under oil immersion. Thinner, less persistent, pale radial lines are present in the inner peripheral material between the more pronounced canals(?). These lines do not penetrate the 
dark membrane(?) at the base of the hyaline outer wall and could, inasmuch as they are otherwise similar, indicate that all of the radial pale structures are secondary phenomena rather than original morphologic features.

The partial circle of hyaline material inside the cell exhibits no radial features. The fact that the ends of this C-shaped structure are not covered with granular material, as are its inner and outer surfaces, suggests that the structure is incomplete. Granular material around the outer rim of the central structure (lower left area of the inner part of the cell in pl. 16, fig. 8) is nearly continuous with the inner peripheral zone, suggesting that perhaps all of the cell except the outer wall and central spherical(?) structure was originally filled with the material here described as the inner peripheral zone.

The phyletic affinity of this fossil is difficult to assess because it is not certain if the central C-shaped structure represents an originally complete sphere. Because this structure is clearly centrally located and is related to surrounding internal cell contents, and because the outer wall shows no evidence of breakage, the C-shaped structure must be interpreted to represent an original intracellular feature of some sort. Except for the absence of canals(?), the hyaline material composing the C-shaped structure is of the same thickness and appearance as the outer wall. Most of the very abundant cells in shales at this locality are silicified and show no radial preservational features, and the replaced cells in the particular horizon containing Type $\mathrm{D}$ are now made up of minute crystals of hyaline iron(?) minerals that exhibit no radial arrangement and represent mostly Sphaerocongregus variabilis. This circumstance and the consistent and very delicate nature of the pale radial canals(?) support interpretation that the latter reflect original morphology.

The only possibly comparable fossil seen thus far in the Alaska material is Protista Incertae Sedis Type F (pl. 16, figs. 5, 6), which occurs also with Sphaerocongregus variabilis in a neighboring shale horizon at A-1409. Type F, however, has thinner, siliceous, apparently nonporous outer walls that have no dark basal layer; it also has more coarsely granular intracellular material, no radial structure, and no central capsule. As discussed below, absence of phyllosilicate bands on Type $F$ and presence of them on co-occurring comparable-sized plant cells and cell clusters may suggest that Type $F$ is an animal-like rather than a plant-like protistan. Type D has silicate bands and a thick organic wall, as do the fossils described herein as fungal spores. If the secondary silicate growth phenomena associated with known plant cells in the Woodchopper and Eagle biotas do relate to the original composition of the organism, a plant origin would be suggested for Type $\mathrm{D}$. However, the distinctive radial structure and porous wall of Type D, together with its possible thick-walled central capsule invites at least gross morphologic comparison with the Radiolaria.
Occurrence.-A-1409, undivided sedimentary rocks unit, Takoma Bluff, Woodchopper area.

\section{Protista Incertae Sedis Type E \\ Plate 12, figures 8,9}

Description.-Multicelled, colonial(?) structure of 250 $\mu \mathrm{m}$ greatest diameter, composed of about 18 similar multiunit spheres 19 to $33 \mu \mathrm{m}$ in diameter; subunits tightly packed, about $2.8 \mu \mathrm{m}$ in diameter; multiunits arranged in crescentic uniseriate row with partial second (and possible third) row of similar spheres arranged along inner ends of complete crescent; margin of whole structure distinct but without apparent membrane around periphery or between rows.

Discussion.-A single specimen of this unusual fossil was found at A-1408. The secondary phyllosilicate bands adjacent to other large plant fossils in this shale are also present on two sides of Type E, usually without apparent distortion of cell shape. Most of the multiunits are nearly spherical, but several are poorly preserved and do not now contain subunits. These latter have a finely granular margin typically convexly scalloped at a scale consistent with that of intact multiunits. The complete crescentic row (top of fig. 8 of pl. 12) is composed of four multiunits on one side, five on the other side, and a degraded structure between them that may have included more than one cell (fig. 11). Although poorly preserved, this structure may have been different from the multiunits in the remainder of the row.

The second crescentic row includes two short lengths of multiunits that are slightly different from those in the first row. On the left, the middle member of the three preserved structures is slightly out of line, has no lower silicate band, and looks like a deformed multiunit. This position on the right side is occupied by one empty multiunit(?) and a closely adjacent multiunit, both of which are $14 \mu \mathrm{m}$ in diameter, considerably smaller than other multiunits in this fossil.

The area between the inner ends of the second, incomplete(?), crescentic row contains typical matrix material of silica and irregularly scattered pieces of degraded organic matter; it also contains four poorly preserved apparent unicells arranged in a single series. These four cells are aligned along the arc formed by the multicells on the right side of the second row. Cells in this middle area of the row are distinctly smaller and smoother walled than the multiunits at each end, with which they appear to be continuous. The series of smaller cells ends abruptly on the left at a cluster of polyhedral crystals of an opaque mineral, possibly pyrite.

A possible third crescentic row is represented by two multiunits lying to the left of the inner end of the right side of the second row. Although poorly preserved, these two structures definitely are similar to the other large 
multiunits in the fossil, and they lie in a position consistent with the concentric geometry of the structure as a whole.

Adjacent multiunits are typically in contact, but their touching margins are not flattened and no tubular or other structures appear to connect them. The curved area between the first and second row contains typical matrix material, including randomly distributed multiunits of the co-occurring Sphaerocongregus and a thick-walled oval cell similar to those described herein as dispersed fungal spores of uncertain affinity. No persistent membrane was observed in the area between these rows or around the periphery where the outer margins of multiunits either have phyllosilicate bands or are in direct contact with the matrix.

The sizes of cells in this fossil are consistent with either a plant or an animal origin. However, the arrangement of cells in series and the nature of subdivision of the multiunits indicate that a plant origin is more likely. Whether or not this fossil should be considered as colonial is questionable. The highly consistent external morphology of the multiunits, their regular arrangement, and the absence of dividing cells provide no good evidence of the mode of reproduction or growth of the organism, although the subdivided spheres may contain spores potentially capable of initiating a new colony(?).

What are interpreted here as uniseriate crescentic rows of multiunits and unicells may be a fortuitous orientation

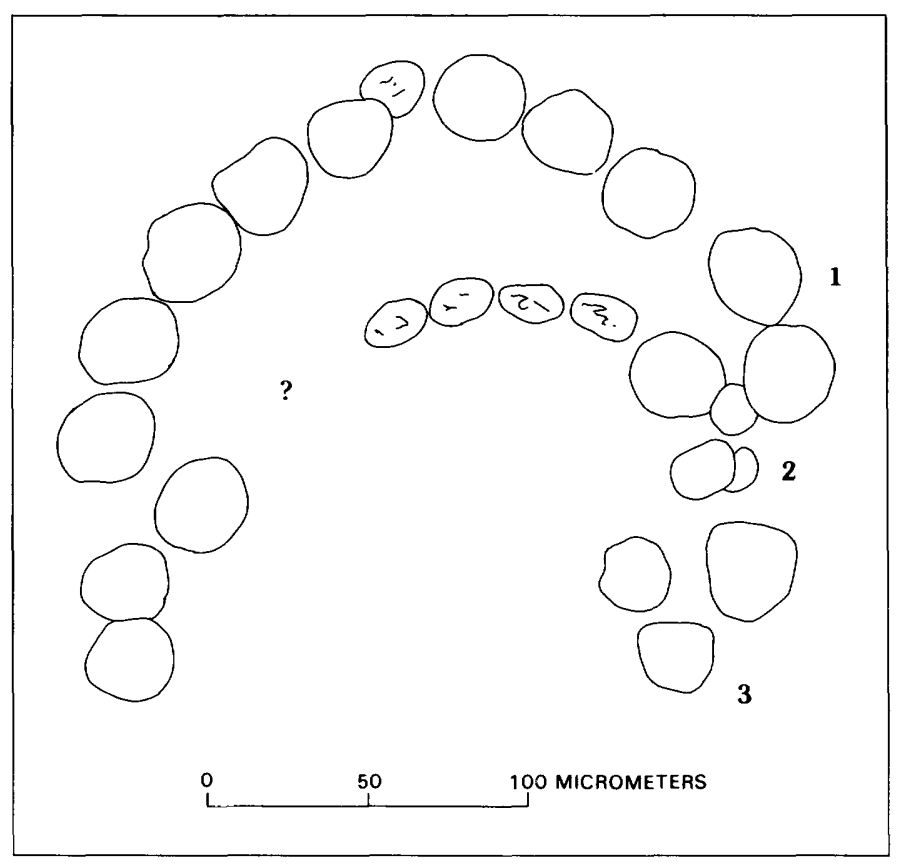

Figure 11.-Structure of Protista Incertae Sedis Type E. Numbers 1, 2 , and 3 refer to crescentic rows discussed in description of this fossil. Except for four small cells toward center of second row, and apparent small cell near center of first row, all spheres are multiunits as shown on plate 12 , figure 9 . in this thin section of an organism of more complex original three-dimensional geometry. However, the striking symmetry and alignment of cells in one plane suggests that if the organism was originally more complex in this sense, additional cells must have lain above or below those in the plane of the thin section. Similar-sized multiunits have not been seen elsewhere in the biota, thus it is difficult to confirm that this fossil is in any way incomplete. Because these cells are so much larger than others seen in the biota, they are unlikely to represent different growth stages of the accompanying cyanobacteria or fungi.

Whether or not this fossil represents a known algal or fungal group is not certain. No described species of comparable structure or symmetry has been located by the author.

Occurrence.-A-1408, undivided sedimentary rocks unit, Takoma Bluff, Woodchopper area.

\section{Protista Incertae Sedis Type F}

Plate 16, figures 5, 6

Description.-Unicellular spherical bodies about 19 to $27 \mu \mathrm{m}$ in diameter; outer layer siliceous, approximately $1 \mu \mathrm{m}$ thick; internal area finely granular, with or without irregularly shaped nongranular patches.

Discussion.-Thirty-six specimens of this silica-rimmed spherical structure were observed in random distribution in the matrix of A-1409. These range in diameter from 18.3 to $27.3 \mu \mathrm{m} ; 80$ percent of the individuals fall within the range of 19 to $24 \mu \mathrm{m}$. The outer layer varies little from $1 \mu \mathrm{m}$ in thickness and appears to have a smooth external surface. Examination under high magnification in polarized light reveals the outer wall as a homogeneous, somewhat milky layer in which no individual crystals can be distinguished and no evidence of concentric laminar structure is apparent. However, this layer is so thin and difficult to analyze that the original microstructure cannot be confirmed. As described in discussion of the cooccurring Sphaerocongregus variabilis, secondary silica in this shale is common as thin sheets in bands along opposite sides of large plant cells and cell masses but is not present as an all-enveloping layer. Therefore, if the silica rim on these spheres is secondary, the phenomenon is unique to Type $\mathrm{F}$.

Under high magnification, the margin between the inner brown granular area and the pale rim appears much less regular than the outer surface of the rim and shows no evidence that a membranous separation was present. In fact, occasional granules of the dark inner material very near the outer surface of the silica rim suggest an intimate admixture of organic contents and silica, although the distribution of dark granules in the peripheral layer does not suggest pores through the rim. The fine, evenly distributed nature and the distinctive reddish-brown 
coloration and granulation of the central area in these spheres are also unique in the biota at A-1409 in which plant cell walls are light to dark brown and finely granular or, occasionally, hyaline and slightly greenish in color.

Granules are typically less than $0.5 \mu \mathrm{m}$ in size and irregular in shape. They may be evenly distributed or occasionally clumped together in very short threads or small patches. None of these suggests a nucleus or other discrete intracellular body. Occasional spheres contain nongranular, highly irregularly shaped areas, commonly about $6 \mu \mathrm{m}$ in diameter, that are not visibly membrane bound. They tend to be centrally located and have pointed lobes extending toward, and in several individuals reaching, the marginal silica layer.

Biologic affinity for these rather featureless spheres is difficult to conjecture. Their narrow size range and consistent, unusual appearance argue against a nonbiologic origin, and the basinal depositional setting of the enclosing shale discourages identification of them as oolites or pisolites. They are clearly different from accompanying plant cells in both color and presence of a granular interior and in possessing a complete silica envelope. The only comparably preserved fossils seen, at A-1392 in Washington Creek, are the consistently larger Brabbinthes and associated stellate and rounded structures in which the central granular areas and silica envelopes are strikingly similar to Type F. Although the phyletic affinity of these Washington Creek fossils remains in some doubt, a plant origin for them is questioned because their morphology, color, and preservation clearly differ from co-occurring undoubted plant cells. Many spherical forms are known among protistans, including the gromiid foraminifers and other animal-like groups. However, I have not identified a comparable silica-enveloped form among them, and it appears best for the present to simply refer these unusual fossils to the Protista.

Occurrence.-A-1409, undivided sedimentary rocks unit, Takoma Bluff, Woodchopper area.

\section{Protista Incertae Sedis Type G}

Plate 11, figures 2, 3

Description.-Spherical, apparently colonial organism composed of an outer, single layer of closely spaced spherical bodies, presumably cells, surrounding a noncellular internal area; nature of colony wall, detailed structure of spherical bodies, and presence or absence of other original structures not known. Colonies 54 to $84 \mu \mathrm{m}$ in diameter; cells in outer layer 11 to $15 \mu \mathrm{m}$ in diameter.

Discussion.-These curious structures are relatively common at A-1392 where they occur with metazoan fossils. They are preserved as round patches of silica with convexly scalloped margins that are very consistent in shape. Examination under polarized light confirms that the silica represents secondary replacement without preservation of discernible organic cell walls. Range in size of the colonies, as seen in thin section, probably at least in part reflects variation from an equatorial section because individual cells are essentially the same size in all specimens, but specimens having larger diameter exhibit more cells around the margin. In ordinary transmitted light, most individuals show no evidence of colony structure beyond that indicated by the outer scalloped margin; however, examination in polarized light confirms that individual spheres are closely spaced, although not appressed, and that the organism was not composed of a solid ball of cells. Opaque patches in the central areas of some specimens may represent degraded organic material or a secondary, nonbiogenic deposit. Fine films of dark granular material are present on the surface of spicules and several other fossils otherwise preserved as clear silica in several other shales in these beds, but there are no such dark rims or other evidence of walls or mucilage around Type G colonies. All colonies seen are spherical rather than oval or otherwise distorted and broken, suggesting that, regardless of whatever bound the outer layer together, the spheres were not easily subject to degradation, distortion, or breakage.

The shape, size, and apparent organization of these fossils suggest that they may represent colonial, probably planktonic and possibly flagellate organisms. Cell sizes are consistent with either a plant or animal origin. Generally similar organization is known in the flagellate Volvocales, but cells in modern colonies in this group are typically loosely spaced within or around the margin of a mucilaginous mass and contain fewer individuals than are apparently present in these fossils. Although no identifiable plant material is present in this particular shale, plant fossils are abundant in many similar shales in these beds; however, the plant fossils are typically replaced by iron minerals and never by clear silica. Referral here of these almost certainly biogenic structures to the flagellate Protista must be regarded as conjectural. It is based solely on the fact that modern ciliates do not include types organized into similar colonies of spherical bodies whereas such forms do occur in the flagellates. However, there is no compelling reason to assume that these fossils had any locomotor structures. They could represent passively floating colonies or, in fact, a multicelled reproductive stage of a plant or animal not otherwise identified in the Washington Creek biotas.

Occurrence.-A-1392, basalt and red beds unit(?), Washington Creek, Nation area.

\section{FUNGI PHYCOMYCETAE ?Order SAPROLEGNIALES}

\section{Genus CYLINDROMYCES n. gen.}

Type species.-Cylindromyces septatus $\mathrm{n}$. sp.

Description.-Filaments cylindrical, 30 to $40 \mu \mathrm{m}$ in diameter, as long as $600 \mu \mathrm{m}$, commonly curving, rarely 
branching, with complete(?) septa; terminal(?) segment slightly tapered; outer wall apparently smooth and singlelayered; filaments may contain numerous, typically spherical cells.

Cylindromyces septatus $\mathbf{n}$. sp.

Plate 12, figures 1-7

Description.-Filaments slightly to distinctly curved, typically of constant diameter except for slight tapering toward terminal(?) portion in some specimens; outer wall about $2 \mu \mathrm{m}$ thick, straight or with faint constriction at junction with septa; septa approximately $1.5 \mu \mathrm{m}$ thick, apparently complete or having pore(s), dividing filament into segments typically 45 to $60 \mu \mathrm{m}$ long with terminal(?) segment as long as $100 \mu \mathrm{m}$; filaments empty or with one or more segments containing closely spaced, thin-walled spherical cells of about 4 to $10 \mu \mathrm{m}$ diameter; manner of branching not well known, apparently dichotomous and without notable development of septum at base of branch.

Type material.-Thin-section A-1408-3 (one of three containing this fossil).

Discussion.-These poorly preserved fossils are common at A-1408, where they occur as dark-brown tubular structures with or without included cells and septa. As with other larger plant fossils in this shale (and at A-1409), silicate bands are commonly present along two opposite outer walls of the tubes. The presence of these bands, together with the tendency for the filaments to be broken and to be preserved in the same manner as other undoubtedly indigenous fossils at A-1408, discourages the interpretation that these structures represent postdepositional boring organisms.

Most of the 28 specimens that are at least $70 \mu \mathrm{m}$ long do not contain cells or other evidence of internal structure. In some cases the empty filaments are now filled with mounting medium, indicating that thin-section preparation has differentially removed the original biogenic contents without removing the adjoining silicate bands. Thus it is not certain what percentage of nowempty filaments originally contained septa and (or) cells and whether these were originally typically present throughout the length of the filaments. Several specimens have slightly tapered, apparently terminal parts with basal septa and included cells (pl. 12, fig. 2), whereas others do not taper (pl. 12, fig. 5); the remaining specimens are clearly parts of broken filaments with parallel outer walls and no original terminal portion.

A slight to strong tendency toward a $\mathrm{C}$-shape curve without twisting is typical, although a few apparently twisted filaments were observed. These latter suggest that the outer wall was not very rigid or that these specimens are not twisted but represent variations in degree of constriction of the wall. Both outer walls and septa are preserved as densely granular, smudgy darkbrown lines. Evidence for more than one layer was not seen, although preservation is too poor to be sure. The septa are generally perpendicular to the axis of the filament, but occasional specimens suggest slight curvature near the outer wall. Septa tend to have short, irregularly spaced breaks that are difficult to interpret because even the outer walls commonly display irregular breaks that are not likely to be original. Communication between adjoining segments of septate fungal mycelia in modern species may be through pore(s) or by development of incomplete septa (Fitzpatrick, 1930, p. 134). Either of these morphologies could have been present in the fossil organism.

Sixty-one specimens that clearly represent this organism were closely examined. Of these, 38 are now empty or show no evidence of septation or terminal structures and contain no cells; 13 specimens, with no evidence of terminal structures, contain no cells but appear to have had septa, and 10 have both septa and cells. Of those 10 , at least 6 appear to have terminal segments preserved. Small breaks in the outer walls are so common as to preclude confident identification of terminal or lateral pores in apparently terminal segments.

All cells within the filaments have thin walls, apparently without sculpture or notable granularity. They tend to be closely spaced but are not tightly packed. There is no obvious arrangement of cells within the segments on the basis of size, and there is no dominant cell size within the range of 4 to $10 \mu \mathrm{m}$ in diameter. No cells in the process of equal or inequal fission, or clearly in process of budding, were observed in the filaments, and no spots or other evidence of internal cell structure were seen.

Randomly distributed single cells and sizable, typically somewhat elongate masses of similar cells are present in the matrix at A-1408. These may, at least in part, have originated in the tubular fossils, but an unknown percentage of them may have been contributed by the co-occurring Sphaerocongregus. In a few cases, cells entirely comparable to those inside filaments are distributed adjacent to them in such a manner as to suggest that they were released immediately prior to burial.

The fossil filaments do not lie on a single bedding plane as would be expected if they were planktonic organisms passively fallen to the sea floor. Instead, they tend to pass through the sediment, lying now as though they had lived on, or even partly in, an organic-rich, soft, upper sediment layer. There is essentially no evidence of significant compaction of this sediment before silicification because, although commonly broken, the filaments are not oval in cross section. The twisted appearance of some specimens may reflect the rolling of nonturgid, empty(?) pieces of filament along the surface in response to very gentle bottom currents, although wavy lamination was not observed in the enclosing shale. On the other hand, a planktonic habit cannot be ruled out because solidification and (or) accumulation of an organic-rich, ooze-like, soft sediment could easily have preserved lengths of these 
relatively large filaments that curve in and out of a layer as thin as that seen in thin section.

A number of morphologic features exhibited by these fossils suggest affinity with the phycomycetous fungi and, within this group, with modern organisms placed in or near the Order Saprolegniales. The nature and placement on the mycelium of reproductive structures and the number and type of cilia in the swarmspores, which are definitive in the characterization of various genera within these types of fungi, are not apparent in the fossil material, thus close comparison with a modern genus or species is of dubious value. However, morphologic features that are preserved, including absence of notable constriction of the outer wall and presence of septa, suggest closest similarity to the modern Allomyces, placed by some workers in the Saprolegniales and by others in the Blastocladiales (Fitzpatrick, 1930, p. 130). Allomyces is dominantly aquatic, commonly as a saprophyte on submerged plant or animal debris. Differentiation into a rhyzoid system and branching erect structure, as is common in modern Saprolegniales and Blastocladiales, is not evident in the fossil material; preserved filaments vary little in appearance, and branching, when present, does not result in a decrease in diameter of the filament or in formation of a morphologically distinct terminal sporangium as occurs in Blastocladia, Allomyces, and allied modern genera. Whether the fossil organism was saprophytic is not certain, but the matrix in which this fossil occurs is unusually rich in amorphous and fragmental dark-brown organic matter, presumably representing degraded plant and (or) animal debris.

Alternatives to a fungal affinity for Cylindromyces septatus, at least in terms of currently known modern and fossil organisms, are not persuasive. The large size, together with lack of evidence of cell pairs or cells in process of fission that are clearly associated with Cylindromyces, argues against a cyanobacterial or algal affinity. Absence of such cell associations is clearly more consistent with the spore-forming process in phycomycetes, in which multineculeate, elongate terminal sporangial portions of mycelia develop a thin, membranous internal network that subdivides the protoplasm and forms first polygonal, later spherical, uninuclear spores. This mode of spore formation would account for the nature and size range of the cells in the filaments at A-1408. In modern forms the spores may germinate within the sporangium by forming germ tubes that penetrate the sporangial wall, a process not observed in the fossil material, or they may escape through pores in, or disintegration of, the sporangial wall. Either of the latter processes could have occurred in the fossil organism.

Thick-walled, probably very resistant oval structures that also appear to be fungal occur in the matrix at
A-1408. Description and discussion of possible biologic relationships between these and Cylindromyces are presented below.

Occurrence.-A-1408, undivided sedimentary rocks unit, Takoma Bluff, Woodchopper area.

\section{?FUNGI IMPERFECTI \\ Order FUNGI SPORAE DISPERSAE Elsik, 1976 \\ Family MONOCELLAE Elsik, 1976}

\section{Oval Spore Type A}

Plate 13 , figures $1-3,7,8$; plate 14 , figures $3,5,6$

Description.-Unicellular, typically oval, evenly curved to moderately acute at ends, 11 by $30 \mu \mathrm{m}$ to 23 by $40 \mu \mathrm{m}$ (26 specimens measured); spore wall $2 \mu \mathrm{m}$ or more thick, without visible laminae or pores; surface smooth; betterpreserved specimens hyaline with featureless central area and darker peripheral zone 5 to $7 \mu \mathrm{m}$ wide.

Discussion.-These distinctive structures are commonly preserved as featureless, dense, dark-brown oval bodies randomly dispersed in the matrix. They tend to be banded by phyllosilicates in the manner described above for Sphaerocongregus variabilis. Most of the better-preserved specimens have a dark peripheral zone of nearly even thickness. In two specimens this zone is thinner at some places that do not coincide with the ends of the ovals and that appear to be random. The dark zone is clearly not a secondary external coating and is interpreted as the spore wall.

The external surface appears very smooth in most specimens as seen in transmitted light (pl. 13, figs. 1-3) but reveals a more variable texture under scanning electron microscopy (SEM) (pl. 14, figs. 3, 5, 6). Whether the faintly pitted and laminar texture revealed in this mode reflects an original range of surface textures is uncertain. However, presence of a distinctly rugose surface in some specimens suggests that more than one type of oval spore may be represented in this material. The rugose forms are described below as Oval Spore Type B. Careful search for pores in the walls of Oval Spore Type A specimens yielded equivocal results. In thin section, the betterpreserved hyaline specimens show no evidence of natural openings through the dark zone anywhere around the periphery, and this zone shows no tendency to thin at or toward the ends of the ovals. Specimens in preparations for SEM all lie on their sides, like eggs, making close inspection of the ends of the spores impossible.

The phyletic affinity of these fossils is conjectural. The shape and the thick, obviously resistant walls are unique in the biota at A-1408, and similar cells have not been seen in the other Alaska fossil biotas. Occasional thinwalled, slightly oval cells in the matrix at A-1408 and at 
A-1409 at Takoma Bluff are invariably smaller and have less-defined ovate shapes. These are clearly different and probably cyanobacterial or algal. The fact that the thickwalled oval cells occur with Cylindromyces, interpreted to be fungal, together with the similarity between the oval cells and various types of fungal spores, raises the possibility that two growth phases of a single species are represented. The most promising modern candidate that I located for such an organism is the genus Allomyces, with which Cylindromyces has been compared above. This genus develops nearly spherical thin-walled spores in the elongate terminal sporangia, peculiar resting cells with thick walls, and oval shapes in some species. Sizes of such cells reported in literature I have seen range up to $26 \mu \mathrm{m}$ by $35 \mu \mathrm{m}$ (Coker, 1923, pl. 61, fig. 12), which includes the size range present in this fossil material. The resting cells in modern species are formed in membranous sacs attached to the mycelium, a growth pattern not seen in the fossil material in which the thick-walled cells are invariably well separated in the matrix from Cylindromyces. The Cylindromyces also show no evidence of points of attachment for sacs. Resting cells in Allomyces and the closely related Blastocladia have narrow cylindrical tubular structures in the thick wall that open into minute pits on the surface of the cells (Fitzpatrick, 1930, p. 131). No evidence of such tubes or pits was seen in these hyaline cells in thin sections, although a feature of similar type could conceivably have been responsible for the peculiar wall structure of the Oval Spore Type B specimen shown on plate 14, figure 4 .

An alternative interpretation is that these fossils represent spores of an ascomycete, a dominantly terrestrial fungal group considered by most workers to be a more advanced evolutionary form than the phycomycetes. Spores in ascomycetes include types that do not have porous walls but are otherwise strikingly similar to the Alaska fossils. However, to postulate relation of these fossils with the ascomycetes would require that the organism producing them is not preserved in any recognizable manner in the matrix, because Cylindromyces does not resemble known ascomycetes, and the other fossils in this shale are not likely to be related to them. However, it would be presumptive to insist that these structures do not represent ascomycetes simply because parent mycelia are not recognizably preserved or because the presently known modern and fossil records are lacking a comparable occurrence. Therefore, in the absence of convincing evidence that these oval structures were formed by Cylindromyces, it appears best for now to classify them on the basis of morphology in the scheme proposed for fungal spores by Elsik (1976) in order to emphasize their unique nature in the biota at A-1408. Oval cells that occur in the Eagle area at A-1386 include individuals with dimensions similar to those at A-1408, but they differ in having a thin wall and a much greater range of lengths.

Occurrence.-A-1408, undivided sedimentary rocks unit, Takoma Bluff, Woodchopper area.

\section{Oval Spore Type B}

Plate 13, figures 4-6; plate 14, figure 4

Description.-Unicellular, oval with rounded ends, 19 by $31 \mu \mathrm{m}$ to 21 by $35 \mu \mathrm{m}$ (three specimens measured); spore wall with fine, evenly sculptured surface; internal structure unknown.

Discussion.-Three structures similar to Oval Spore Type A, which occur in the same sample, have rugose wall surfaces. In these three specimens, the rugosity has a hexagonal pattern not unlike the appearance of multiunits of the co-occurring Sphaerocongregus, in which acid maceration has produced a honeycomb texture (pl. 14, figs. 1,2). Breaks in the walls of specimens seen in figures 5 and 6 of plate 13 suggest, however, that these oval structures are not cell aggregates but are relatively thin-walled cells with featureless internal areas and sculptured surfaces. One specimen seen under scanning electron microscopy (pl. 14, fig. 4) has pronounced surface texture that contrasts markedly with others seen in this mode (pl. 14, figs. $3,5,6$ ). The faint indication of a pattern in the material of this poorly preserved specimen may indicate affinity with Type B.

Occurrence.-A-1408, undivided sedimentary rocks unit, Takoma Bluff, Woodchopper area.

?FUNGI

?Fungi Type A

Plate 2, figures 7,8

Description.-Filaments apparently nonseptate, 5 to $30 \mu \mathrm{m}$ in diameter, as long as $198 \mu \mathrm{m}$ (incomplete); branching at low angle; wall thickness, internal structure, and reproductive mode not known.

Discussion.-Three elongate structures of biogenic origin and composed of very dark, amber-colored hyaline material were found in one of the black layers in the maroon siliceous shale beds on the Tatonduk River. These are clearly fragmental, broken across the original long axis. One specimen (pl. 2, fig. 7) is $30 \mu \mathrm{m}$ wide throughout most of its length and has a narrower portion that has a ragged edge and appears to represent only part of the original filament. A second specimen, $17.3 \mu \mathrm{m}$ wide and $98 \mu \mathrm{m}$ long, is slightly bent but without evidence of fracture. The outer surfaces of these two specimens, although not well preserved, appear to have been smooth and straight. The third specimen (pl. 2, figure 8), $5 \mu \mathrm{m}$ wide and $95 \mu \mathrm{m}$ long, has a short branch essentially the same width as the main axis. The outer margin of this specimen 
is faintly undulating rather than straight. At high magnification and in strong light, these structures appear hyaline and entirely nongranular. No good evidence for septa or other internal structure was seen, and thickness of the outer wall could not be confirmed.

Despite the poor preservation and fragmental nature of these three specimens their biogenicity is not seriously doubted. They contrast sharply with the rare coccoid cells and the numerous smaller, subrounded patches of brown material preserved in the black cherty layers in the red beds. The apparent absence of septa or remains of included cells and branching habit, together with the probably chemically resistant nature of the walls, favors the interpretation that they represent fungal rather than cyanobacterial remains. Fungal filaments of comparable morphology but smaller diameter have been illustrated by Krumbein (1983) from iron-rich laminates in recent shelf sediments, and fossil fungi in iron stromatolites in Germany have been reported by Kretzschmar (1982).

Occurrence.-A-1387, basalt and red beds unit, Tatonduk River, Tatonduk area.

\section{?Fungi Type B \\ Plate 5, figures $1-8$}

Description.-Elongate, tapering, typically straight tubular structures about 2.5 to $9.5 \mu \mathrm{m}$ in diameter and up to $625 \mu \mathrm{m}$ long (incomplete); branching irregular, typically at high angle; outer wall smooth or with short, bract-like projections; apparently associated with originally rounded structures that may be attached to main axis by short stalk; internal structure uncertain, septa may have been present.

Discussion.-These unusual and highly varied fossils are randomly distributed in very fine grained, medium-gray, cherty shale. They are typically opaque, but occasional incompletely replaced specimens suggest that they are remains of an originally tubular structure. Most specimens are incomplete, preserved as one to several fractured linear structures that are widely separated in the matrix from other specimens. Gradual tapering, to a very fine point in some specimens, is typical, and occasional individuals appear to taper in two directions. The close association of filaments of different diameters and the lack of any apparent relation between increased length and increased diameter do not support interpretation of these as more than one species, although a few specimens of notably large diameter could represent an additional taxon.

The strong tendency for these fossils to be straight rather than curved, and to break perpendicular to the long axis, suggests a fairly rigid original material. In the apparently best preserved specimens, in which there are no overgrowths of replacement minerals, the outer surface appears smooth. If incompletely replaced specimens can be taken as indicative, the outer wall is about $2 \mu \mathrm{m}$ thick in a filament that is $625 \mu \mathrm{m}$ in preserved length. Although most specimens are completely replaced by dull black material, a few individuals lack part of the outer layer and, in reflected light, reveal smooth-surfaced axial zones replaced by a dull gold-colored metallic mineral, presumably pyrite. Whether these organisms were originally septate could not be confirmed. There is a tendency for disjunction of adjacent parts of filaments in a manner that could reflect septation. Some specimens appear jointed rather than curved (pl. 5, figs. 1, 3), whereas postmortem fracturing may account for apparent septation in other cases (pl. 5, fig. 6).

Unusual features of these fossils are the bract-like projections and the apparently associated subspherical bodies. The specimen shown in plate 5 figure 4 , reveals the nature of the projections particularly well. They range from 4 to $10 \mu \mathrm{m}$ in length, are somewhat pointed, and are clearly outgrowths from the main axis. This specimen also preserves an unusual form of branching, considerable range in diameter of filaments, and several of the subspherical bodies. Placement of the subspherical bodies with respect to the filaments and branches in this and several other specimens suggests original close association rather than random, fortuitous secondary proximity. In other specimens, the subspherical bodies may lie at the ends of pieces of filament or separated from filaments in such a way that original spatial arrangement is less certain. Occasional patches of similar material, without nearby filaments, are randomly scattered in the matrix. These patches tend to be more angular than the bodies associated with the filaments and have a much larger size range. In a few instances, bodies associated with filaments appear to have been attached by a short stalk (pl. 5, figs. $1,2,4,6)$, but in most cases such structures either are not preserved or were not originally present.

Variations in the diameter and in the nature of branching, together with the presence of bract-like outgrowths and apparently associated rounded bodies in these fossils, suggest affinity with the fungi. A number of modern fungi exhibit all of these characteristics, and the stalked(?) round bodies, short projections, and varied manner of branching in the fossils are particularly reminiscent of modern phycomycetes. The placement of similar modern fungi within families and genera is based in part on the specific nature and manner of attachment of special reproductive bodies, which are not sufficiently evident in these fossils to permit a referral at that level. On the other hand, the distinct tendency for these fossils to be straight and presumably of originally rigid material is not a common characteristic of the fungi.

An alternative interpretation is that these fossils represent some unknown type of spicule-bearing organism. 
Poriferan spicules with bract-like projections are known in the lyssakid Hyalospongia, which include Early Cambrian forms. However, these Hyalospongia do not exhibit the manner of branching present in the fossils and are not associated with rounded bodies that can be compared with those in the fossils. Moreover, although spicules are abundant at other localities in the same shale sequence and are in some cases partly replaced with dark granular material, none of the hundreds of sponge spicules seen thus far is morphologically similar to these fossils, and all are considerably larger in size.

Occurrence.-A-1404, basalt and red beds unit(?), Washington Creek, Nation area.

\section{PORIFERA}

Incertae Sedis

Plate 7, figures 1-3

Discussion.-Dissociated, commonly incomplete and replaced spicules of probable poriferan origin are present in a number of shale horizons in Washington Creek. Replacement history of fossils in these beds is complex, and it is not confirmed whether the spicules were originally siliceous or calcareous. In many cases, finely granular dark material now present in or around the spicules prevents analysis of their mineral composition in polarized light, thus it seems most useful to simply list the range of morphologies represented, noting their distribution in the Washington Creek section (see text fig. 7). These occurrences are listed below according to interpreted original morphology and size. Preservation varies from clear silica to silica with an external rim of dark granular material or with a paler rim around a partially to completely opaque interior. In general, the manner of replacement is consistent within a given sampled horizon.

Stauract or hexact spicules 0.2 to $0.5 \mathrm{~mm}$ in diameter, rays to $1 \mathrm{~mm}$ long (complete?); A-1392, A-1393, A-1394, A-1395, A-1396, A-1401, A-1402, A-1403, A-1407.

Apparent hexact spicules 0.02 to $0.07 \mathrm{~mm}$ in diameter, to $2 \mathrm{~mm}$ long; A-1392, A-1394.

Large, tapering, apparent diactene spicules 0.08 to 0.16 $\mathrm{mm}$ in diameter, commonly to $2 \mathrm{~mm}$ long; one complete(?) ray $0.16 \mathrm{~mm}$ in diameter is $6.7 \mathrm{~mm}$ long; A-1392, A-1395, A-1402, A-1403.

Many specimens in A-1402 and A-1403 are seen as circular or oval cross cuts with smooth, apparently original margins; the largest of these is 0.24 to $0.34 \mathrm{~mm}$ in diameter, indicating that spicules having diameters to $0.24 \mathrm{~mm}$ are present. These larger spicules commonly exhibit some form of secondary(?) concentric layering and may be chancelloriids.

Occurrence.-Basalt and red beds unit(?), Washington Creek, Nation area.

\section{?PORIFERA}

Unnamed multirayed form

Plate 11, figures 7,8

Discussion.-Particularly distinctive fossils that may be poriferan include those shown in plate 11, figures 7 and 8 . These small forms have five slender rays in one plane and, in both available specimens, a sixth ray of the same dimensions that radiates from the center and lies just beneath, and nearly parallel to, the plane of the other five. Whether the sixth ray was originally attached perpendicular to the other five is questionable because in both specimens it can be traced, without evidence of breakage, to the margin of the overlying central area that obscures it. Although the specimen shown in figure 7 exhibits no evidence of more than six rays, the knob-like protuberance in the specimen shown in figure 8 could represent a suppressed or broken additional structure. There is no evidence of an axial canal in these small fossils, which are delicately preserved with a smooth-surfaced, clear siliceous outer layer surrounding finely granular dark material. Sutures have not been observed between the bases of the rays, and it appears unlikely that sutures were present because the outer clear layer is smooth and distinct in the web-like junction between adjacent ray bases and because the underlying granular material has no evident break there.

If the clear silica layer represents an original spicular ray wall and the granular core represents a ray cavity, factors that would support interpretation of these fossils as spicules referable to the Chancelloriidae, it is necessary to postulate that an original sutured structure has been obliterated and recrystallized, leaving very smooth external surfaces, and that the ray cavities have been secondarily suffused with a homogenous mixture of silica and granular material. In this interpretation, which is considered unlikely, these Alaska specimens could represent a form close to Archiasterella antiqua, described by Sdzuy (1969) from the Lower Cambrian of Spain. An alternative explanation is that these specimens represent a different sponge(?) group having nonsutured, polyactine, solid spicules. From a preservational standpoint, however, this interpretation is also open to question because these specimens occur in the same thin section as the larger Brabbinthes churkini and rounded to wedge-shaped bodies described below as Incertae Sedis Type C. Problems in the interpretation of those fossils are discussed in the description of them, but it should be noted here that, 
although the larger forms are composed of clear silica envelopes surrounding granular central areas obviously similar to the small stellate structures, the larger forms cannot be referred to the Porifera with confidence, and the small, spherical, probable protistan Type F fossils of strikingly similar composition from Takoma Bluff clearly cannot be referred to the sponges.

Occurrence.-A-1392, basalt and red beds unit(?), Washington Creek, Nation area.

\section{Family CHANCELLORIIDAE Walcott, 1920}

Discussion.-As proposed by Walcott in 1920, this family included only the genus Chancelloria. Doré and Reid (1965) added their newly described Allonnia and Eiffelia Walcott, 1920, to the family and emphasized the unique sutured construction at the bases of the rays in the three genera. In a more detailed analysis of these sponges, Sdzuy (1969) suggested raising the group to ordinal rank and added newly described species of Eiffelia and Chancelloria as well as the new genus Archiasterella, all based on material from Spain and Morocco. All of these taxa, and additional Chancelloria species from Siberia described by Zhuravleva and Korde (1955), are of Cambrian age, and all are interpreted to have thin-walled hollow spicules with sutured ray bases. Rigby and Nitecki (1975) proposed expansion of the family to include sponges having generally similar solid polyactine spicules with unsutured ray bases; by virtue of referral to the group of Ordovician and Pennsylvanian forms with spicules of the latter type, they extended the range of the Chancelloriidae into the late Paleozoic. These authors suggested an evolutionary progression in which thin-walled, sutured spicules of the Cambrian chancelloriids gave rise to sponges with unsutured (or questionably sutured) solid spicules. They inferred that this change took place by early postCambrian time, as reflected in their inclusion of the Ordovician genus Toquimiella from Nevada, which has unsutured spicules.

The evolutionary and age implications of the presence or absence of sutured spicules and large ray cavities presents an interesting problem in the Washington Creek biotas because these include a wide variety of polyactine, chancelloriid-type spicules. Some of them are inflated and have clear evidence of sutured bases, thin walls, and large ray cavities. Others, also inflated, show no evidence of sutured rays and appear to have a narrow axial canal rather than a large ray cavity. A third type is otherwise similar to the latter but is not inflated and has no evidence of an axial canal. Preservation varies from shale to shale in the Washington Creek beds, and preserved forms include spicules now composed entirely of silica or of silica intermixed with calcite or organic material or both. Inasmuch as all of the spicules are dissociated, and thus provide no evidence of the morphology of the parent organism, the spicules are described below according to their general nature, in full recognition that an unknown number of parent taxa is probably represented. As pointed out by Rigby (1978, p. 1338, and written commun., 1975), chancelloriid spicules increase in size upward from the sponge base, and second- and third-order spicules may be much smaller than first-order spicules in a single organism; thus, size alone is probably not taxonomically significant. In addition to the types of spicules described under this heading (some of which may not belong to the Chancelloriidae), many of the larger, tapering spicules referred herein to Porifera Incertae Sedis could be chancelloriids. A suggestion was made by Bengtson and Missarzhevsky (1981) that chancelloriid spicules are, with several other early enigmatic metazoan fossils, representative of a separate major group of nonporiferan affinity for which the authors proposed the class-level name Coeloscleritophora.

\section{Genus CHANCELLORIA Walcott, 1920}

Chancelloria sp.

Plate 6; figures 1-3, 6, 7

Description.-Typically large spicules with thin wall and large ray cavity, up to nine tapered, curved tangential rays and one proximal ray; maximum tangential ray diameter $0.35 \mathrm{~mm}$ and length $0.7 \mathrm{~mm}$ (incomplete); rays sutured at base, arranged around central disc about 0.55 $\mathrm{mm}$ in diameter.

Discussion.-Description of these spicules is based on one polyactine specimen in which ray arrangement is reasonably certain (pl. 6, figs. 6, 7, and text fig. 12) and on several less-complete specimens of obviously similar nature and distinctive appearance. Suturing of ray bases is unquestioned in these spicules in which, despite the complex replacement history, the walls can be seen to extend around the individual ray bases. The original spicule surface probably is not preserved, because the outer margin, typically a thin clear silica layer, closely follows the outer surface of dark, densely granular underlying material which is so irregular that it is highly unlikely to faithfully reflect the original outer surface. The alternative interpretation, that the outer clear silica layer is the ray wall (and the dark layer part of the ray cavity), is not persuasive because the clear layer cannot be convincingly traced into the suture zones and around the individual ray bases. Rounded light spots seen in the dark layer may not reflect original morphology; these spots are single or coalesced pale areas of varying diameter, with or without included dispersed granular material. Most spots appear nearly spherical, but in a few instances they can be traced through successive focal depths as channels. Angular pale 
spots seen in the dark layer are secondary calcite rhombs, and larger pale areas where spicule structure is obliterated consist of a mosaic of calcite grains. Elsewhere in the internal area of the specimen shown on plate 6 , figures 6 and 7, dark, finely granular, mottled-appearing material is pervasively intermixed with a mosaic of very fine grained silica.

The two longer rays and a shorter one to the left in the specimen shown in plate 6 , figures 6 and 7 , and the specimen shown in figures 1-3 appear to have some sort of chamber near the base of the ray. Although these are ill-defined and may well represent an artifact of preservation, there is some evidence that they are made of wall material, as discussed below. It is not certain whether the

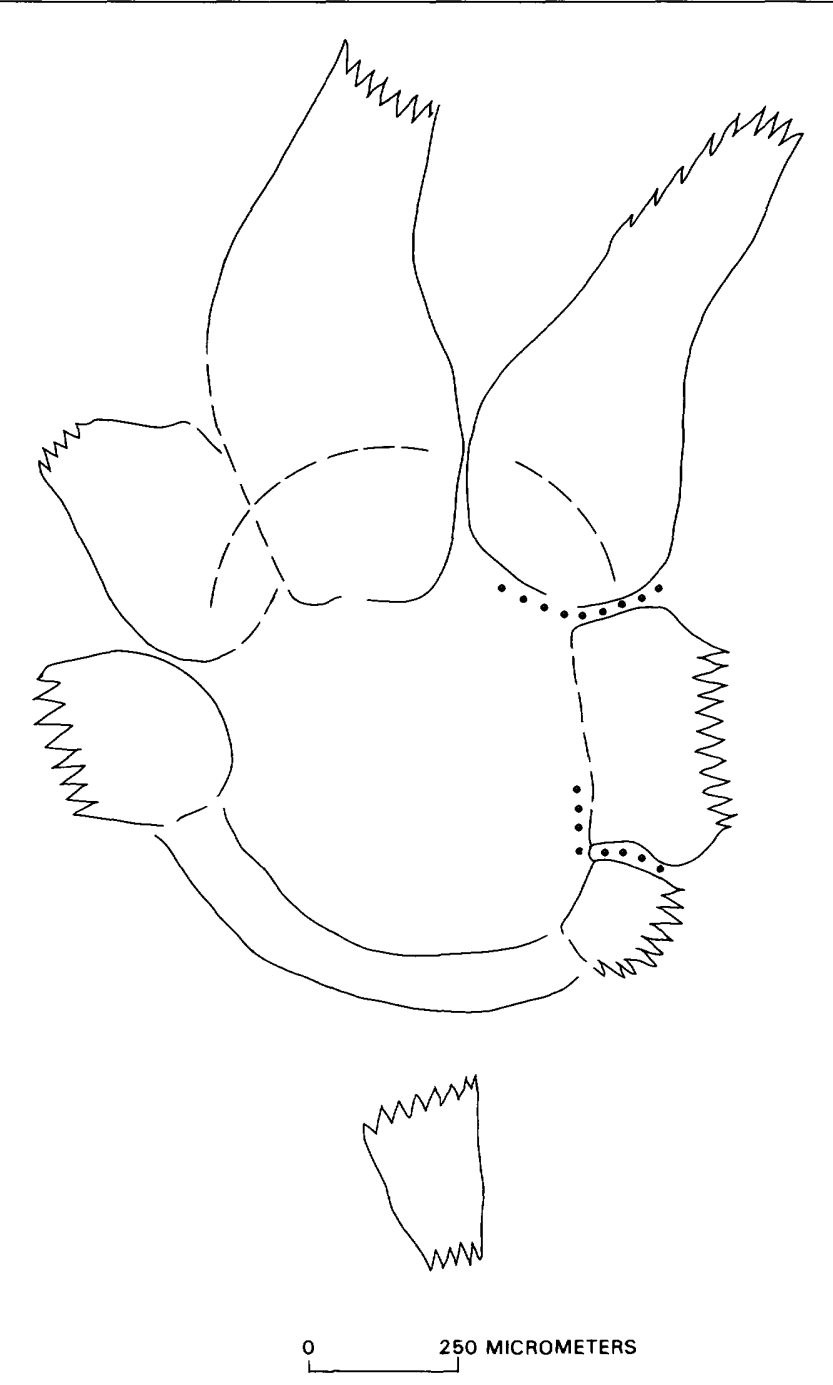

FIGURE 12.-Structure of multirayed chancelloriid spicule illustrated in plate 6, figures 6, 7. Dashed lines indicate apparent margins of ray walls and chambers(?) in bases of rays. Dotted lines show location of fiber-like structures in vicinity of ray bases. polyactine spicule, shown also in text figure 12 , has a proximal (or distal) ray. The roughly triangular dark piece shown at the bottom of the specimen appears to be associated with the sutured rays and is oriented in the manner expected if it represents a proximal ray, but it could be a piece of broken tangential ray lying fortuitously in this position. However, the spatial arrangement of rays in the specimen shown in figures 1-3 suggests that the longer one is a proximal (or distal) ray and the shorter one, at a right angle, is a tangential ray.

An intriguing feature of these and other fragmentary specimens is the fibrous appearance of the ray wall (pl. 6, fig. 2). The essentially parallel fibers are closely spaced and tend to be directed outward and distal to the ray surface. Although poorly preserved and difficult to see, they are present in all wall material. The triangular piece mentioned above (shown at the bottom in text fig. 12), has fibers arranged as would be expected if it is interpreted to be perpendicular to the circle formed by the bases of the rest of the rays. Fibrous walls have not been reported in chancelloriid spicules, thus the possibility that those seen in the Alaska material are not of primary origin must be considered. However, the fact that they exhibit a very consistent pattern with respect to the ray wall indicates that the original nature of the wall is somehow reflected in the preservation seen. Alternatively, postmortem parallel fractures now lined with finely granular dark material, or recrystallization resulting in granule-coated silica layers, could explain the pattern.

Whether or not the ray wall was originally fibrous, more discrete fibers are definitely present elsewhere in the spicule. These fibers are about 1.2 to $2.5 \mu \mathrm{m}$ in diameter and are typically dark, sinuous, loosely arranged strands. They lie in the suture zone between adjacent ray bases and can, in several areas, be seen to pass along the ray base around the periphery of the central disc. They are also present, although less prominent, along the curving distal walls forming the chambers(?) at the bases of the rays mentioned above. The clear silica channels in suture zones in which these fibers can be seen are 7 to $8 \mu \mathrm{m}$ wide; they are fairly straight and can be traced from ray junctions on the outer surface to the periphery of the central disc, which is now mostly filled with secondary calcite. Occasional fibers of similar nature are present in the internal ray cavity of the specimen shown in figures 1-3 of plate 6 , and they are present in many, typically wedgeshaped fragments otherwise similar to the more intact specimens (pl. 6, figs. 4, 5, and pl. 8, fig. 1).

Spicules in chancelloriids were earlier thought to be siliceous but are now generally accepted to be calcareous (see Sdzuy, 1969, p. 117-118). If the latter is correct, the Washington Creek specimens must have been first pervasively replaced with silica, after which calcite was formed in the spicules as discrete rhombs or, in some 
areas, as micrite, completely replacing the siliceous and organic material and obliterating spicular morphology. In areas where this obviously secondary calcite is not present, the spicule is composed entirely of dark organic(?) material and very fine grained silica.

Sdzuy (1969) suggested that the ray cavity of chancelloriids was filled with spongin and that strands of this material passed through central basal pores, thus providing a connection between individual spicules and greater strength to the spicular network. In the Alaska specimens, basal pores are not identified in the central disc or in individual rays, unless the apparent breaks in the bases of the rays seen in plate 6 , figure 1 , which are not central, represent basal pores. Fibers that are present in the Alaska material are found not in these possibly original openings but rather in the suture zones between adjacent rays. A critical question is whether the fibers in these fossils represent indigenous strands or a secondary phenomenon. Fiber-like structures in the dark layer apparently representing the ray wall are so consistent in size, parallel arrangement, and orientation with respect to the wall as to suggest an originally fibrous structure of organic or inorganic material. Although the strands present in the sutures and occasionally in the ray cavities may have a different origin from those in the ray wall, they are preserved in a similar manner and certainly are intimately associated with the fossils. Such strands are not present in these shales except in obvious spicules or in rounded to angular clasts. In many of the clasts the fibers are associated with dark material indistinguishable from that of the spicule wall (pl. 8, fig. 1). However, other clasts containing strands do not have such material (pl. 8, fig. 5). Some of these, in which the dark strands are highly sinuous and appear to be arranged differently from those in clasts also containing dark spicule(?) wall material, may reflect downslope transport from shallower-water, filamentous-algal-preserving beds.

Occurrence.-A-1395, basalt and red beds unit(?), Washington Creek, Nation area.

\section{?Chancelloria Type A \\ Plate 7, figure 4}

Discussion.-Spicules of polyactine habit that have smooth-surfaced inflated rays are included under this heading. These spicules occur in a number of Washington Creek shale horizons, in which they are typically preserved as polycrystalline silica with or without admixed calcite or dark granular material. They are commonly seen only as partial rays, but a few more-complete spicules have been observed. One of these is a distinctive polyactine form occurring at A-1395 with numerous fragments that appear to represent the same taxon. The spicules range in diameter from 90 to $120 \mu \mathrm{m}$ and are preserved as pale silica with a thin outer film of very fine grained, dark granular material, presumably an iron compound. No evidence of sutures between ray bases or of ray cavities or axial canals are discernible, but the specimen illustrated in plate 7 , figure 4 , is particularly reminiscent of ?Chancelloria of Zhuravleva and Korde (1955, fig. 18) from the Lower Cambrian of the Siberian Platform.

Occurrence.-A-1392, A-1395, A-1402, basalt and red beds unit(?), Washington Creek, Nation area.

\section{?Chancelloria Type B \\ Plate 7, Figures 5-8}

Description.-Whorl-like structures 0.2 to $0.3 \mathrm{~mm}$ in size, composed of four to six(?) curved, slightly tapering elements 22 to $26 \mu \mathrm{m}$ wide.

Discussion.-Four specimens of these enigmatic structures occur with numerous large spicules in medium-gray cherty shale in Washington Creek. Two specimens exhibit four ray-like elements, and the other two have two distinct rays and an uncertain number of possible additional rays. They are preserved as clear silica within oval areas that are paler than the matrix, a phenomenon that may reflect presence within the ovals of additional elements that cannot be brought into focus. Individual elements appear to radiate from a central point, forming a slightly to moderately open whorl that lacks a ray perpendicular to the base. The surfaces of the elements are smooth, and the distal end is evenly rounded and distinct. Sutures are not apparent between the proximal ends of adjacent elements, but slight separation in one specimen (pl. 7, fig. 5) could reflect this type of organization. The suggestion here that these fossils are poriferan is based on their occurrence in a spicule-rich bed, in which other types of organisms have not been recognized, rather than on their obvious similarity to currently described poriferan skeletal elements. In the absence of evidence either of cavities in the rays or of sutured structure, referral of these specimens to the Chancelloriidae must be regarded as conjectural.

Occurrence.-A-1402, basalt and red beds unit(?), Washington Creek, Nation area.

\section{COELENTERATA \\ Class ANTHOZOA \\ Genus TABULACONUS Handfield, 1969}

Tabulaconus kordeae Handfield, 1969

Plate 18, figure 3

Discussion.-Cylindrical to conical tabulate fossils occur with abundant archeocyathids in the Lower Cambrian Adams Argillite east of the Yukon River. Specimens I have seen come from locality A-922 south of the Taton- 
duk River (fig. 2), and similar material is reported in the Adams Argillite on the north bank of the Tatonduk River (R.A. Gangloff, written commun., 1979). Possible occurrence of Tabulaconus kordeae in the area was mentioned by Handfield (1969, p. 782), but no illustration, formational assignment, or locality information was provided. The specimen shown on plate 18 is typical of material at A-922. Preliminary examination strongly suggests referral to Tabulaconus, described by Handfield (1969) from the Lower Cambrian of northwest Canada.

Occurrence.-A-922, Adams Argillite, Tatonduk area.

\section{?ARTHROPODA}

Type A

Plate 9, figure 4

Discussion.-Two specimens of probable arthropod affinity have been observed in shales from Washington Creek. One of these, a curving micritic structure $2.5 \mathrm{~mm}$ long and 40 to $75 \mu \mathrm{m}$ wide (pl. 9, fig. 4), is interpreted as a section of a replaced carapace. It has an abruptly recurved end of a type commonly reported in trilobites, but this obviously could represent any type of arthropod in which the carapace is similarly recurved. An alternative interpretation is that this specimen, which exhibits no laminar structure, is a section cut through a nonarthropod shelly fossil such as Aldanella, Pelagiella, or other strongly curved form reported from the Early Cambrian (Matthews and Missarzhevsky, 1975). Although this Washington Creek specimen appears to be a single long piece, examination in polarized light reveals that the structure is very indefinite in the area of the gentle curve in the middle and may, in fact, represent two fortuitously aligned pieces of thin shell. The hook-like end is also poorly defined when viewed in polarized light.

Occurrence.-A-1395, basalt and red beds unit(?), Washington Creek, Nation area.

\section{Type B}

Plate 9, figures 1-3

A second, more probable arthropod fragment occurs as a thin flake of noncalcified, presumably chitino-phosphatic material $0.6 \mathrm{~mm}$ long and about $20 \mu \mathrm{m}$ thick. External surfaces are smooth to ragged, and the ends are obviously torn. The specimen appears yellowish in transmitted light and is composed of as many as seven homogeneous layers defined by darker, presumably membranous films $0.2 \mu \mathrm{m}$ thick. The layers are perforated by canals about $2 \mu \mathrm{m}$ in diameter that are generally perpendicular to the long axis of the fragment and are open on both ends. The tendency for these canals to appear in alternate arrangement at increasing focal depth suggests that the canal openings result in evenly offset rows of pores on the inner and outer surfaces. Adjacent canals in what is interpreted as one row are about $7 \mu \mathrm{m}$ apart.

Porous, laminated chitinous material is common in arthropod cuticle; however, this specimen provides no morphologic evidence on which to suggest further taxonomic affinity. It is not certain whether the fragment represents the trilobites, some other arthropod group, or even a nonarthropod metazoan.

Occurrence.-P.E. Cloud field locality 1 of 16/6/75, UCSB 544(17), basalt and red beds unit(?), Washington Creek, Nation area.

Type C

Plate 18 , figures 4,5

A complex possible arthropod fossil occurs in beds mapped by Brabb and Churkin (1969) as the undivided sedimentary rocks unit in the Woodchopper area. This curious structure is composed of nearly hyaline, pale- to dark-yellowish-brown material representing the crushed wall of an apparently complex organism with appendages. The wall varies in thickness from 5 to $7 \mu \mathrm{m}$ and has thin dark lines defining paler lamellae 0.2 to $1 \mu \mathrm{m}$ thick. Individual lamellae are easily traced along the curved and folded wall. Several oval-shaped parts exhibit an inner nonlamellar layer 4 to $5 \mu \mathrm{m}$ thick surrounding a central area having a crushed membrane-bounded tube. There is no evidence of pores through the wall or of surface texture. Although this specimen is grossly similar to Type B, the complex morphology and more numerous and more closely spaced nonporous lamellae in Type C clearly distinguish the two.

Occurrence.-P.L. Brown field locality EU 3 of 1981, undivided sedimentary rocks unit, Woodchopper area.

\section{METAZOA INCERTAE SEDIS}

Brabbinthes churkini Allison, 1975

Plate 10, figures 1-5

Discussion.-This unique fossil occurs in one of the very fine grained, homogeneous, cherty black shale beds in Washington Creek. It was originally interpreted (Allison, 1975) as a silicified flatworm on the basis of its distinctive shape and internal structure and in view of cooccurring, similarly preserved subrounded fossils thought to be transverse sections of nonshelled organisms (see Incertae Sedis Type C). Support for the unexpected lack of distortion during preservation of such a soft-bodied organism as a flatworm was taken also from the equally undistorted, co-occurring colonial Protista Incertae Sedis Type G, in which the original outer wall was almost certainly not mineralized and probably was not cuticularized. 
Cloud and others (1975) later suggested that Brabbinthes could represent a poriferan spicule of unusual morphology. Undoubted spicules are present in great abundance in several different shale horizons exposed in Washington Creek and include a considerable range in size, shape, and preservation, although none of the hundreds of spicules seen look like Brabbinthes. Among those observed, some of the chancelloriids are most similar to Brabbinthes in that they have proximally swollen rays; however, these are sutured spicules with fibrous-appearing walls and with large ray cavities rather than the narrow axial canals present in Brabbinthes (pl. 10, figs. 1, 5). Other possible candidates for comparison are inflated spicules preserved as polycrystalline silica or silica-carbonate mosaics with or without included opaque material and without clear evidence of internal structure, although none of the dozens of such spicules seen has a shape comparable to Brabbinthes. Occasional spicules with narrow axial canals of persistent width as in Brabbinthes are present in other Washington Creek shales, but these invariably have long slender rays. However, interpretation of Brabbinthes as a spicule offers an explanation for its smooth-walled nature and stauract organization. In this interpretation, the thin, clear, outer layer would be assumed to be the original outer spicule layer rather than secondarily added silica because in Brabbinthes this layer, and not the underlying granular material, defines a spicule shape. This interpretation is consistent with the composition of the co-occurring, smaller stellate fossils described herein as unnamed multirayed ?Porifera in which, however, the rays are slender and lack axial canals and there are five rays in one plane.

As described in detail in Allison (1975), there are distinctive nongranular areas in the interpreted anterior region of Brabbinthes. Why this otherwise highly homogeneous and persistent granular zone should contain such distinctive features, if this fossil is a spicule, is not known. The paired parallel channels that angle downward along the midline above the axial canal (pl. 10, figs. 2-4), and the distribution of the granular zone in the interpreted anterior region as a whole, are particularly difficult to explain as secondary phenomena in view of the fact that this fossil, whatever its origin, is preserved in considerable detail. Presumably these structures reflect irregularities in the substance of the granular zone before or during original postmortem silicification. Such irregularities have not been observed in the many Washington Creek spicules that contain granular opaque material, and their location and arrangement in Brabbinthes is consistent with their earlier interpretation as lacunae in the mesenchymal layer of a soft-bodied organism. However, interpretation of them as strictly fortuitous features in an internal zone of a mineralized, uniquely shaped spicule cannot be ruled out.

Persistent search in over one hundred thin sections representing different shale horizons in the Washington
Creek beds not only failed to locate specimens comparable to Brabbinthes and of the co-occurring protistan and crosscut metazoan(?) fossils referred to Incertae Sedis Type C at A-1392 but, in fact, served to emphasize their uniqueness. A conclusion that Brabbinthes is a stauract or hexact poriferan spicule of atypical shape and preservation can certainly accommodate some of its morphologic features but fails to convincingly explain others.

Occurrence.-A-1392, basalt and red beds unit(?), Washington Creek, Nation area.

\section{INCERTAE SEDIS \\ ?Oldhamia \\ Plate 18, figure 1}

Description.-Linear impressions about $1 \mathrm{~mm}$ wide and 7 to $10 \mathrm{~mm}$ long, typically slightly undulatory, apparently not extending downward into sediment; traces isolated or arranged in subparallel, faintly radiating fan-shaped groups having as much as $12 \mathrm{~mm}$ maximum spread.

Discussion.-These shallow traces are described from a single bedding plane on a 60 - by $90-\mathrm{mm}$ piece of dark, greenish-gray argillite from Edwards Creek, $25 \mathrm{~km}$ east of Takoma Bluff. The traces are generally similar to Oldhamia, originally described from the Middle(?) Cambrian of Ireland and now known in Late Proterozoic(?) and Cambrian rocks elsewhere in Europe and North America. The definitive feature of Oldhamia is the arrangement of small linear impressions in a distinctive fan or circularradiating pattern. Consistent morphology in a number of Oldhamia occurrences has led to definition of several species, based on the shape and arrangement of the linear elements. The traces presently available from Edwards Creek are less organized into a recognizable fan shape than previously described species and include isolated linear impressions that are not part of any fan-shaped structure. The isolated traces are, however, of the same size and appearance as those in the subparallel group and probably have the same origin.

Oldhamia is now generally accepted to represent wormburrowing activity (Crimes, 1975). Several occurrences have been previously reported from east-central Alaska, including two in the eastern Nation area from faultbounded blocks interpreted to be correlative with the Lower Cambrian Adams Argillite (Churkin and Brabb, 1965; Brabb and Churkin, 1969). In those occurrences (pl. 18, fig. 2), individual linear traces are straighter, and their arrangement into fan shapes is more marked than in the available specimens from Edwards Creek. Positions of the Edwards Creek traces are clearly much less organized than those of $O$. radiata, $O$. antiqua, and other traces referred with confidence to Oldhamia. Photographs of the Edwards Creek specimens were examined by T.P. Crimes, who suggested (written commun., 1978) 
that they be referred to the genus with question and who confirmed that no Oldhamia occurrences known to him are older than Cambrian. However, more recent reports of the trace fossil in northwest Canada by Hoffman and Cecile (1981) include occurrences in rocks thought to be Late Proterozoic in age.

Evolution in this group, as it might be seen in terms of increasingly complex and (or) well-organized arrangement, has not been comprehensively analyzed. It is not certain at present if the notable lack of consistent arrangement of the Edwards Creek traces indicates a primitive stage of evolutionary development, although this possibility should not be ruled out, especially as it is not confirmed at present that the Edwards Creek traces are as young as Cambrian.

Occurrence.-63ABa4176, undivided sedimentary rocks unit, southeastern Woodchopper area.

\section{Incertae Sedis Type A}

Plate 9, figure 5

Description.-Multicellular (or multichambered), subrectangular, about $0.5 \mathrm{~mm}$ in size, composed of four roughly oval, closely packed subunits with silica rims about $12 \mu \mathrm{m}$ thick; two of four subunits contain round, dark granular patches 75 and $58 \mu \mathrm{m}$ diameter; more evenly granular dark material is present around part of outer margin and between adjacent subunits.

Discussion.-This apparently biogenic structure is represented by a single specimen. It is probably incomplete and is of uncertain affinity, but its organization and structure are very distinctive. In addition to the silica envelope around individual subunits, there appears to be an incomplete outer siliceous wall, shown at lower right in plate 9 , figure 5 . Orientation of silica grains within these layers is perpendicular to the margin of the subunits, but there is no preferred orientation of grains in the few silica patches present within the subunits.

The irregular dark granular patches intermittently present around and between the subunits look like altered organic material; these differ from the dark round areas inside the subunits in being generally finer and more evenly granular. The dark round areas are made up of minute grains in ragged patches and irregular short thread-like bits. Secondary dolomite grains within the subunits vary in size and have irregularly angular margins. These grains impinge closely on, but are not present within, the round dark areas. Other dark material within the subunits is generally confined to rims around the secondary dolomite grains but also includes two framboidal bodies.

Presuming that this specimen is biogenic raises the question of whether the clear borders around the subunits represent primary or secondary silica envelopes. These borders are not similar to the chalcedonic banding observed elsewhere at A-1395, in which concentric laminar structure is obvious and the prismatic arrangement of the outer layer in this fossil is definitely not present. Differences in granularity as well as in distribution between the dark material around the subunits and that within the round areas suggest different parent materials or differently controlled replacement processes. Material in the outer dark areas most closely resembles that seen in heavily replaced spicules, whereas that in the round areas is reminiscent of the irregular dark thready material present in the central areas of crosscut metazoan(?) fossils (referred to Incertae Sedis Type C) in A-1392. If the subunits represent cells, these round patches could represent the condensed remains of all of the original cytoplasmic material, or, less likely, they could represent nuclei or some other discrete, original, intracellular body.

The size of subunits in this enigmatic structure suggests animal rather than plant affinity; however, shape and size of the entire original structure are impossible to confirm inasmuch as only one specimen has been seen and it may be only a part of a larger structure. The subunits are clearly intimately associated, as can be seen by their complementary shape shown in the upper part in plate 9 , figure 5 , and the apparent connecting wall shown at the lower right. If the wall was not originally mineralized, it probably was firm because this structure occurs with abundant fragmentary spicules and other shelly debris that strongly suggest downslope transport.

Occurrence.-A-1395, basalt and red beds unit(?), Washington Creek, Nation area.

\section{Incertae Sedis Type B}

Plate 4, figure 11

Discussion.-Several specimens of apparent shelly material have been observed in thin sections prepared from one of the shales in Washington Creek. These are typically elongate, curving specimens ranging from 0.04 to $0.08 \mathrm{~mm}$ in thickness and as much as $1.5 \mathrm{~mm}$ in length. Most are micritic and show no evidence of original shell structure, but one is faintly layered now, if not originally. Most specimens appear to be unbroken, which, in view of their small size, indicates that they represent submacroscopic organisms. Whether these were originally chitinous or not is uncertain because the shale in which they occur exhibits an extremely complex replacement history. Part of one of these specimens is shown above the filaments in plate 4, figure 11.

Occurrence.-A-1395, basalt and red beds unit(?), Washington Creek, Nation area.

\section{Incertae Sedis Type C \\ Plate 11, figures 4-6}

Discussion.-Several enigmatic structures of probable biogenic origin occur in one of the Washington Creek 
shales with Brabbinthes, Protista Incertae Sedis Type G, and small stellate fossils described under ?Porifera as an unnamed multirayed form. Although differing somewhat from one another, they are all rounded to subrounded in shape and generally similar in size and preservation and thus are grouped under one heading for purposes of convenience. They are typically composed of a smoothsurfaced, clear siliceous outer layer surrounding a granular central area. One (pl. 11, fig. 4) is circular in shape, $53 \mathrm{~m}$ in diameter, and has an eccentrically located nongranular area inside. A second specimen (pl. 11, fig. 5) is slightly wedge shaped, $48 \mathrm{~m}$ in greatest diameter, and shows no differentiation of the granular interior. A third specimen (pl. 11, fig. 6) consists of a wedge-shaped granular area surrounded by a clear silica envelope that spreads in a bulbous fashion to form a smaller rounded extension. In this specimen the large granular area contains a nearly central darker patch and thus differs from the others in which the granular material is more homogeneous.

Biogenicity of these structures is probable because they are discrete and distinctive in the markedly homogeneous shale in which they occur and because they are very similar in appearance and in composition to the cooccurring Brabbinthes. The general appearance of the round specimens is reminiscent of Protista Incertae Sedis Type F (a persistently spherical, presumably planktonic fossil from Takoma Bluff) in which a thin, clear, siliceous outer layer surrounds a granular interior that may have nongranular central areas. In view of the generally similar, simple but nondiagnostic shapes of these structures and their occurrence with Brabbinthes, as well as the absence of any other similarities between the biotas at Washington Creek and Takoma Bluff, it appears most useful to consider them in relation to Brabbinthes to the extent that such consideration can provide any plausible clues to their origin. From this standpoint it seems reasonable to suggest that these enigmatic structures and Brabbinthes were made of similar original substances that were preserved in a similar, silica-rimmed fashion.

Brabbinthes was earlier interpreted (Allison, 1975) in relation to the platyhelminths and here in relation to a sponge(?) spicule. The specimen shown in plate 11, figure 4 , could represent a crosscut through a circular part of a Brabbinthes-like structure, although the nongranular internal area in this specimen is not central or of circular shape, as it appears to be in Brabbinthes. However, the specimens shown in figures 5 and 6 on plate 11 do not suggest cuts through any part of a Brabbinthes-like fossil unless the latter can be interpreted to have been originally noncircular or nonoval in cross section or originally soft enough to have been formed to these shapes either before or during fossilization. Distortion of a rigid siliceous or calcareous spicule to the shapes seen in Incertae Sedis
Type $\mathrm{C}$ would be difficult to explain because of the absence of fractures in these fossils. Chancelloriid spicules were hollow and may exhibit longitudinal collapse of the rays (Rigby, 1978), a phenomenon that might account for the shape of an indented specimen of Incertae Sedis Type C (not illustrated); however, chancelloriid affinity is questionable for Brabbinthes, which lacks the definitive morphologic features of those distinctive spicules. In order to pursue comparison of Incertae Sedis Type $\mathrm{C}$ with Brabbinthes, if the latter is a spicule, it is necessary to consider other types of sponges that presumably have solid and rigid spicules; however, because of the shapes of Type $\mathrm{C}$ fossils, this is an unsatisfactory solution to the question of the biologic affinity of these fossils.

Alternative interpretations are that (a) these specimens are not spicules (or represent spicules of an unknown type) and (b) their striking similarity in composition to Brabbinthes does not signal similar parent substance or a relation to this fossil. If the latter is correct, little useful speculation about the affinity of Type $\mathrm{C}$ can be made because of the nondiagnostic shapes and lack of comparability with other known forms. These specimens are clearly different from other fossils at Washington Creek and bear no resemblance to types known elsewhere except for their compositional similarity to apparent protistan fossils from Takoma Bluff, which are much more consistent in both shape and size.

Occurrence.-A-1392, basalt and red beds unit(?), Washington Creek, Nation area.

\section{REFERENCES CITED}

Aalto, K.R., 1971, Glacial marine sedimentation and stratigraphy of the Toby Conglomerate (Upper Proterozoic), southeastern British Columbia, northwestern Idaho and northeastern Washington: Canadian Journal of Earth Sciences, v. 8, no. 7, p. 753-787.

Allison, C.W., 1975, Primitive fossil flatworm from Alaska: new evidence bearing on ancestry of the Metazoa: Geology, v. 3, no. 11, p. 649-652. 1981, Siliceous microfossils from the Lower Cambrian of northwest Canada: possible source for biogenic chert: Science, v. 211, p. 53-55.

Allison, C.W., and Hilgert, J., 1986, Scale microfossils from the Early Cambrian of northwest Canada: Journal of Paleontology, v. 60, no. 5, p. 973-1015.

Allison, C.W., and Moorman, M.A., 1973, Microbiota from the Late Proterozoic Tindir Group, east-central Alaska: Geology, v. 1, no. 2, p. $65-68$.

1974, Pyritized microfossils and pyrite framboids: reply: Geology, v. 2, no 4, p. 202-203.

Allison, C.W., Young, G.M., Yeo, G.M., and Delaney, G.D., 1981, Glaciogenic rocks of the Upper Tindir Group, east-central Alaska, in Hambrey, M.J., and Harland, W.B., eds., Earth's pre-Pleistocene glacial record: London, Cambridge University Press, p. 720- 723.

Awramik, S.M., and Allison, C.W., 1980, Earliest Cambrian blue-green algal communities from the Yukon Territory of Canada [abs.]: International Geological Congress, 26th, Paris, 1980, Abstracts, v. 1, p. 198. 
Barghoorn, E.S., Meinschein, W.G., and Schopf, J.W., 1965, Paleobiology of a Precambrian shale: Science, v. 148, p. 461-472.

Beck, Sabine, 1963, Licht und elektronen mikroskopische Untersuchungen an einer spornbilden den Cyanophycee aus dem Formenkreis von Pleurocapsa fuliginosa Hauck [Light and electron microscope investigations on a spore-forming cyanophycee of the Pleurocapsa fuliginosa Hauck group]: Flora, v. 153, p. 194-208.

Bengtson, Stefan, and Missarzhevsky, V.V., 1981, Coeloscleritophora-a major group of enigmatic Cambrian metazoans, in Taylor, M.E., ed., Short papers for the Second International Symposium on the Cambrian System, 1981: U.S. Geological Survey Open-File Report 81-743, p. 19-21.

Bloeser, Bonnie, Schopf, J.W., Horodyski, R.J., and Breed, W.J., 1977, Chitinozoans from the late Precambrian Chuar Group of the Grand Canyon, Arizona: Science, v. 195, p. 676-679.

Brabb, E.E., 1967, Stratigraphy of the Cambrian and Ordovician rocks of east-central Alaska: U.S. Geological Survey Professional Paper $559-\mathrm{A}, 30 \mathrm{p}$

Brabb, E.E, and Churkin, Michael, Jr., 1965, Preliminary geologic map of the Eagle D-1 quadrangle, east-central Alaska: U.S. Geological Survey open-file report, scale 1:63,360.

1969 , Geologic map of the Charley River quadrangle, east-central Alaska: U.S. Geological Survey Miscellaneous Investigations Map I-573, scale 1:250,000.

Brabb, E.E., and Hamachi, B.R., 1977, Chemical composition of Precambrian, Paleozoic, Mesozoic and Tertiary rocks from east-central Alaska: U.S. Geological Survey Open-File Report 77-631, 166 p.

Cairnes, D.D., 1914, The Yukon-Alaska International Boundary, between Porcupine and Yukon Rivers: Geological Survey of Canada Memoir $67,161 \mathrm{p}$.

Chauvel, J.J., and Schopf, J.W., 1978, Late Precambrian microfossils from Brioverian cherts and limestones of Brittany and Normandy, France: Nature, v. 275, p. 640-642.

Churkin, Michael, Jr., 1973, Paleozoic and Precambrian rocks of Alaska and their role in its structural evolution: U.S. Geological Survey Professional Paper 740, $64 \mathrm{p}$.

Churkin, Michael, Jr., and Brabb, E.E., 1965, Occurrence and stratigraphic significance of Oldhamia, a Cambrian trace fossil, in eastcentral Alaska, in Geological Survey Research 1965: U.S. Geological Survey Professional Paper, 525-D, p. D120-D124.

Churkin, Michael, Jr., Foster, H.L., Chapman, R.M., and Weber, F.R., 1982, Terranes and suture zones in east central Alaska: Journal of Geophysical Research, v. 87, no. B5 p. 3718-3730.

Cloud, P.E., Awramik, S.M., Morrison, Karen, and Hadley, D.G., 1979, Earliest Phanerozoic or latest Proterozoic fossils from the Arabian Shield: U.S. Geological Survey Open-File Report 79-1186, 42 p.

Cloud, P.E., Moorman, M.A., and Pierce, David, 1975, Sporulation and ultrastructure in a Late Proterozoic Cyanophyte: some implications for taxonomy and plant phylogeny: Quarterly Review of Biology, v. 50, p. $131-150$.

Coker, W.C., 1923, The Saprolegniaceae: Chapel Hill, University of North Carolina Press, 201 p.

Crimes, T.P., 1975, The stratigraphic significance of trace fossils, in Frey, R.W., ed., The study of trace fossils: a synthesis of principles, problems, and procedures in ichnology: New York, Springer-Verlag, p. 109-130.

Doré, Francis, and Reid, R.E., 1965, Allonia tripodophora nov. gen., nov. sp., nouvelle Eponge dù Cambrien inférieur de Carteret (Manche) [Allonia tripodophora new gen., new sp., a new sponge from the Lower Cambrian of Carteret (Manche)]: Société Geologique de France, Compte Rendu Sommaire des Séances 1965, p. 20-21.

Downie, Charles, Evitt, W.R., and Sarjeant, W.A.S., 1963, Dinoflagellates, hystrichospheres, and the classification of the acritarchs: Stanford, Calif., Stanford University Publications in the Geological Sciences, v. 7 , no. 3,16 p.
Elsik, W.C., 1976, Fossil fungal spores, in Weber, D.J., and Hess, W.M., eds., The fungal spore: New York, John Wiley and Sons, p. 849-862.

Evenchick, C.A., Parrish, R.R., and Gabrielse, Hubert, 1984, Precambrian gneiss and late Proterozoic sedimentation in north-central British Columbia: Geology, v. 12, no. 4, p. 233-237.

Fitzpatrick, H.M., 1930, The lower fungi: Phycomycetes: New York, McGraw-Hill, $331 \mathrm{p}$.

Fritsch, F.E., 1971, The structure and reproduction of the Algae [reprint of 1935 edition]: London, Cambridge University Press, v. I, 791 p.; v. II, $939 \mathrm{p}$.

Gabrielse, Hubert, 1967, Tectonic evolution of the northern Canadian Cordillera: Canadian Journal of Earth Sciences, v. 4, no. 2, p. 271-298.

1972, Younger Precambrian of the Canadian Cordillera: American Journal of Science, v. 272, no. 6, p. 521-536.

Green, L.H., 1972, Geology of Nash Creek, Larsen Creek, and Dawson map-areas, Yukon Territory: Geological Survey of Canada Memoir $364,157 \mathrm{p}$.

Hallbauer, D.K., Jahns, H.M., and Beltmann, H.A., 1975, Morphological and anatomical observations on some Precambrian plants from the Witwatersrand, South Africa: Chamber of Mines of South Africa, Research Organization, Project GT1V03, Research Report 49/75, 19 p.; also, Stuttgart, Germany, Internationale Zeitscrift für Geologie, Geologishe Rundschau, v. 66, p. 477-491, 1977.

Hallbauer, D.K., and van Warmelo, K.T., 1974, Fossilized plants in thucholite from Precambrian rocks of the Witwatersrand, South Africa: Precambrian Research, v. 1, no. 3, p. 199-212.

Handfield, R.C., 1969, Early Cambrian coral-like fossils from the northern Cordillera of western Canada: Canadian Journal of Earth Sciences, v. 6 , no. 4 , p. $782-785$.

Hofmann, H.J., 1984, Organic-walled microfossils from the latest Proterozoic and earliest Cambrian of the Wernecke Mountains, Yukon, in Current research, part B: Geological Survey of Canada Paper 84-1B, p. 285-297.

Hofmann, H.J., and Cecile, M.P., 1981, Occurrence of Oldhamia and other trace fossils in Lower Cambrian(?) argillites, Niddery Lake map-area, Selwyn Mountains, Yukon Territory, in Current research, part A.: Geological Survey of Canada Paper 81-1A, p. 281-289.

Kalliokoski, J., 1974, Pyrite framboid: animal, vegetable, or mineral?: Geology, v. 2, no. 1, p. 26-27.

Kline, G.L., 1975, Proterozoic budding bacteria from Australia and Canada: Santa Barbara, University of California, M.A. thesis, 92 p. 1977, Earliest Cambrian (Tommotian) age of the upper Tindir Group, east-central Alaska [abs.]: Geological Society of America Abstracts with Programs, v. 9, no. 4, p. 448.

Knoll, A.H., 1982, Microfossils from the late Precambrian Draken Conglomerate, Ny Friesland, Svalbard: Journal of Paleontology, v. 56, no. 3 , p. 755-790.

Kretzschmar, M., 1982, Fossil fungi in iron stromatolites from Warstein, Rehnish massif, northwest Germany: Facies, v. 7, p. 237-260.

Krumbein, W.E., 1983, Stromatolites-the challenge of a term in space and time: Precambrian Research, v. 20, p. 493-531.

Loeblich, A.R., Jr., 1974, Protistan phylogeny as indicated by the fossil record: Taxon, v. 23, p. 277-290.

Loeblich, A.R., Jr., and Tappan, H.L., 1978, Some Middle and Late Ordovician microphytoplankton from central North America: Journal of Paleontology, v. 52, no. 6, p. 1233-1287.

Mansuy, Catherine, and Vidal, Gonzalo, 1983, Late Protozoic Bioverian microfossils from France: taxonomic affinity and implications of plankton productivity: Nature, v. 302, no. 5909, p. 606-607.

Matthews, S.C., and Missarzhevsky, V.V., 1975, Small shelly fossils of late Precambrian and early Cambrian age: a review of recent work: Journal of the Geological Society of London, v. 131, p. 289-304.

Mertie, J.B., Jr., 1930, Geology of the Eagle-Circle district, Alaska: U.S. Geological Survey Bulletin 816, 168 p. 
1933, The Tatonduk-Nation district, Alaska, in Smith, P.S., and others, Mineral resources of Alaska: U.S. Geological Survey Bulletin 836-E, p. 347-443.

Moorman, M.A., 1974, Microbiota of the Late Proterozoic Hector Formation, southwestern Alberta, Canada: Journal of Paleontology, v. 48 , no. 3 p. $524-539$.

Palmer, A.R., 1968, Cambrian trilobites of east-central Alaska: U.S. Geological Survey Professional Paper 559-B, 115 p.

Payne, M.W., and Allison, C.W., 1978, Precambrian and Cambrian rocks of east-central Alaska [abs.]: American Association of Petroleum Geology Bulletin, v. 62, no. 3, p. 553.

1981, Paleozoic continental-margin sedimentation in east-central Alaska: Geology, v. 9, no. 6, p. 274-279.

Perfil'ev, B.V., Gabe, D.R., Gal'perina, A.M., Rabinovich, V.A., Sapotnitskii, A.A., Sherman, É.É. and Trushanov, É.P., 1965, Applied capillary microscopy; the role of microorganisms in the formation of iron-manganese deposits: New York, Consultants Bureau, Special Research Report, 122 p. [translation of Rol' mikroorganizmov v obrazovanii zhelezio-margantsevykh ozernykh rud, 1964, Moscow, Akademiya Nauk SSSR, Savarenskii Laboratory of Hydrogeological Problems].

Raaben, M.E., ed., 1981, The Tommotian Stage and the Cambrian lower boundary problem: New Delhi, Amerind, 359 p., [translation of Tommotskii yarus i problema nizhnei granitsy kembriya, 1969, Moscow, Akademiya Nauk SSSR, Institute Geologii, Publication 206].

Rigby, J.K., 1975, Some unusual hexactinellid sponge spicules from the Cambrian Wilberns Formation of Texas: Journal of Paleontology, v. 49 , no. 2 , p. $412-415$.

1978 , Porifera of the Middle Cambrian Wheeler Shale, from the Wheeler Amphitheater, House Range, in western Utah: Journal of Paleontology, v. 52, no. 6, 1325-1345.

Rigby, J.K, and Nitecki, M.H., 1975, An unusually well preserved heteractinid sponge from the Pennsylvanian of Illinois and a possible classification and evolutionary scheme for the Heteractinida: Journal of Paleontology, v. 49, no. 2, p. 329-339.

Rippka, Rosemarie, Deruelles, Josette, Waterbury, J.B., Herdman, Michael, and Stanier, R.Y., 1979, Generic assignments, strain histories and properties of pure cultures of Cyanobacteria: Journal of General Microbiology, v. 3, p. 1-61.

Schopf, J.W., 1968, Microflora of the Bitter Springs Formation, Late Precambrian, central Australia: Journal of Paleontology, v. 42, no. 3, p. 651-688.

Schopf, J.W., Ford, T.D., and Breed, W.J., 1973, Microorganisms from the Late Precambrian of the Grand Canyon, Arizona: Science, v. 179, p. 1319-1321.
Sdzuy, Klaus, 1969, Unter- und Mittelkambrische Porifera (Chancelloriida und Hexactinellida) [Lower and Middle Cambrian Porifera]: Palaontologische Zeitschrifte, v. 43, p. 115-147.

Shepeleva, E.D., 1962, 1964, Rastitel'nyye(?) ostatki neizvestnoy sistematicheskoy prinadlezhnosti iz otlozheniy bavlinskoy serii VolgoUral'skoy neftenosnoy provintsii [Plant(?) fossils of unknown taxonomic position from the deposits of the Bavlinskaya series in the Volga-Urals oil province]: Doklady Akademiya Nauk SSSR, v. 142, no. 2 , p. $456-457$, Doklady-Earth Science Section, v. 142, p. $170-171$.

Tiffney, B.J., and Barghoorn, E.S., 1974, The fossil record of the fungi: Farlow Herbarium of Cryptogamic Botany Occasional Paper 7, $42 \mathrm{p}$.

Timoféev, B.V., 1970, Une découverte de phycomycetes dans le Precambrien [A discovery of phycomycetes in the Precambrian]: Review of Paleobotany and Palynology, v. 10, no. 1, p. 79-81.

Timoféev, B.V., German, T.N., and Mikhaylova, N.S., 1976, Mikrofitofossilii dokembriya, kembriya, i ordovika [Microphytofossils of the Precambrian, Cambrian, and Ordovician]: Izdatel'stvo Akademiya Nauk SSSR, Leningrad, Institute of Precambrian Geology and Geochronology, 106 p.

Tyler, S.A., and Barghoorn, E.S., 1954, Occurrence of structurally preserved plants in Pre-Cambrian rocks of the Canadian Shield: Science, v. 119 , p. $606-608$.

Vidal, Gonzalo, 1976, Late Precambrian microfossils from the Visingsö Beds in southern Sweden: Fossils and Strata, no. 9, 57 p.

1979, Acritarchs from the Upper Proterozoic and Lower Cambrian of East Greenland: Gr $\phi$ nlands Geologiske Unders $\phi$ gelse Bulletin 134, p. 1-40.

1981, Micropaleontology and biostratigraphy of the Upper Proterozoic and Lower Cambrian sequence in East Finnmark, northern Norway: Norges Geologiske Unders $\phi$ kelse Bulletin 59, p. 1-53.

Walcott, C.D., 1920, Middle Cambrian sponges: Smithsonian Miscellaneous Collections, v. 67, p. 261-364.

Young, G.M., 1982, The late Proterozoic Tindir Group, east-central Alaska: evolution of a continental margin: Geological Society of America Bulletin, v. 93, no. 8, p. 759-783.

Zhuravleva, I.T., and Korde, K.B., 1955, Nachodka gubki Chancelloria Walcott v. otlozenijack niznego Kembrija Sibiri [Discovery of the sponge Chancelloria Walcott in Lower Cambrian deposits of Siberia]: Doklady Akademiya Nauk SSSR, Moscow, v. 104, no. 3, p. 474-477.

Ziegler, P.A., 1959, Frühpaläozoische tillite im östlichen YukonTerritorium (Kanada) [Early Paleozoic tillite in eastern Yukon Territory, Canada]: Ecologae, Geologia Helvetia, v. 52, p. 735-741. 
APPENDIXES A-C 
APPENDIX A.-Locality descriptions

Eagle area:

63AGs253A. Black siliceous shale at approximately 1,400 feet elevation, north of Mission Creek in $\mathrm{SE}^{1 / 4} \mathrm{SE}^{1 / 4}$ sec. 16, T. $1 \mathrm{~S}$., R. $32 \mathrm{E}$; lat $64^{\circ} 49.4^{\prime} \mathrm{N}$., long $141^{\circ} 19^{\prime} \mathrm{W}$. Greenstone unit of Brabb and Churkin (1965). Collector, D.L. Giles, 1963.

A-1386. Fractured black siliceous shale at approximately $1,100 \mathrm{ft}$ elevation, north of Mission Creek in $\mathrm{SW}^{1 / 4} \mathrm{SE}^{1 / 4}$ sec. 16, T. $1 \mathrm{~S}$., R. 32 E.; lat $64^{\circ} 49.4^{\prime}$ N., long $141^{\circ} 19.3^{\prime}$ W. Greenstone unit of Brabb and Churkin (1965). Collector, D.B. Stone, 1974.

60ABa971A. Dark-gray siliceous shale exposed at low water on east bank of Yukon River in NE cor. sec. 29, T. 1 S., R. 33 E.; lat $64^{\circ} 48^{\prime} \mathrm{N}$., long $141^{\circ} 10141 \mathrm{~W}$. Quartzite and argillite unit of Brabb and Churkin (1965). Collector, E.E. Brabb, 1960.

Tatonduk area:

A-21. Archeocyathid limestone, from 1-m-diameter boulder about $75 \mathrm{ft}$ above river level on north bank of Tatonduk River. Original stratigraphic position estimated to be approximately midway between prominent basal bed of the Hillard Limestone and top of the Funnel Creek Limestone. $\mathrm{SE}^{1 / 4} \mathrm{sec}$. 3, T. 2 N., R. 32 E.; lat $65^{\circ} 1.5^{\prime} \mathrm{N}$., long $141^{\circ} 12^{\prime} \mathrm{W}$. Adams Argillite. Collector, C.W. Allison, 1971.

A-922. Gray limestone in saddle between two small peaks of $3,500+$ ft elevation, $\mathrm{SW}^{1 / 4} \mathrm{NW}^{1 / 4} \mathrm{sec}$. 32 , T. 2 N., R. $33 \mathrm{E}$.; lat $64^{\circ} 57.5^{\prime}$ N., long $141^{\circ} 5.2^{\prime}$ W. Adams Argillite. Collector, Dirk Bodnar, 1977.

A-1387. Black cherty shale in maroon shales exposed in bluff on north bank of Tatonduk River in NE1/4 NE $1 / 4$ sec. 12 , T. 2 N., R. $33 \mathrm{E}$.; lat $65^{\circ} 1.3^{\prime} \mathrm{N}$., long $141^{\circ} 7^{\prime} \mathrm{W}$. Basalt and red beds unit of the Tindir Group. Collector, C.W. Allison, 1973.

A-1388. Dark-red chert exposed near river level on Tatonduk River approximately $0.2 \mathrm{~km}$ west of A-1387. Lat $65^{\circ} 1.3^{\prime} \mathrm{N}$., long $141^{\circ} 7.2^{\prime} \mathrm{W}$. Basalt and red beds unit. Collector, C.W. Allison, 1973.

K101-74. Dark-gray cherty limestone, Pass Creek north of Tatonduk River. Sec. 35, T. 3 N., R. 32 E. Limestone unit of the Tindir Group. Collector, G.L. Kline, 1974.

CA 637. Buff-weathering dark-gray limestone with black chert nodules, $7 \mathrm{~m}$ below the Funnel Creek Limestone. East of upper Tindir Creek, approximately $10 \mathrm{~km}$ east of United States-Canada boundary and $30 \mathrm{~km}$ north of Cathedral Creek. Limestone unit of the Tindir Group. Collector, N.A. Crozer, 1979.

Nation area (vicinity of Yukon River):

A-99. Black shale, interbedded with dolomite, west bank of Yukon River approximately $40 \mathrm{~m}$ north of north end of greenstone. $\mathrm{SE}^{1 / 4} \mathrm{SW}^{1 / 4}$ sec. 5 , T. 5 N., R. 28 E. Limestone unit(?) of the Tindir(?) Group. Collector, C.W. Allison, 1971.

A-1023. Orange-weathering greenish-gray argillite, east bank of Nation River in west-center sec. 30, T. 5 N., R. 30 E., Adams Argillite. Collector, B.I. Clardy, 1975.

A-1389. Black shale, interbedded with dark-gray dolomite, west bank of Yukon River approximately $135 \mathrm{~m}$ north of mouth of Schley Creek, center sec. 36, T. 5 N., R. 28 E.; lat $65^{\circ} 13^{\prime}$ N., long $141^{\circ} 53^{\prime} \mathrm{W}$. Dolomite and shale unit of the Tindir Group. Collector, C.W. Allison, 1971.
Nation area (vicinity of Yukon River)-Continued

A-1391. Black shale, interbedded with dark-gray dolomite, west bank of Yukon River approximately $16 \mathrm{~m}$ south of south end of greenstone on line between secs. 5 and 8, T. 5 N., R. 28 E. Basalt and red beds unit(?) or the Tindir(?) Group. Collector, C.W. Allison, 1971.

Nation area (Washington Creek):

$62 \mathrm{ABa} 2541$. Finely laminated gray cherty shale exposed on east side of creek at bend in center sec. 25 , T. 5 N., R. 26 E.; lat $65^{\circ} 13.9^{\prime}$ N., long $142^{\circ} 17.5^{\prime}$ W. Basalt and red beds unit(?) of the Tindir(?) Group. Collector, E.E. Brabb, 1962.

$63 \mathrm{ACn} 2452$. Laminated gray cherty shale east of creek at approximately $1,000 \mathrm{ft}$ elevation, $0.4 \mathrm{~km}$ north of center sec. 25 , T. $5 \mathrm{~N}$., R. 26 E.; lat $65^{\circ} 14.2^{\prime}$ N., long $142^{\circ} 17.7^{\prime}$ W. Collector, M. Churkin, Jr., 1963.

UCSB 544. Black siliceous shale and chert interbedded with, and fragmental in, microbreccia [of] probable pyroclastic aqueous deposition. West bank of Washington Creek in $\mathrm{SE}^{1 / 4} \mathrm{NW}^{1 / 4}$ sec. 25 , T. 5 N., R. 26 E. Collector, P.E. Cloud, 1975.

A-1392. Black cherty shale in blocky-fracturing, banded black and gray beds near water line at north end of outcrops on west bank of creek at approximately $900 \mathrm{ft}$ elevation, $\mathrm{SE}^{1 / 4} \mathrm{NW}^{1 / 4} \mathrm{sec} .25$, T. 5 N., R. 26 E.; lat $65^{\circ} 14^{\prime}$ N., long $142^{\circ} 17.8^{\prime}$ W. Basalt and red beds unit(?). Collector, D.B. Stone, 1974.

A-1393. Black cherty shale, approximately same horizon as A-1392. Collector, C.W. Allison, 1976.

A-1394. Black cherty shale approximately $1.8 \mathrm{~m}$ stratigraphically above A-1392 at same location. Collector, D.B. Stone, 1974.

A-1395. Silty black shale, one of several random samples collected over 1-m-thick interval below prominent gray tuff bed at outcrop described for A-1392. Collector, M.W. Payne, 1975.

A-1396. Black cherty shale, same location as A-1395. Collector, M.W. Payne, 1975.

A-1397. Dark-gray cherty shale, same location as A-1395. Collector, M.W. Payne, 1975.

A-1398. Gray cherty shale, same location as A-1395. Collector, M.W. Payne, 1975.

A-1399. Gray cherty shale, same location as A-1395. Collector, M.W. Payne, 1975.

A-1400. Black cherty shale near south end of outcrop described for A-1392. Collector, M.W. Payne, 1975.

A-1401. Fractured black and gray cherty shales exposed on west bank of creek about $15 \mathrm{~m}$ upstream from south end of outcrop described for A-1392. Collector, C.W. Allison, 1976.

A-1402. Black shale in grayish-brown silty shales on west bank of creek about $150 \mathrm{~m}$ south of A-1401. Collector, C.W. Allison, 1976.

A-1403. Gray cherty shale from slumped beds on east bank of creek; approximately $250 \mathrm{~m}$ south of $62 \mathrm{ABa} 2541$. Collector, C.W. Allison, 1976.

A-1404. Gray cherty shale, same map location but not necessarily same horizon as 62ABa2541. Collector, D.B. Stone, 1974.

A-1405. Finely laminated, friable gray and black cherty shale, same map location but not necessarily same horizon as $62 \mathrm{ABa} 2541$. Collector, D.B. Stone, 1974.

A-1406. Black cherty shale on west bank of creek at bend in center sec. 25 , T. 5 N., R. 26 E.; lat $65^{\circ} 13.8^{\prime}$ N., long $142^{\circ} 17.8^{\prime} \mathrm{W}$. Collector, M.W. Payne, 1975.

A-1407. Fractured, finely laminated dark-gray chert on east bank of creek in sharp bend in $\mathrm{NE}^{1 / 4} \mathrm{SW}^{1 / 4}$ sec. 25 , T. 5 N., R. 26 E.; lat $65^{\circ} 13.75^{\prime}$ N., long $142^{\circ} 17.8^{\prime}$ W. Collector, M.W. Payne, 1975. 
Woodchopper area (Takoma Bluff):

A-1408. Brittle, brown-weathering, dark-gray siliceous shale, near base of bluff approximately $100 \mathrm{~m}$ south of south end of major blocky talus cone that reaches Yukon River at Takoma Bluff, in NW1/4SW1/4 sec. 32 , T. 8 N., R. 20 E.; lat $65^{\circ} 28.6^{\prime}$ N., long $143^{\circ} 41^{\prime}$ W. Undivided sedimentary rocks unit of Brabb and Churkin (1969). Collector, C.W. Allison, 1973.

A-1409. Black siliceous shale in high-dipping cherty beds about $22 \mathrm{~m}$ north of thin conglomerate lens near north end of major blocky talus cone described for A-1408. NW1/4 NW1/4 sec. 32 , T. 8 N., R. $20 \mathrm{E}$.; lat $65^{\circ} 28.7^{\prime} \mathrm{N}$., long $143^{\circ} 41^{\prime} \mathrm{W}$. Undivided sedimentary rocks unit of Brabb and Churkin (1969). Collector, C.W. Allison, 1976.

A-1627. Black limestone about $300 \mathrm{~m}$ north of A-1409. Collector, S.M. Awramik, 1979.
Woodchopper area (southeast exposures):

62ABa2132. Orange-weathering, finely laminated medium-gray cherty shale, west bank of small unnamed tributary to Eureka Creek, $\mathrm{NE}^{1 / 4} \mathrm{NW}^{1 / 4}$ sec. 12 , T. 7 N., R. 21 E.; lat $65^{\circ} 27.2^{\prime}$ N., long $143^{\circ} 19.5^{\prime} \mathrm{W}$. Undivided sedimentary rocks unit of Brabb and Churkin (1969). Collector, E.E. Brabb, 1962.

63ABa4176. Orange-weathering, dark-gray argillite, west bank of Edwards Creek, center sec. 14 , T. 7 N., R. 22 E.; lat $65^{\circ} 26^{\prime}$ N., long $143^{\circ} 9.3^{\prime} \mathrm{W}$. Undivided sedimentary rocks unit of Brabb and Churkin (1969). Collector, E.E. Brabb, 1963.

EU 3. Dark-gray argillite, reported by collector to be from same outcrop as 62ABa2132. Collector, P.L. Brown, 1981. 
[Thin sections with A-, CA, K, and EU numbers deposited at University of Alaska Museum; thin section with UCSB number at Cloud Biogeology Laboratory, University of California, Santa Barbara; al1 other thin sections at U.S. National Museum]

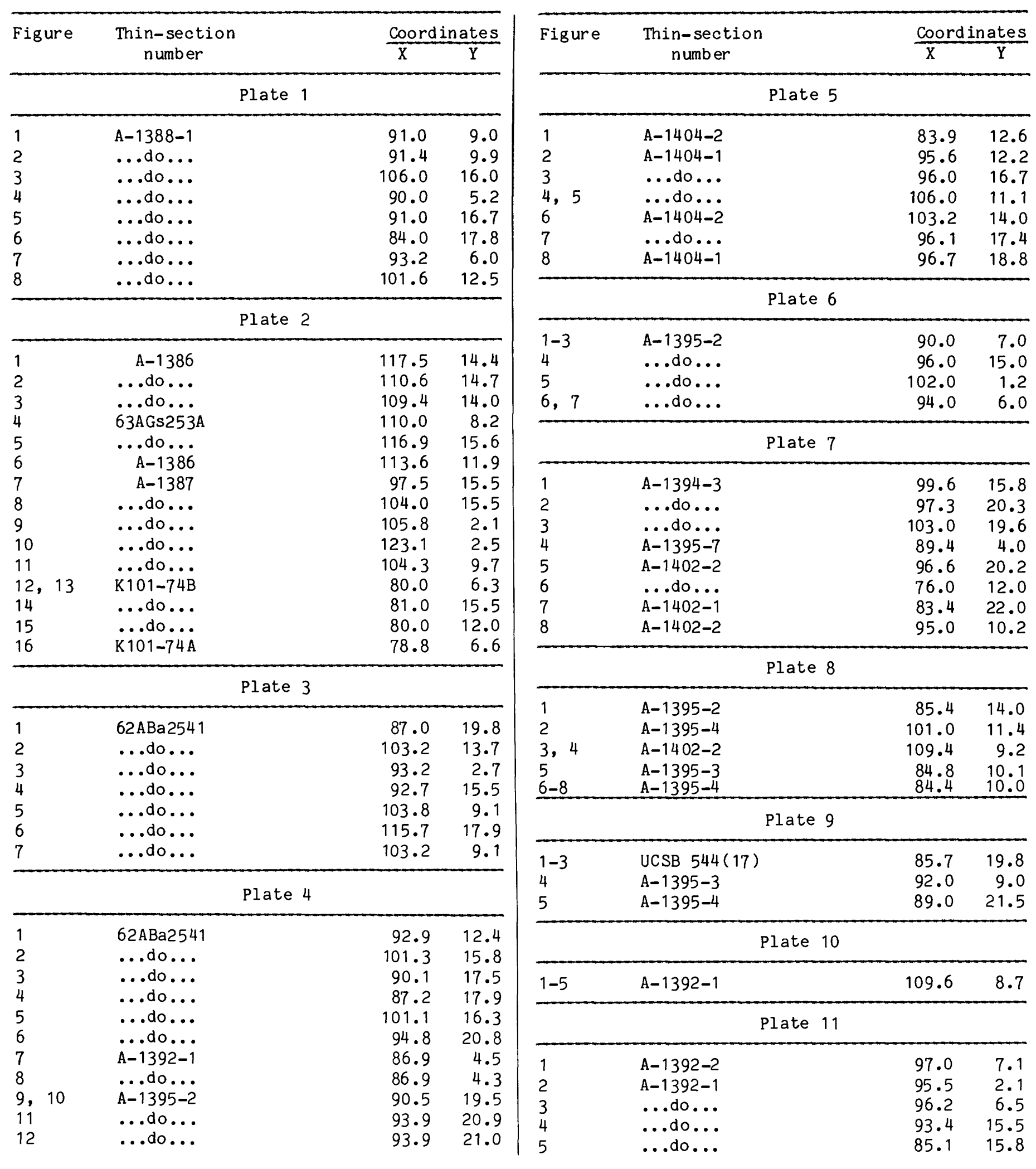


APPENDIX B.-Thin-section coordinates for illustrated specimens-Continued

\begin{tabular}{|c|c|c|c|}
\hline \multirow[t]{2}{*}{ Figure } & \multirow{2}{*}{$\begin{array}{c}\text { Thin-section } \\
\text { number }\end{array}$} & \multicolumn{2}{|c|}{ Coord inates } \\
\hline & & $\mathrm{X}$ & $\mathrm{Y}$ \\
\hline \multicolumn{4}{|c|}{ Plate 11--Continued } \\
\hline $\begin{array}{l}6 \\
7 \\
8\end{array}$ & $\begin{array}{l}\ldots \text { do... } \\
\ldots \text { do... } \\
\ldots \text { do... }\end{array}$ & $\begin{array}{l}94.8 \\
95.8 \\
85.7\end{array}$ & $\begin{array}{r}15.0 \\
3.4 \\
11.6\end{array}$ \\
\hline \multicolumn{4}{|c|}{ Plate 12} \\
\hline $\begin{array}{l}1 \\
2 \\
3 \\
4 \\
5,6 \\
7 \\
8,9 \\
10\end{array}$ & $\begin{array}{c}A-1408-2 \\
\ldots \text { do } . . . \\
\ldots \text { do } \ldots \\
A-1408-1 \\
A-1408-3 \\
A-1408-2 \\
A-1408-1 \\
A-1408-2\end{array}$ & $\begin{array}{l}107.9 \\
107.8 \\
113.0 \\
115.0 \\
109.0 \\
103.0 \\
115.2 \\
120.8\end{array}$ & $\begin{array}{r}15.3 \\
15.8 \\
10.0 \\
2.5 \\
3.1 \\
8.0 \\
8.1 \\
13.0\end{array}$ \\
\hline \multicolumn{4}{|c|}{ Plate 13} \\
\hline $\begin{array}{l}1 \\
2 \\
3 \\
4 \\
5 \\
6 \\
7 \\
8 \\
9 \\
10\end{array}$ & $\begin{array}{l}A-1408-1 \\
\ldots \text { do } \ldots \\
A-1408-3 \\
\ldots \text { do } \ldots \\
A-1408-1 \\
A-1408-2 \\
\ldots \text { do } \ldots \\
\ldots \text { do... } \\
\ldots \text { do... } \\
\ldots \text { do ... }\end{array}$ & $\begin{array}{r}114.0 \\
106.9 \\
112.0 \\
99.0 \\
112.5 \\
114.6 \\
116.4 \\
120.1 \\
116.8 \\
116.9\end{array}$ & $\begin{array}{r}6.0 \\
12.5 \\
12.2 \\
9.8 \\
5.0 \\
12.9 \\
18.7 \\
16.9 \\
11.9 \\
11.7\end{array}$ \\
\hline \multicolumn{4}{|c|}{ Plate 14} \\
\hline $1-6$ & $A-1408$ & SEM & \\
\hline \multicolumn{4}{|c|}{ Plate 15} \\
\hline $\begin{array}{l}1,2 \\
3\end{array}$ & $\begin{array}{l}A-1409-1 \\
\ldots \text { do... }\end{array}$ & $\begin{array}{l}110.5 \\
106.4\end{array}$ & $\begin{array}{r}10.1 \\
6.5\end{array}$ \\
\hline
\end{tabular}

\begin{tabular}{|c|c|c|c|}
\hline \multirow[t]{2}{*}{ Figure } & \multirow{2}{*}{$\begin{array}{c}\text { Thin-section } \\
\text { number }\end{array}$} & \multicolumn{2}{|c|}{ Coord inates } \\
\hline & & $\mathrm{X}$ & $\mathrm{Y}$ \\
\hline \multicolumn{4}{|c|}{ Plate 15--Continued } \\
\hline 4 & ...do... & 98.9 & 6.8 \\
\hline 5,6 & ...do... & 109.4 & 6.1 \\
\hline 7,8 & $\ldots$..... & 109.5 & 5.5 \\
\hline \multicolumn{4}{|c|}{ Plate 16} \\
\hline 1 & $A-1409-1$ & 106.0 & 8.8 \\
\hline 2 & $A-1409-3$ & 83.0 & 18.2 \\
\hline 3 & ...do... & 82.3 & 20.9 \\
\hline 4 & ...do... & 106.0 & 20.5 \\
\hline 5 & $A-1409-1$ & 108.8 & 16.5 \\
\hline 6 & ...do... & 79.4 & 21.4 \\
\hline 7 & $A-1409-3$ & 83.2 & $18 \cdot 5$ \\
\hline 8 & $A-1409-2$ & 94.9 & $12 \cdot 5$ \\
\hline 9 & $A-1409-3$ & 98.4 & 13.2 \\
\hline 10 & $\ldots$ do... & 99.8 & 15.2 \\
\hline 11 & ...do... & 99.8 & 12.0 \\
\hline 12 & ...do... & 98.2 & 15.8 \\
\hline \multicolumn{4}{|c|}{ Plate 17} \\
\hline 1 & $62 \mathrm{ABa} 2132-1$ & 82.8 & 7.6 \\
\hline 2,3 & $62 \mathrm{ABa} 2132-2$ & 83.0 & 17.6 \\
\hline 4 & ...do... & 83.3 & $17 \cdot 5$ \\
\hline 5 & $62 \mathrm{ABa} 2132-1$ & 100.1 & 14.3 \\
\hline 6 & $62 \mathrm{ABa} 2132-3$ & 114.8 & 19.0 \\
\hline 7 & ...do... & 112.1 & 20.1 \\
\hline 8 & ...do... & 106.0 & 9.5 \\
\hline 9 & ...do... & 108.4 & 20.0 \\
\hline \multicolumn{4}{|c|}{ Plate 18} \\
\hline 4,5 & EU 3 & 112.8 & 14.0 \\
\hline
\end{tabular}




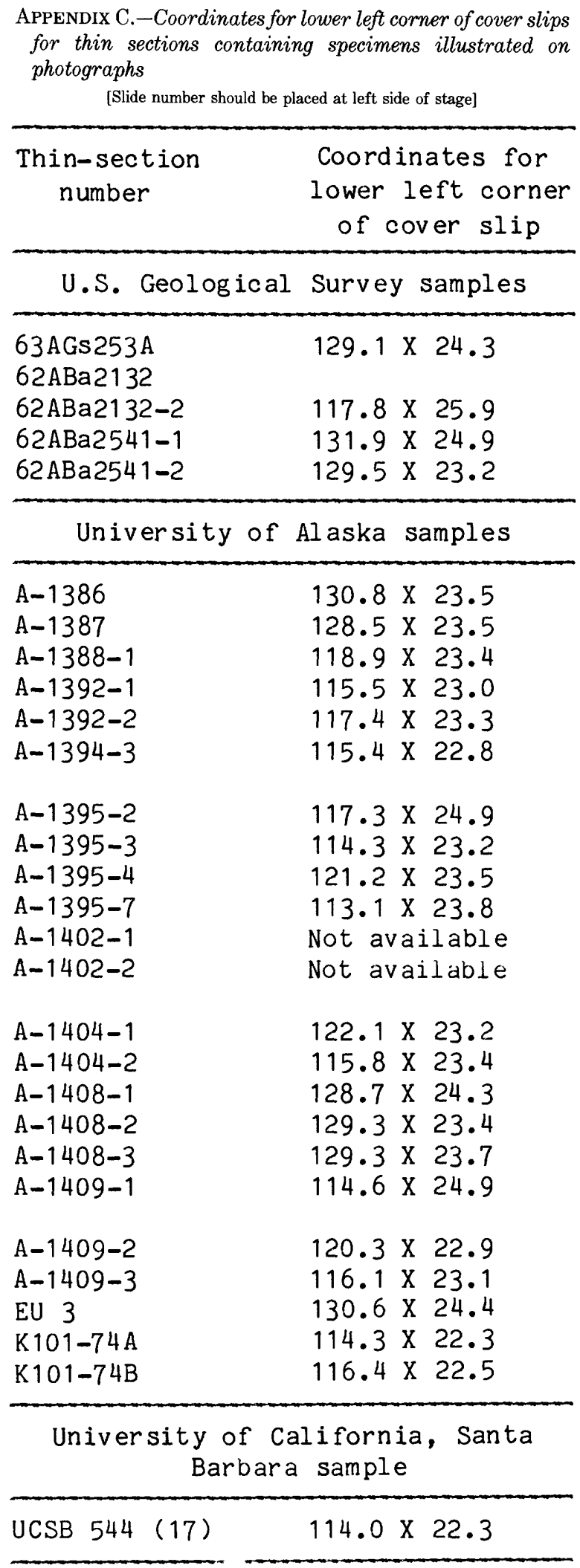




\section{INDEX}

[Italic page numbers indicate major references]

Abstract, 1

Acanthomorphitae, 23

Acknowledgments, 3

Acritarcha, 19, 23

Acanthomorph Type A, 10, 23; pl. 17

Acanthomorph Type B, 10, 24; pl. 17

Netromorphitae, 25

Adams Argillite, 7, 8, 12, 36-38; pl 18

Aldanella, 37

Algae, 7, 10, 25, 27, 30, 31

Allison, C.W., cited, 3, 4, 6, 7, 18, 40

Allomyces, 30, 31, 34

Allonnia, 34

Anabaenidium johnsoni, 22

Anthozoa, 36

antiqua, Archiasterella, 33

Oldhamia, 38

Aphanocapsa, 23

Appendix A-Locality descriptions, 44

Appendix B-Thin-section coordinates, 46

Appendix C-Cover-slip coordinates for thin sections, 48

Archiasterella, 34 antiqua, 33

Argillite unit. See Quartzite and argillite unit

Arthropoda, 8, 10, 19, 37

Type A, 37 , pl. 9

Type B, 37 , pl. 9

Type C, $37, \mathrm{pl} .18$

Ascomycetae, 31

Australia, 14, 22

\section{B}

Bacteria, 4, 7, 9-11, 13, 14, 17

Baicalia, 4

Barghoorn, E.S., cited, 14

Basalt and red beds unit. See Tindir Group

Basaltic unit, Woodchopper area, 9, 12

Bavlinella, 8, 13, 15, 17, 23

sp., 4, 17; pl. 2

Blastocladia, 30,31

Blastocladiales, 30

Brabb, E.E., cited, 2-4, 7-9

Brabbinthes, 28, 38, 40

churkini, $8,33,37$; pl. 10

\section{C}

Cairnes, D.D., cited, 2

Cambrian, 2, 4, 5, 7-10, 19, 24, 25, 34, 36-39

Canada, 3, 14, 19, 37, 39

Caulococcus, 14; pl. 1

Cephalophytarion, 22

Chaemosiphonales, 19

Chancelloria, 34

multirayed form, 35

sp., 8, 34; pl. 6

?Chancelloria, 36

Type A, 8, 36 ; pl. 7

Type B, 8,36 ; pl. 7

Chancelloriidae, $7,10,13,33,34,36,38,40$

Chroococcales, 19

Churkin, M., Jr., cited, 9

churkini, Brabbinthes, $8,33,37$; pl. 10

Cloud Laboratory, University of California at Santa Barbara, 13

Cloud, P.E., cited, 38

Coelenterata, 36

Coeloscleritophora, 34
Collection areas, 3,44

Contents, III

Correlation, 10, 12

Cover-slip coordinates for thin sections-Appendix C, 48

Crimes, T.P., cited, 38

Cyanobacteria, $7,13,15,27,30-32$; pls. 3, 4, 13-16

?Cyanobacteria, 21

Coccoid Type A, 8, 20, 22; pl. 4

Coccoid Type B, 4, 22, 23, 25; pl. 2

Filament Type A, 8, 21; pl. 4

Filament Type B, 8, 21; pl. 4

Filament Type C, 4, 22; pl. 2

Cylindromyces, 28, 30, 31

septatus, 10, 17, 28, 29; pl. 12

D, E

dentifera, Deunffía, 25

Deunffia dentifera, 25

Dolomite and shale unit. See Tindir Group

Dolomitic sandstone and shale unit. See Tindir Group

Dolomitic unit, Woodchopper area, 9, 12

Eagle area, 3, 11, 13, 17-19, 22, 23, 25, 26, 31; pl. 2 Greenstone unit, $3,4,15,18,19,22,23,25$; pl. 2 Limestone unit, 3

Quartzite and argillite unit, 3-4, 15, 17, 18

Edwards Creek, 10, 38; pl. 18

Eiffelia, 34

Eoastrion, 14

?Eoastrion sp., 7, 14; pl. 1

Evenchick, C.A., cited, 19

F
Flatworm, 37
Fluid inclusions, 17
Fossil localities, 3, 44
fuliginosa(?), Pleurocapsa, 19
Fungi, 7, 10, 13, 17, 27, 28; pl. 12, 13
Fungi Sporae Dispersae, 30
?Fungi, 7, 31; pls. 13, 14
Type A, 7, 31; pl. 2
Type B, 8, 32; pl. 5
?Fungi Imperfecti, 30
Oval Spore Type A, 10, 25, 30; pls. 13, 14
Oval Spore Type B, 10, 30, 31; pls. 13, 14

Funnel Creek Limestone, 7, 12

G, H

Glenn Shale, 10

Green, L.H., cited, 19

Greenstone unit, Eagle area, 3, 4, 15, 18, 19, 22, 23, 25; pl. 2

Grit unit, Canada, 3

Handfield, R.C., cited, 36

Hector Formation, 19

Hillard Limestone, 7, 8

Hyalospongia, 33

\section{I, J, K}

Incertae Sedis, 33,38

Type A, 8, 39; pl. 9

Type B, 8, 39 ; pl. 4

Type C, $8,33,37,39 ; \mathrm{pl} .11$

See also Metazoa; ?Oldhamia; Porifera; Protista Interpretation, 13

Introduction, 1

irregularia, Paleonostocalia, 8, 19, 20, 22; pls. 3, 4 johnsoni, Anabaenidium, 22

Jones Ridge Limestone, 8, 12

Kalliokoski, J., cited, 18

Kline, G.L., cited, 14

kordeae, Tabulaconus, 36 ; pl.18

\section{L, M}

Laboratory procedures, 18

Limestone unit, Eagle area, 3

Limestone unit. See Tindir Group

Locality descriptions-Appendix A, 44

Loeblich, A.R., cited, 24

Mertie, J.B., Jr., cited, 2

Metallogenium, 1, 14

Metazoa, 7, 8, 10, 28

Incertae Sedis, 37

Monocellae, 30

Moorman, M.A., cited, 3, 7, 9, 15, 18, 19

Multirayed form. See Chancelloria; ?Porifera

N, O

Nation area, 1-4, 7, 10, 11, 13, 15, 17-19, 23; pls. 3-11, 18

Stratigraphic column,

Tindir Group, 7, 9, 10, 12, 18

See also Washington Creek

Nostocaceae, 19

Nostocales, 19

Obruchevella sp., 7; pl.

Oldhamia, 10, 38; pl. 18

antiqua, 38

radiata, 38

?Oldhamia, 19, 38; pl. 18

sp., 10,38 ; pl. 18

Ordovician, 4, 7, 19, 24, 34

Oval Spore Type A, ?Fungi Imperfecti, 10, 25, 30; pls.

Oval Spore Type B, ?Fungi Imperfecti, 10, 30, 31; pls. 13,14

$\mathbf{P}$

Paleonostocalia, 19, 23

irregularia, $8,19,20,22 ;$ pls. 3,4

Paleontology, 10

Paradise Creek Formation, 14

Payne, M.W., cited, 21

Pelagiella, 37

Pennsylvanian, 34

Perfil'ev, B.V., cited, 14

Phycomycetae, 28, 31

Planolites, 9, 10, 19

Pleurocapsa fuliginosa(?), 19

Pleurocapsales, 15,19

Porifera, 33, 34

Incertae Sedis, 8,$33 ; \mathrm{pl} .7$

?Porifera, 33, 38

Unnamed multirayed form, $8,33,38,40 ; \mathrm{pl} .11$

Proterozoic, 1-5, 7-10, 12, 19, 24, 25, 38, 39

Protista, 7, 10; pls. 11, 12, 16, 17

Incertae Sedis, 24

Type A, 10, 24, 25; pl. 17

Type B, 10, 24, 25; pl. 17

Type C, 4, 22, 23, 25; pl. 2

Type D, 10, 25, 26; pl, 16

Type E, 10, 26; pl. 12

Type F, 10, 26, 27, 34, 40; pl. 16

Type G, 8, 15, 28, 37, 40; pl. 11

Pyrite replacement, 18 


\section{Q, R}

Quartzite and argillite unit, Eagle area, 3-4, 15, 17, 18 radiata, Oldhamia, 38

Radiolaria, 26

References cited, 40

Sample localities, 4

Sample repositories, 13

Sampling procedures, 11

Saprolegniales, 28, 30

Scanning electron microscopy (SEM), 13, 30; pl. 14

Scytonemataceae, 21

Sdzuy, K., cited, 35,36

Sedimentary rocks unit, undivided, Woodchopper area $9,10,12,15,17$

septatus, Cylindromyces, 10, 17, 28, 29; pl. 12

Shale unit. See Tindir Group

Sphaerocongregus, 4, 13, 15, 18, 19, 23, 27, 29, 31; pl. 16

variabilis, $9,10,15,18,19,26,27,30$; pls. $12-16$

?Sphaerocongregus sp., 4, 17

Sponges, 34

St. Piran Quartzite, 19

Stratigraphic column, Nation area, 9

Tindir Group, 6, 9, 10, 12

Stratigraphy, general, 3

Stromatolitic limestone. See Tindir Group

Systematic paleontology, 14
Tabulaconus kordeae, 36 ; pl. 18

Takoma Bluff, Woodchopper area, 1, 3, 9-11, 13, 15 , $17-19,21,23-28,30,31,34,38,40$; pls. $12-16$

Tatonduk area, 1-4, 5, 14, 17, 31, 32, 37; pls. 1, 2, 18 Adams Argillite, 12

Jones Ridge Limestone, 12

Tindir Group, 4, 12, 13

Thin-section coordinates-Appendix B, 46

Timoféev, B.V., cited, 24

Tindir Group, 1-3, 4, 5-7, 9-13, 15, 17, 18, 32 basalt and red beds unit, 4, 6-8, 10,12,14, 18 , 21-23, 28, 32-34, 36-40; pls. 1-11

dolomite and shale unit, $4,6,8,9,12,15,18,19$ dolomite, shale, and quartzite unit, 4

dolomitic sandstone and shale unit, 4, 6, 12, 18

limestone unit, 4, 6-8, 12,15,18, 19; pl. 2

lower part, $1,7,9,12,18,19$

Nation area, $7,9,10,12,18$

shale unit, $4,6,12$

stratigraphic column, $6,9,10,12$

stromatolitic limestone, 4, 6, 12

Tatonduk area, $4,12,13$

upper part, 1, 3, 4, 7

See also Washington Creek, Nation area

Tommotian age, 24

Toquimiella, 34

Trace fossils, 3,4
Triassic, 10

Trilobites, 37

U, V

U.S. National Museum, 13

University of Alaska Museum, 13

Unnamed Form A, 25

Unnamed multirayed form, ?Porifera, 8, 33, 38, 40; pl. 11

variabilis, Sphaerocongregus, 9, 10, 15, 18, 19, 26, 27 . 30 ; pls. $12-16$

Vidal, G., cited, 18

Volvocales, 25, 28

$$
\text { W, Y }
$$

Washington Creek, Nation area, 3, 7, 8, 10, 11, 13, $20-23,28,33-40$; pls. 3-11

Windermere Group, 1, 19

Woodchopper area, 2, 9, 10-12, 23-26, 37, 39; pls. $12-18$

basaltic unit, 9,12

dolomitic unit, 9,12

stromatolitic limestone unit, 9, 12

undivided sedimentary rocks unit, $9,10,12,15,17$, $24-28,30,31,37,39$; pl. 18

Worm traces, 4, 19, 38

Young, G.M., cited, 3, 4, 6

Yukon Territory, 3 


\section{PLATES 1-18}

[Contact photographs of the plates in this report are available, at cost, from U.S. Geological Survey Library, Federal Center, Denver, Colorado 80225] 


\section{PLATE 1}

Bacteria from basalt and red beds unit of the Tindir Group, Tatonduk area

FIgUREs 1-8. ?Eoastrion from red chert, Tatonduk River section. UAK A-1388.

1, 2. Filaments and small colonies in pale chert clast. Specimens in these clasts do not exhibit the overgrowth of iron and (or) manganese minerals commonly present on specimens in surrounding matrix. Bar is $100 \mu \mathrm{m}$ long in figure 1; bar is $50 \mu \mathrm{m}$ long in figure 2 .

3 , 4. Round patches with faint radial arrangement. These are similar in size and appearance to zoogleal branched colonies of modern Caulococcus. Bars are $100 \mu \mathrm{m}$ long.

5-8. Trichospherical colonies in matrix. Linear arrangement of cocci forming individual filaments can be seen to upper right in figures 6 and 7 . Bars are $50 \mu \mathrm{m}$ long. 


\section{U.S. GEOLOGICAL SURVEY}
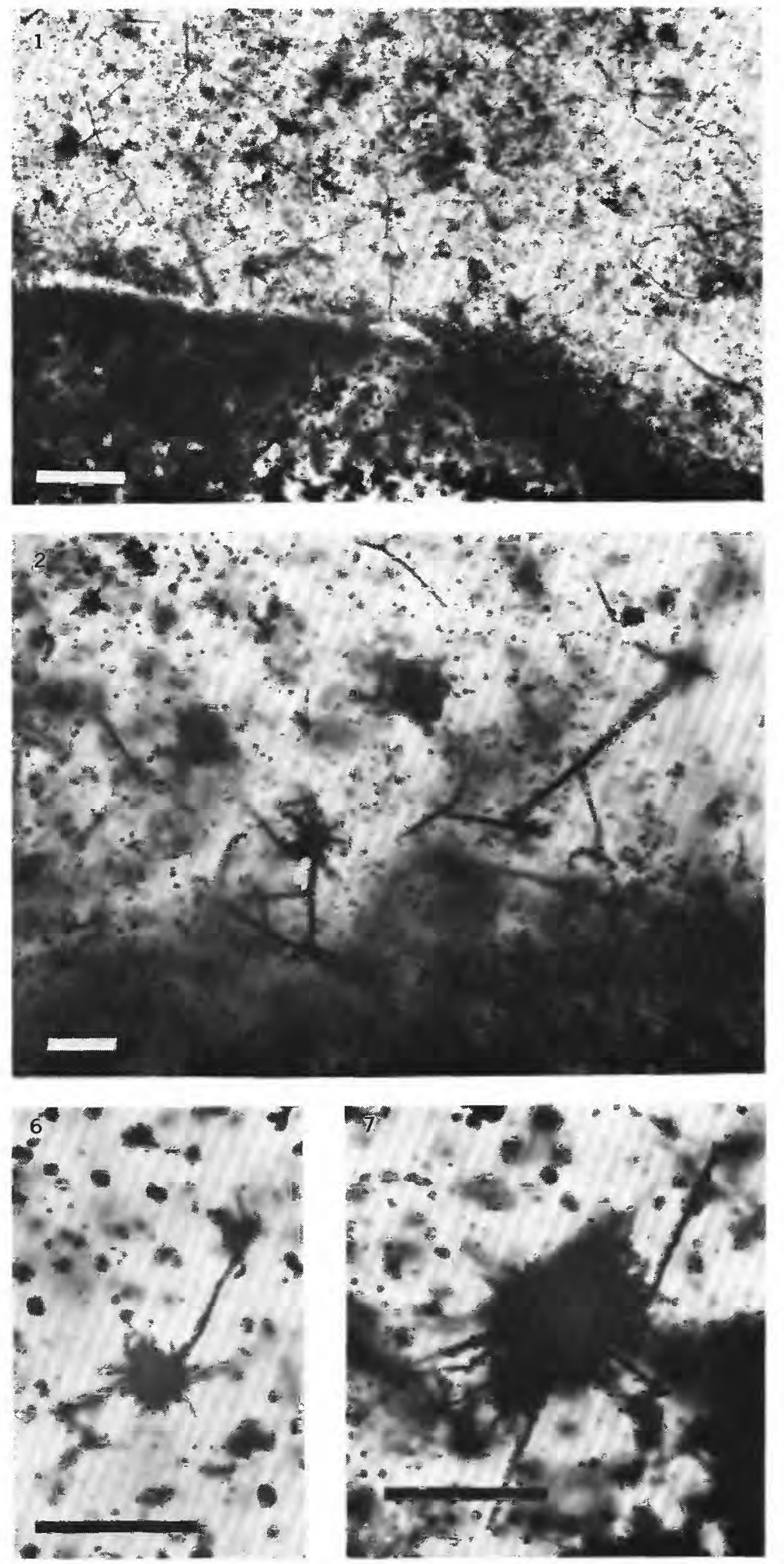

PROFESSIONAL PAPER 1449 PLATE 1
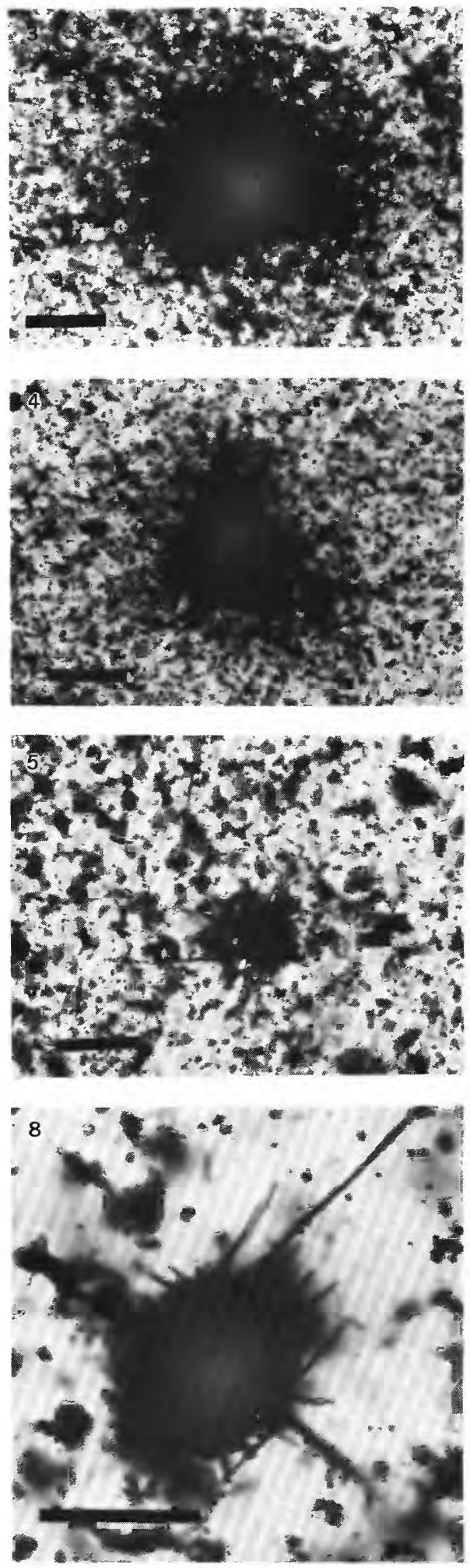

?EOASTRION 


\section{PLATE 2}

Microbial and fungal(?) fossils from Tatonduk and Eagle areas

Figures 1, 2. Protista Incertae Sedis Type C from greenstone unit of Brabb and Churkin (1965), Eagle area. UAK A-1386. Bars are $10 \mu \mathrm{m}$ long.

3. ?Cyanobacteria Coccoid Type B from greenstone unit, Eagle area. UAK A-1386. Bar is $25 \mu \mathrm{m}$ long.

4, 5. Bavlinella sp. from pale chert laminae in black shale of greenstone unit, Eagle area. USGS 63AGs253A. Unicells in figure 4 exhibit fine surface texture not visible on subunits of endosporangium in figure 5 . Bars are $10 \mu \mathrm{m}$ long.

6. ?Cyanobacteria Filament Type $\mathrm{C}$ from pale chert lamina in black shale of greenstone unit, Eagle area. UAK A-1386. Bar is $10 \mu \mathrm{m}$ long.

7, 8. ?Fungi Type A. Tubular fragments in black cherty layer in maroon shales, basalt and red beds unit of the Tindir Group, Tatonduk River. UAK A-1387. Bar is $100 \mu \mathrm{m}$ long in figure 7 ; bar is $50 \mu \mathrm{m}$ long in figure 8 .

9. Questionably biogenic structure, one of many rounded, frothy bodies in same horizon as fossils shown in figures $7,8,10$, and 11 . Bar is $10 \mu \mathrm{m}$ long.

10, 11. Pale spherical bodies that may be thin-walled cyanobacterial cells, from same horizon described above for ?Fungi Type A. Bars are $10 \mu \mathrm{m}$ long.

12-16. Filamentous fossils from chert nodule in dark-gray limestone of limestone unit of the Tindir Group, Tatonduk area. UAK K101-74.

12, 13. Mass of filamentous microbial sheaths in clast. Bar is $50 \mu \mathrm{m}$ long in figure 12; bar is $75 \mu \mathrm{m}$ long in figure 13.

14. Fragments of filamentous microbial sheaths. Bar is $50 \mu \mathrm{m}$ long.

15. Indeteriminate tubular fossils of varying diameters with distinct annular ribbed surface texture. Bar is $25 \mu \mathrm{m}$ long.

16. Obruchevella sp. Bar is $25 \mu \mathrm{m}$ long. 
U.S. GEOLOGICAL SURVEY
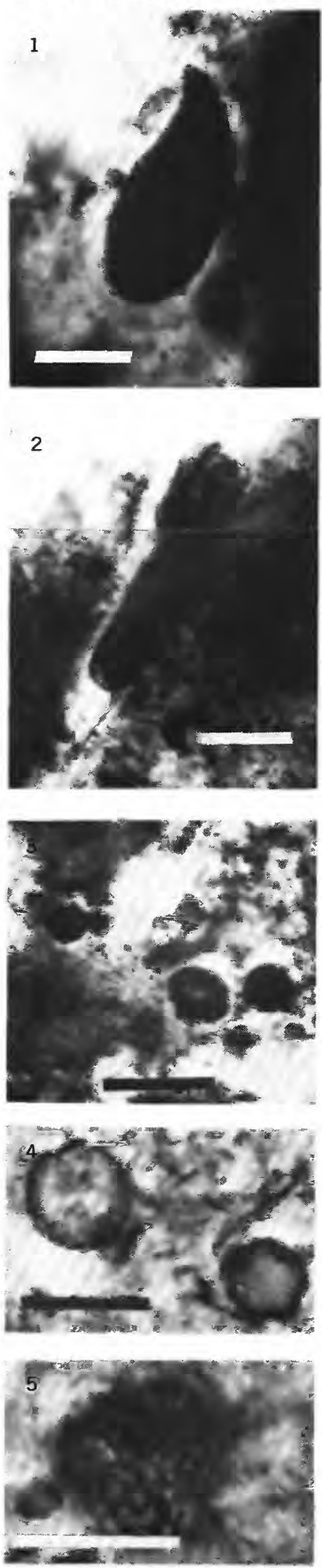

PROFESSIONAL PAPER 1449 PLATE 2
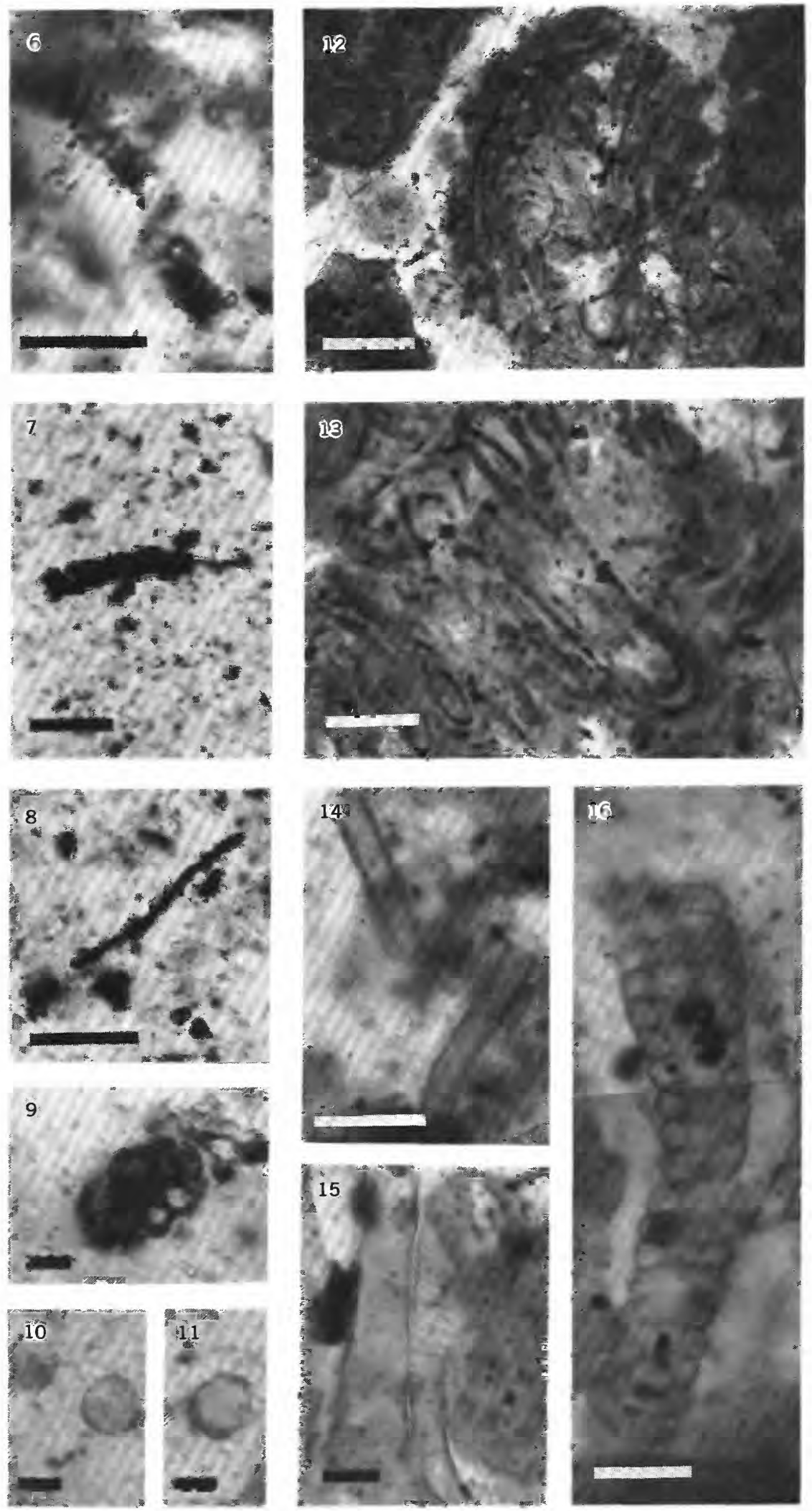

BAVLINELLA, OBRUCHEVELLA, OTHER CYANOBACTERIAL, PROTISTAN, AND FUNGAL(?) MICROFOSSILS 


\section{PLATE 3}

Filamentous Cyanobacteria from Washington Creek, Nation area

Figures 1-7. Paleonostocalia irregularia n. gen. and sp., from laminated gray cherty shale in basalt and red beds unit(?) of the Tindir(?) Group. USGS 62ABa2541.

1. Parts of filaments composed entirely of rod-shaped elements. Bar is $50 \mu \mathrm{m}$ long.

2. Filament apparently in process of releasing individual rod-shaped bodies. Small, thin, oblong structure between larger rods in right half of photo also appears to be biogenic. Bar is $25 \mu \mathrm{m}$ long.

3 , 4. Unusual associations of rod-shaped and spherical elements. Bars are $25 \mu \mathrm{m}$ long.

5-7. Specimens suggesting some form of branching. Bars are $25 \mu \mathrm{m}$ long. 
U.S. GEOLOGICAL SURVEY
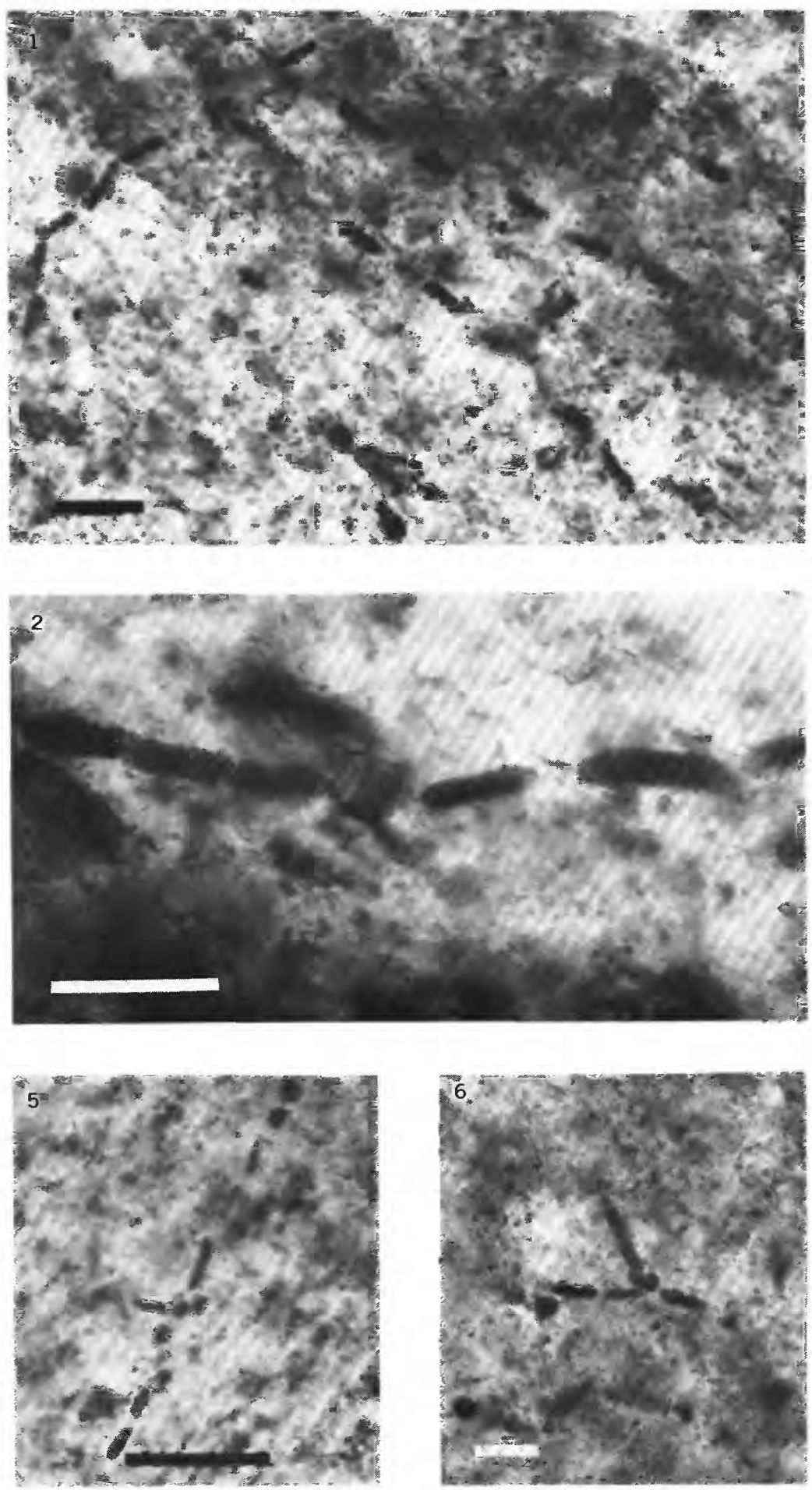

PROFESSIONAL PAPER 1449 PLATE 3
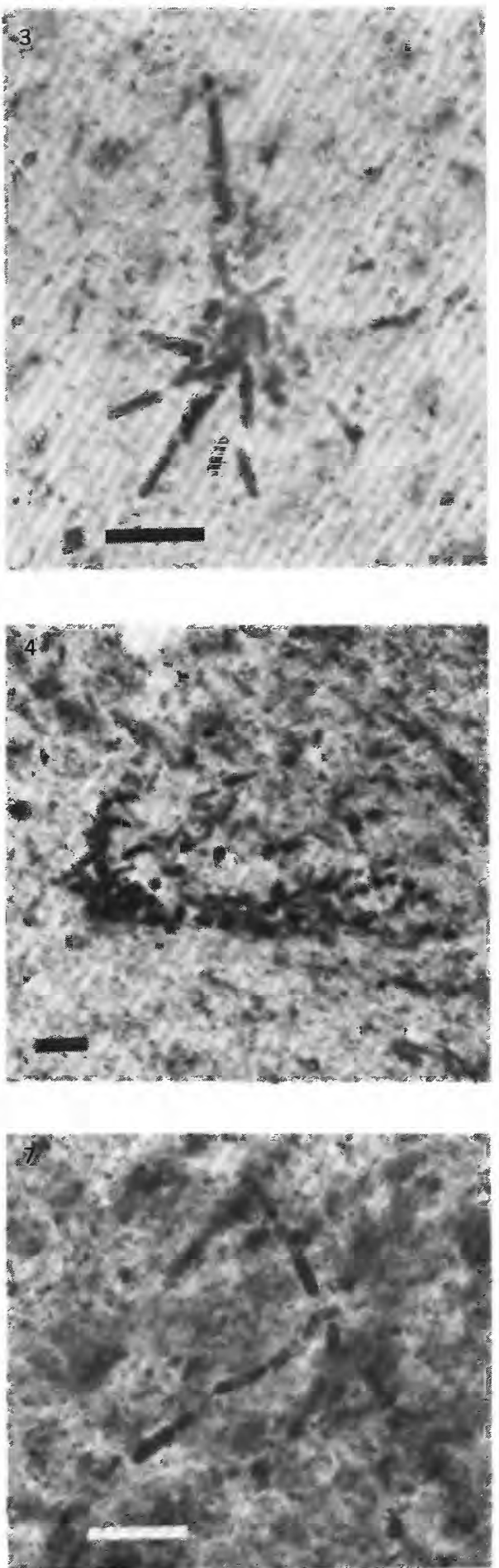


\section{PLATE 4}

Filamentous Cyanobacteria and coccoid and filamentous ?Cyanobacteria from basalt and red beds unit(?) of the Tindir(?) Group, Washington Creek, Nation area

Figures 1-4. Paleonostocalia irregularia n. gen. and sp. from laminated cherty shale. USGS $62 \mathrm{ABa} 2541$.

1, 2. Association of degraded sheath with spherical and rod-shaped elements. Note wide spacing of spheres in figure 1 . Bars are $10 \mu \mathrm{m}$ long.

3. Parts of filament containing both spherical and rod-shaped elements. Disarrangement of rods contrasts with more regular alignment of spheres of specimen shown in figure 4 . Bar is $50 \mu \mathrm{m}$ long.

4. Part of filament containing only spherical elements. Bar is $50 \mu \mathrm{m}$ long. 5, 6. ?Cyanobacteria Coccoid Type A, from same sample as filaments shown in figures 1-4.

5. Cells exhibit faint concentric banding, which is not interpreted to reflect original intracellular organization. Bar is $\mathbf{1 0} \mu \mathrm{m}$ long.

6. Mass containing cells exhibiting various stages of replacement with different iron-mineral phases. Bar is $25 \mu \mathrm{m}$ long.

7, 8. ?Cyanobacteria Filament Type B. UAK A-1392. Bar is $50 \mu \mathrm{m}$ long in figure 7; bar is $10 \mu \mathrm{m}$ long in figure 8 .

9-12. ?Cyanobacteria Filament Type A. UAK A-1395.

9,10 . Specimen with thick pale sheath having extremely fine, parallel membranes, $0.2 \mu \mathrm{m}$ thick, that appear as faintly beaded lines perpendicular to long axis of filament. Bar is $50 \mu \mathrm{m}$ long in figure 9 ; bar is $10 \mu \mathrm{m}$ long in figure 10.

11, 12. Fragmented specimen without sheath. Piece of shell of Incertae Sedis Type B is shown above filaments in figure 11. Bar is $50 \mu \mathrm{m}$ long in figure 11; bar is $10 \mu \mathrm{m}$ long in figure 12 . 
U.S. GEOLOGICAL SURVEY
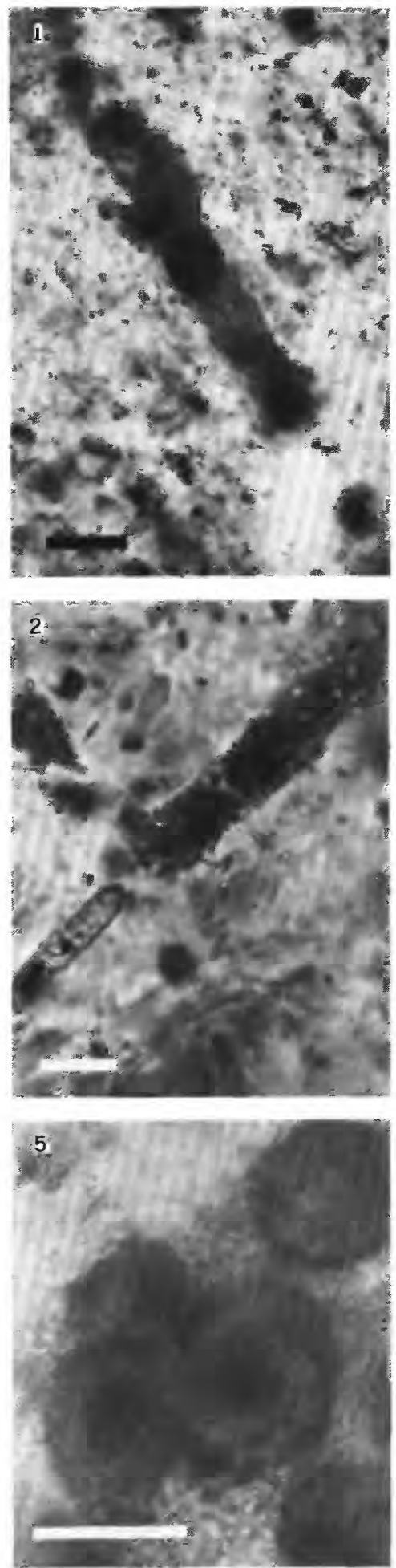
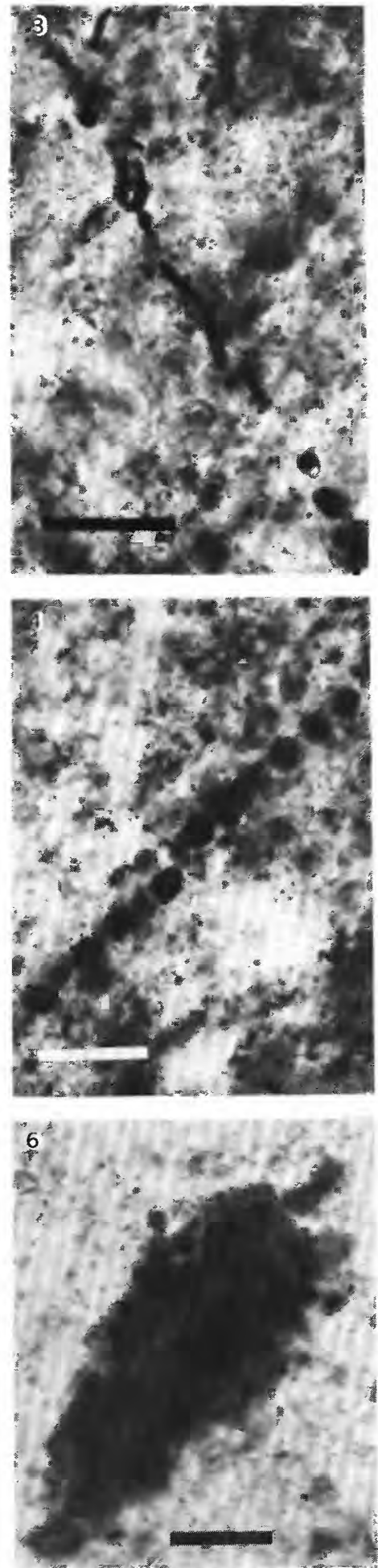

PROFESSIONAL PAPER 1449 PLATE 4
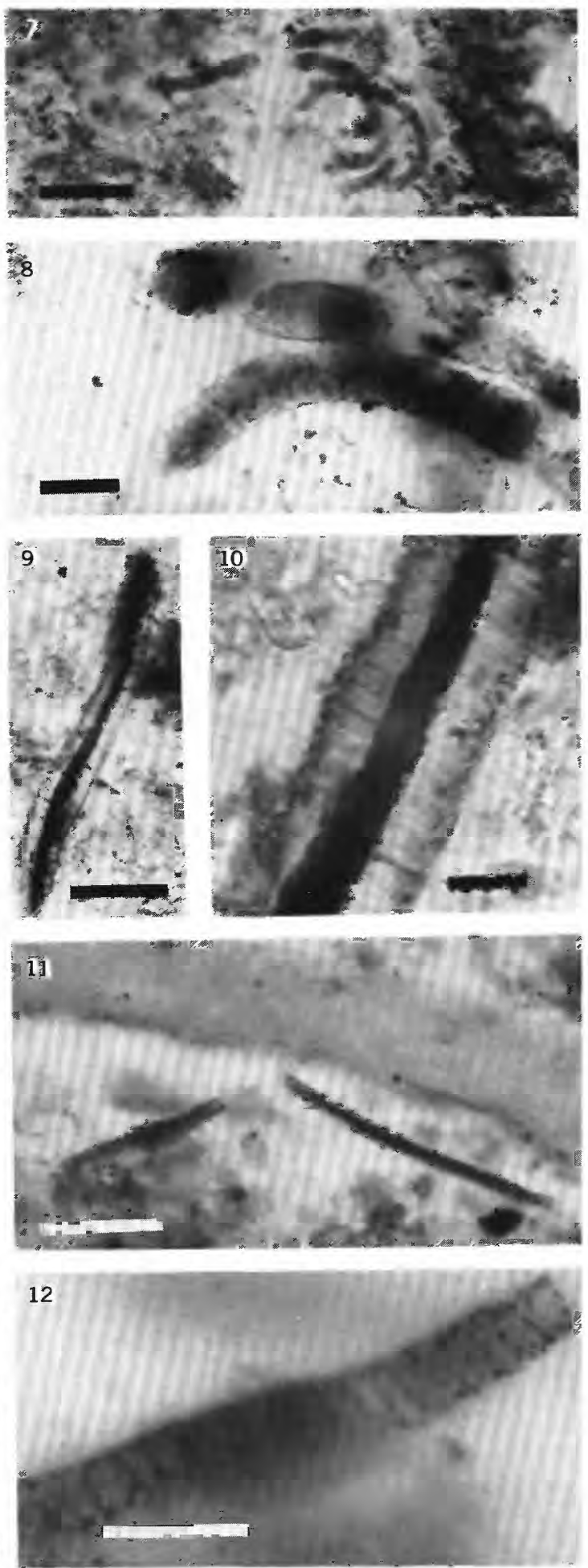

PALEONOSTOCALIA AND CYANOBACTERIAL(?) MICROFOSSILS 


\section{PLATE 5}

Enigmatic fungal(?) fossils from basalt and red beds unit(?) of the Tindir(?) Group, Washington Creek, Nation area

Figures 1-8. ?Fungi Type B from gray cherty shale. UAK A-1404.

1-3. Specimens exhibiting joint-like curving of filaments and spatial association of filaments and subangular bodies. Bars are $50 \mu \mathrm{m}$ long.

4, 5. Tapering filaments with bract-like extensions, distinctive arched branching, and short, thin, curved pieces that appear to have been associated with filaments. Bars are $10 \mu \mathrm{m}$ long.

6-8. Typical associations of apparently branching filaments and round to subangular bodies. Bars are $100 \mu \mathrm{m}$ long in figures 6 and 8; bar is $10 \mu \mathrm{m}$ in figure 7. 

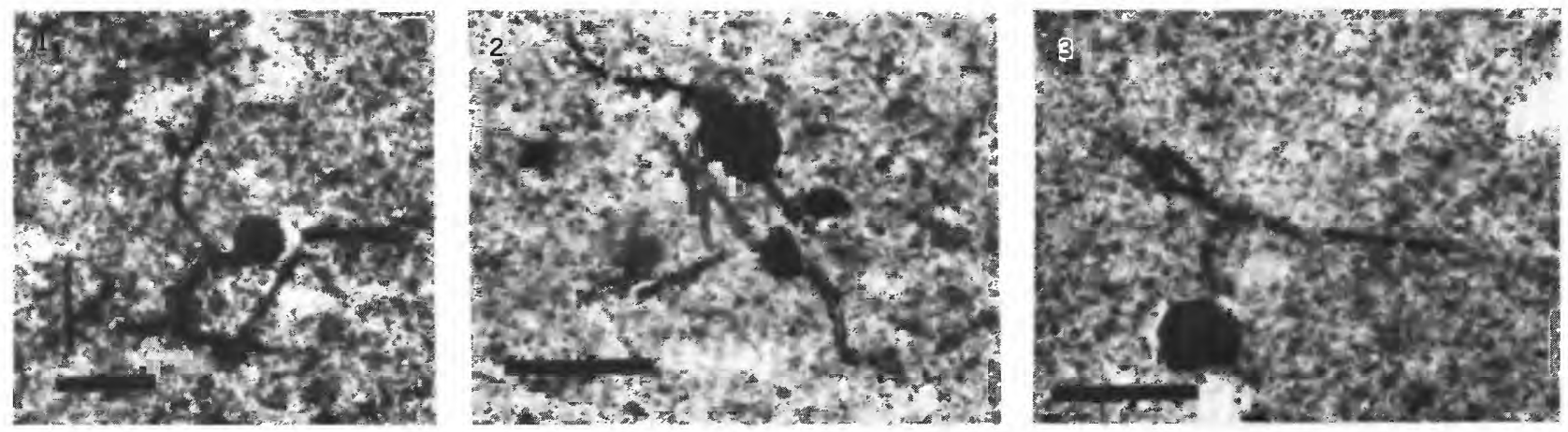
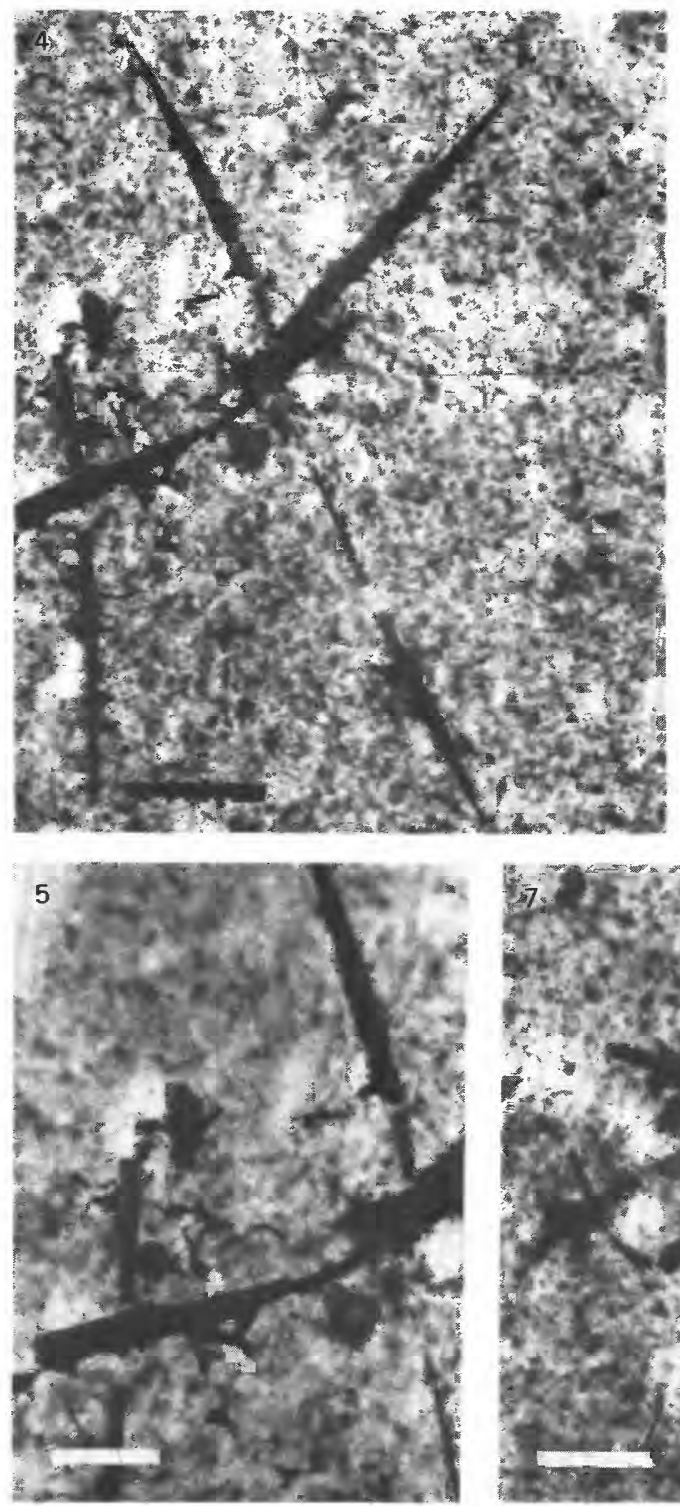

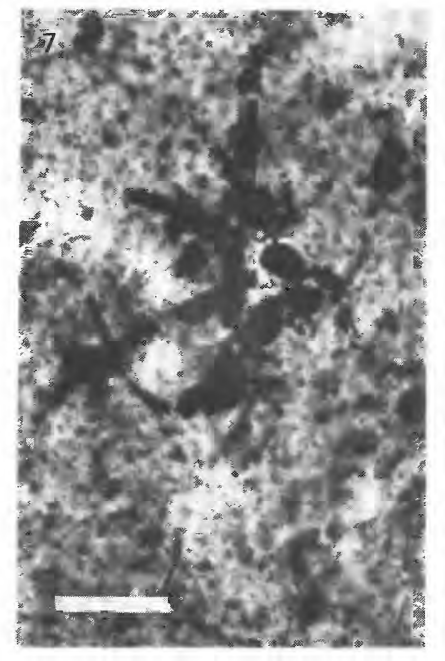

?FUNGI
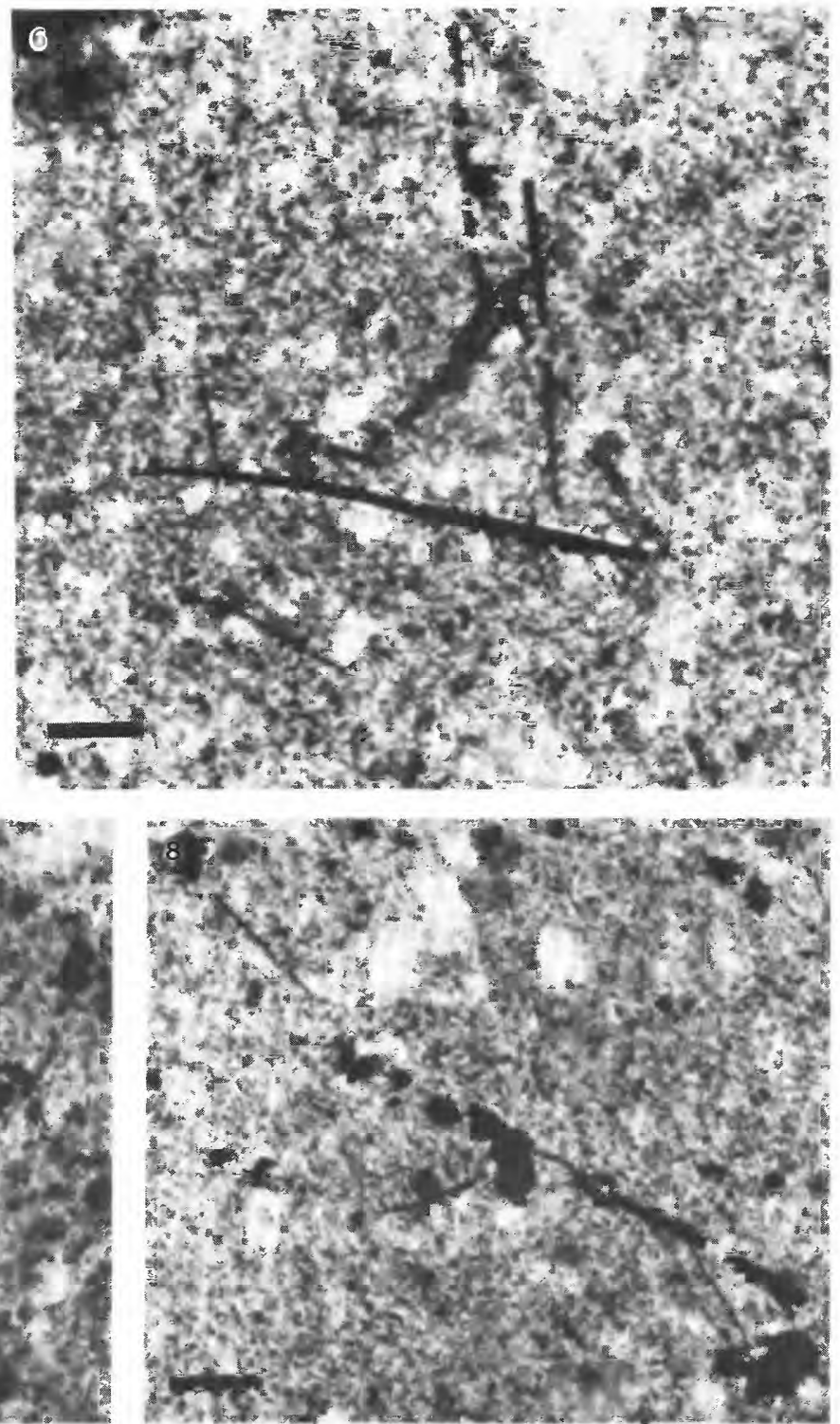


\section{PLATE 6}

Spicular fossils from basalt and red beds unit(?)

of the Tindir(?) Group, Washington Creek, Nation area

FIGURES 1-3. Chancelloria sp. UAK A-1395. Long ray in specimen shown in figure 1 appears to have small chamber-like structure on right near base. Clear channel forming the suture, shown in figure 3 , averages $7 \mu \mathrm{m}$ in width. Bar is $100 \mu \mathrm{m}$ long in figure 1 ; bars are $50 \mu \mathrm{m}$ long in figures 2 and 3.

4, 5. Clasts in matrix. UAK A-1395. Thready structures in specimen shown in figure 5 are of two general sizes: $1 \mu \mathrm{m}$ and $4 \mu \mathrm{m}$ in diameter. Those shown in figure 4 are part of a specimen of clearly spicular shape and range in diameter from 2 to $7.5 \mu \mathrm{m}$. Bars are $50 \mu \mathrm{m}$ long.

6, 7. Chancelloria sp. UAK A-1395. Polyactine spicule cut oblique to plane of central disk. Partial apparent ray pointing downward in figure 6 may be a proximal ray. Two long rays pointing upward exhibit evidence of thin-walled, convexly curved possible chamber at base. Pale areas are secondary calcite that has obliterated spicule structure in several areas. See text figure 12 for interpretation. Bar is $500 \mu \mathrm{m}$ long. Figure 7 shows suture between ray bases at lower right in figure 6 . Sinuous clear channel about $7 \mu \mathrm{m}$ wide contains dark fibrous structures 1.2 to $2.5 \mu \mathrm{m}$ in diameter. Bar is $25 \mu \mathrm{m}$ long. 
U.S. GEOLOGICAL SURVEY
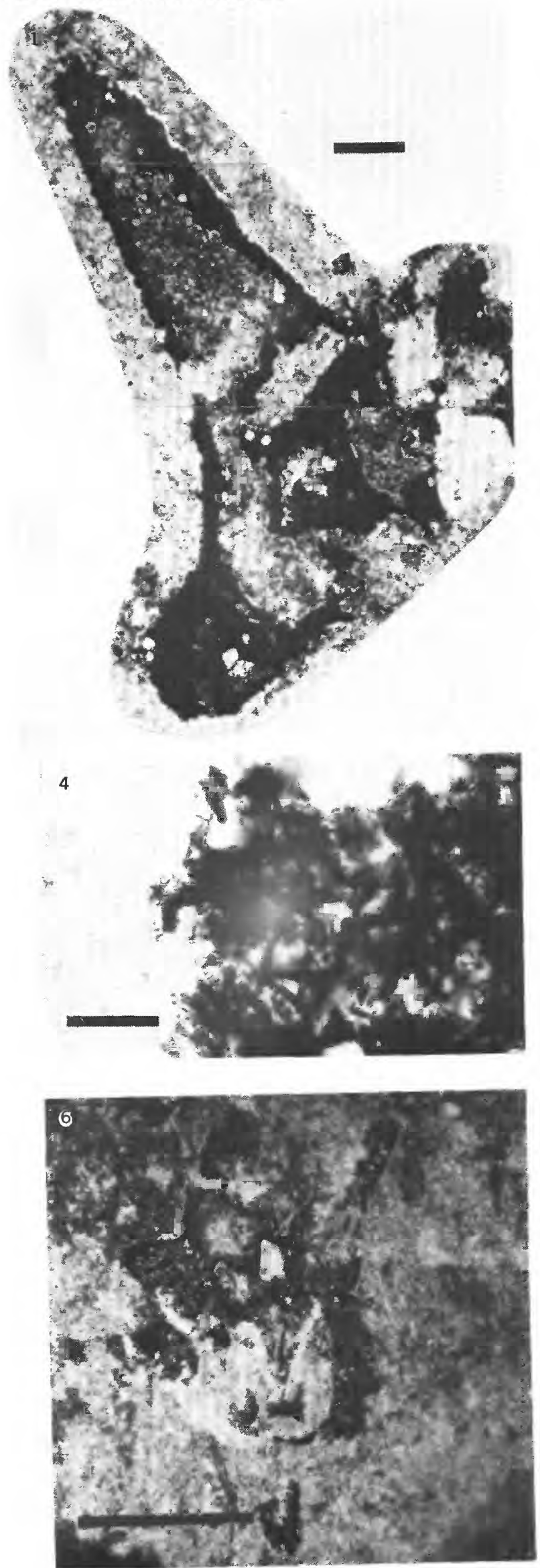

PROFESSIONAL PAPER 1449 PLATE 6
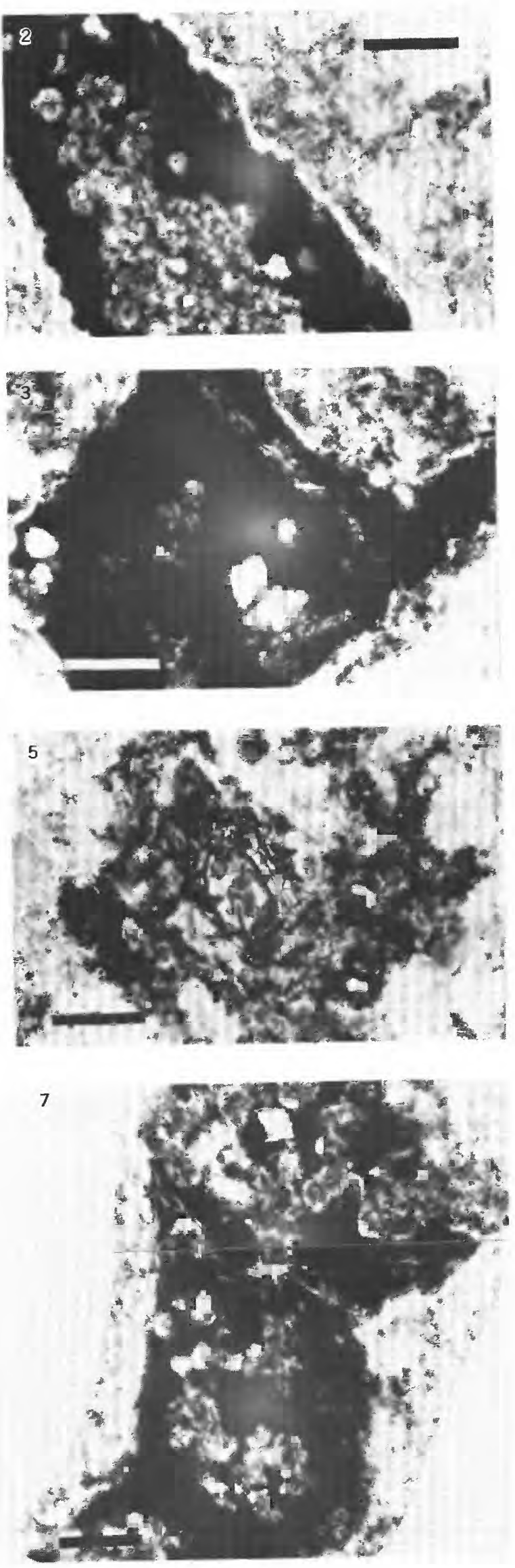


\section{PLATE 7}

Spicular fossils from basalt and red beds unit(?), of the Tindir(?) Group, Washington Creek, Nation area

FIGURES 1-3. Typical, long, slender, apparently stauract spicules of probable poriferan affinity. UAK A-1394. Bars are $50 \mu \mathrm{m}$ long.

4. ?Chancelloria Type A. Polyactine spicule having inflated rays and uncertain internal structure. Adjacent ray bases are not observable and may be sutured. UAK A-1395. Bar is $100 \mu \mathrm{m}$ long.

5-8. ?Chancelloria Type B. Small whorl-like structures composed of clear silica. These occur with abundant, larger, undoubted sponge spicules. UAK A-1402. Bars are $100 \mu \mathrm{m}$ long in figures 5, 6, and 8; bar is $10 \mu \mathrm{m}$ long in figure 7 . 
U.S. GEOLOGICAL SURVEY
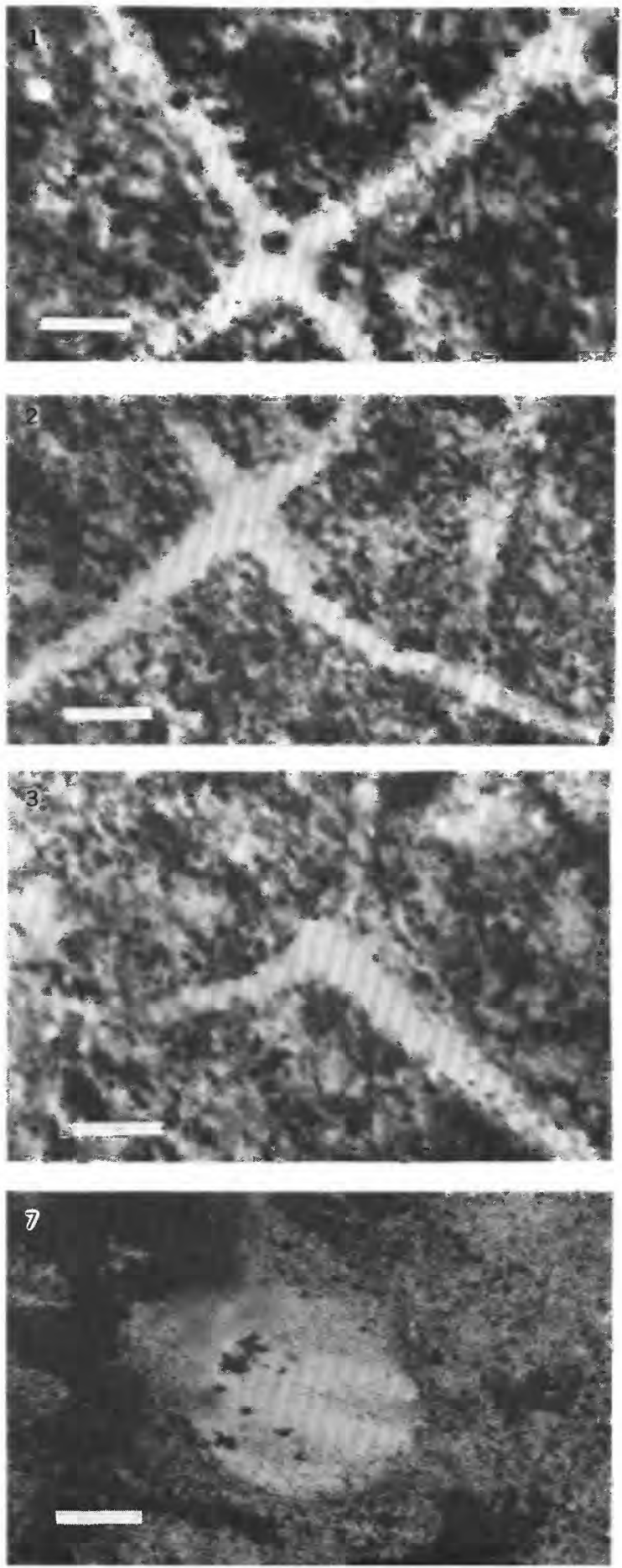

PROFESSIONAL PAPER 1449 PLATE 7
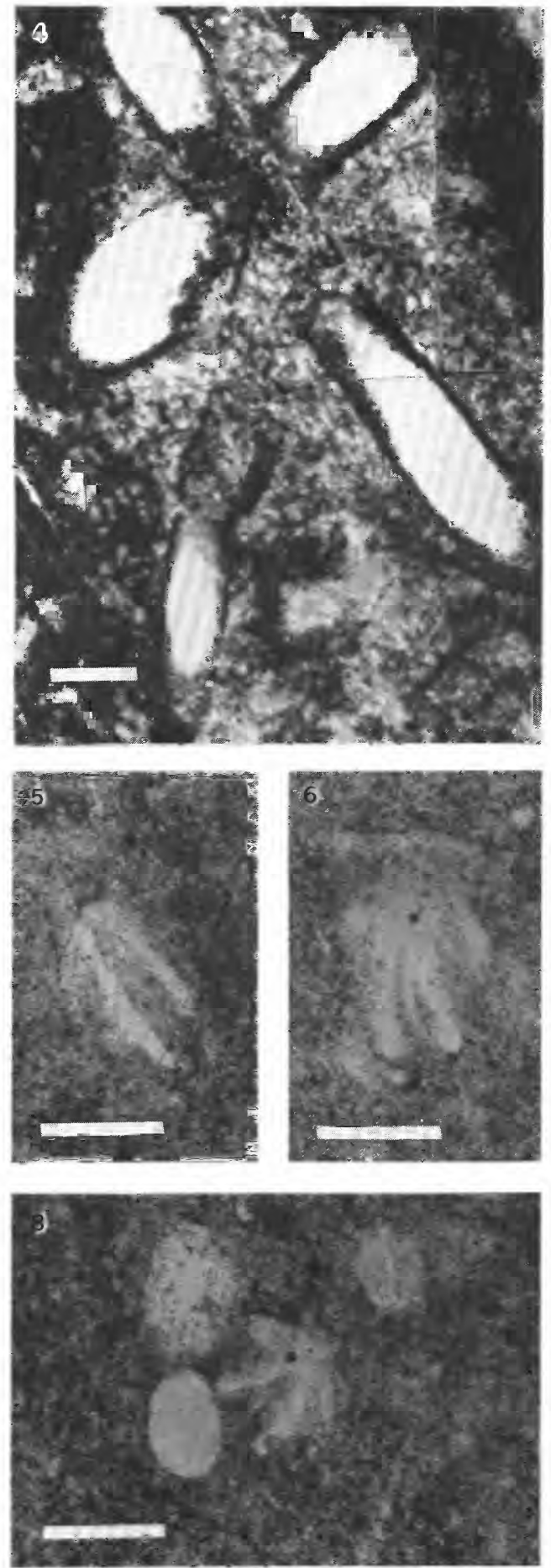

?CHANCELLORIA AND STAURACT SPICULES 


\section{PLATE 8}

Enigmatic fossils from basalt and red beds unit(?) of the Tindir(?) Group, Washington Creek, Nation area

FiguREs 1. Wedge-shaped fragment with dark bordering material on two sides. This specimen is similar to more complete chancelloriid spicules. UAK A-1395. Bar is $50 \mu \mathrm{m}$ long.

2. Short thread-like structures in subrounded clast. UAK A-1395. Bar is $50 \mu \mathrm{m}$ long.

3, 4. Pale-brown patch, $0.18 \mathrm{~mm}$ in size, in spicule-rich bed. Threads appear as soft, swirly structures with walls 4 to $8 \mu \mathrm{m}$ thick. Patch does not appear to be a clast and is unique in this biota. UAK A-1402. Bar is $50 \mu \mathrm{m}$ long in figure 3; bar is $25 \mu \mathrm{m}$ long in figure 4.

5-8. Slightly sinuous, long, branching(?), thready structures in pale-tan clasts. UAK A-1395. Threads shown in figures 6-8 have a lacy-appearing wall and appear to have been tubular. Bar is $100 \mu \mathrm{m}$ long in figure 5 ; bars are $10 \mu \mathrm{m}$ long in figures $6-8$. 
U.S. GEOLOGICAL SURVEY
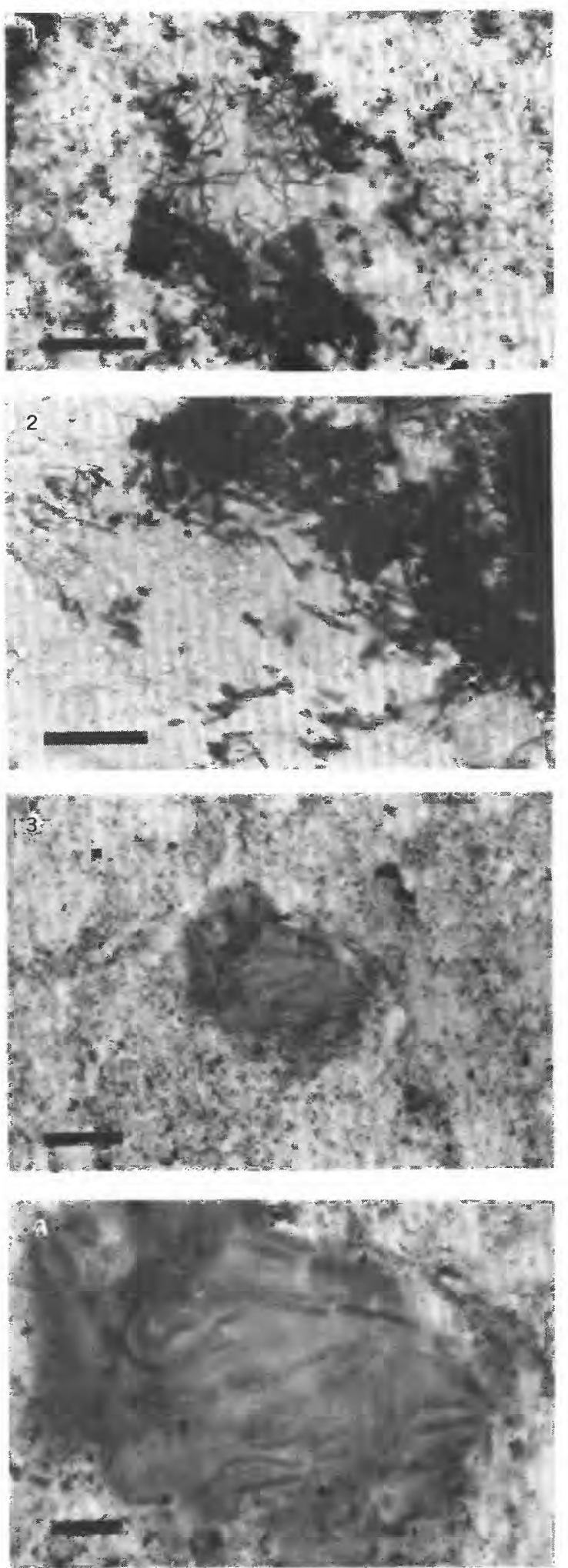

PROFESSIONAL PAPER 1449 PLATE 8
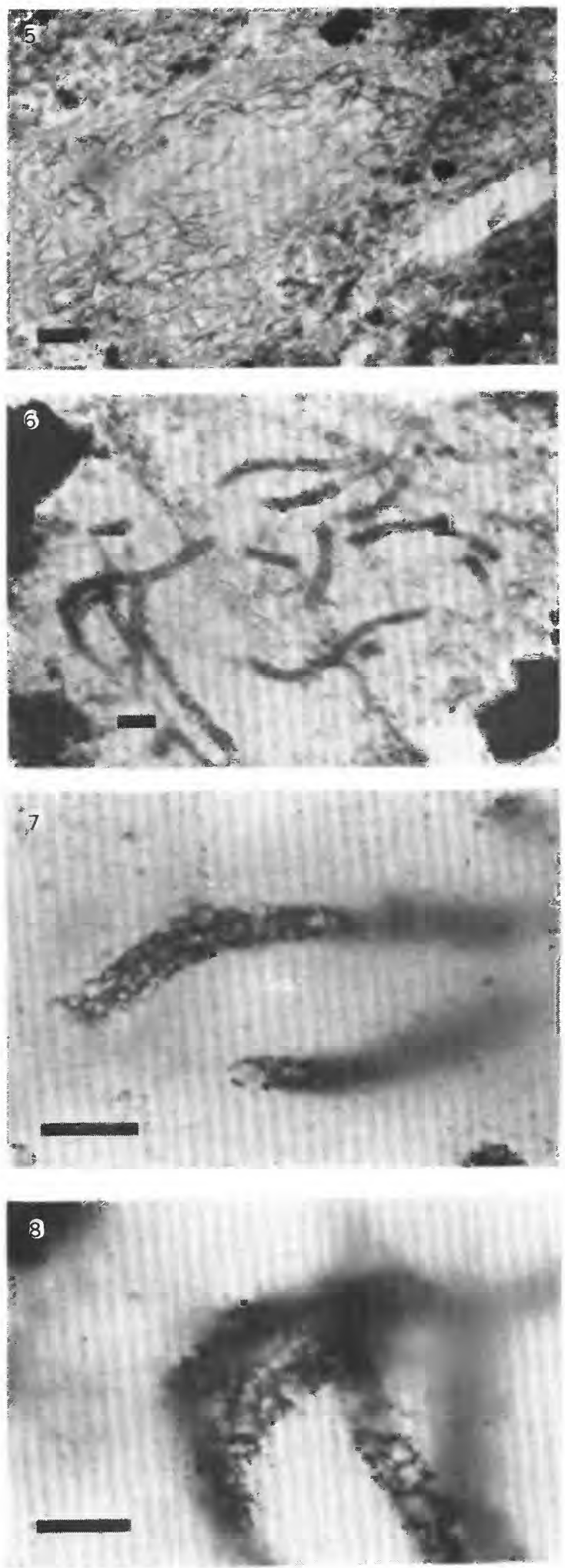

ENIGMATIC THREADY STRUCTURES 


\section{PLATE 9}

Enigmatic fossils from basalt and red beds unit(?)

of the Tindir(?) Group, Washington Creek, Nation area

Figures 1-3. ?Arthropoda Type B. Channel-like passages through layers of porous translucent material are about $2 \mu \mathrm{m}$ wide, and fragment is about $21 \mu \mathrm{m}$ thick. UCSB 544(17). Bar is $25 \mu \mathrm{m}$ long in figure 1 ; bars are $10 \mu \mathrm{m}$ long in figures 2 and 3.

4. ?Arthropoda Type A. UAK A-1395. Bar is $100 \mu \mathrm{m}$ long.

5. Incertae Sedis Type A. Multicellular (or multichambered), probably incomplete structure, $0.5 \mathrm{~mm}$ maximum dimension. Walls defining the four chambers are composed of silica grains oriented perpendicular to the wall. Note presence of apparent covering wall at lower right. UAK A-1395. Bar is $100 \mu \mathrm{m}$ long. 
U.S. GEOLOGICAL SURVEY
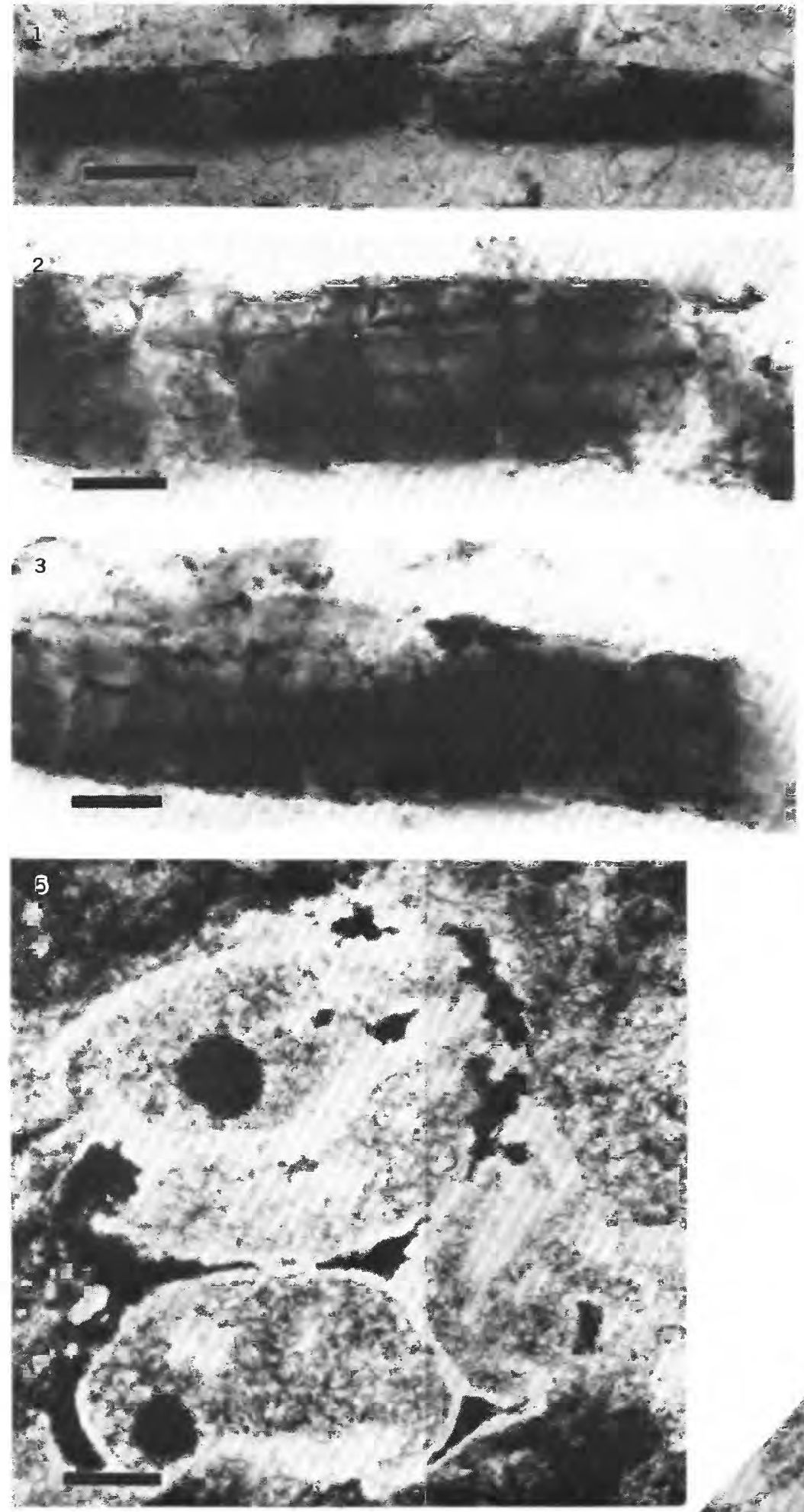

PROFESSIONAL PAPER 1449 PLATE 9

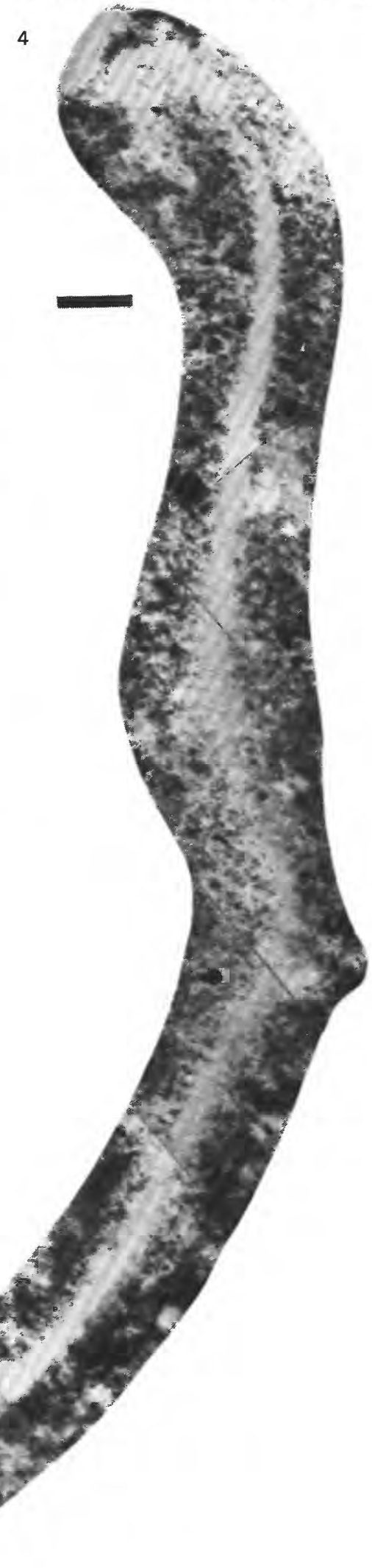

?ARTHROPODA AND INCERTAE SEDIS 


\section{PLATE 10}

Metazoan fossil from basalt and red beds unit(?) of the Tindir(?) Group, Washington Creek, Nation area

FIGUREs 1-5. Brabbinthes churkini Allison, 1975. UAK A-1392.

1. Total length is $0.45 \mathrm{~mm}$ and greatest width is $49 \mu \mathrm{m}$. Structure is unique in this biota except for a partial specimen that may represent the same type of fossil. Bar is $50 \mu \mathrm{m}$ long.

2-4. Anterior area at increasing focal depth. Slightly sinuous paired clear channels shown in figures 2 and 3 do not reach main axial canal seen in figure 5 . Bars are $10 \mu \mathrm{m}$ long.

5. Base of anterior projection showing nonchancelloriid structure. Bar is $10 \mu \mathrm{m}$ long. 

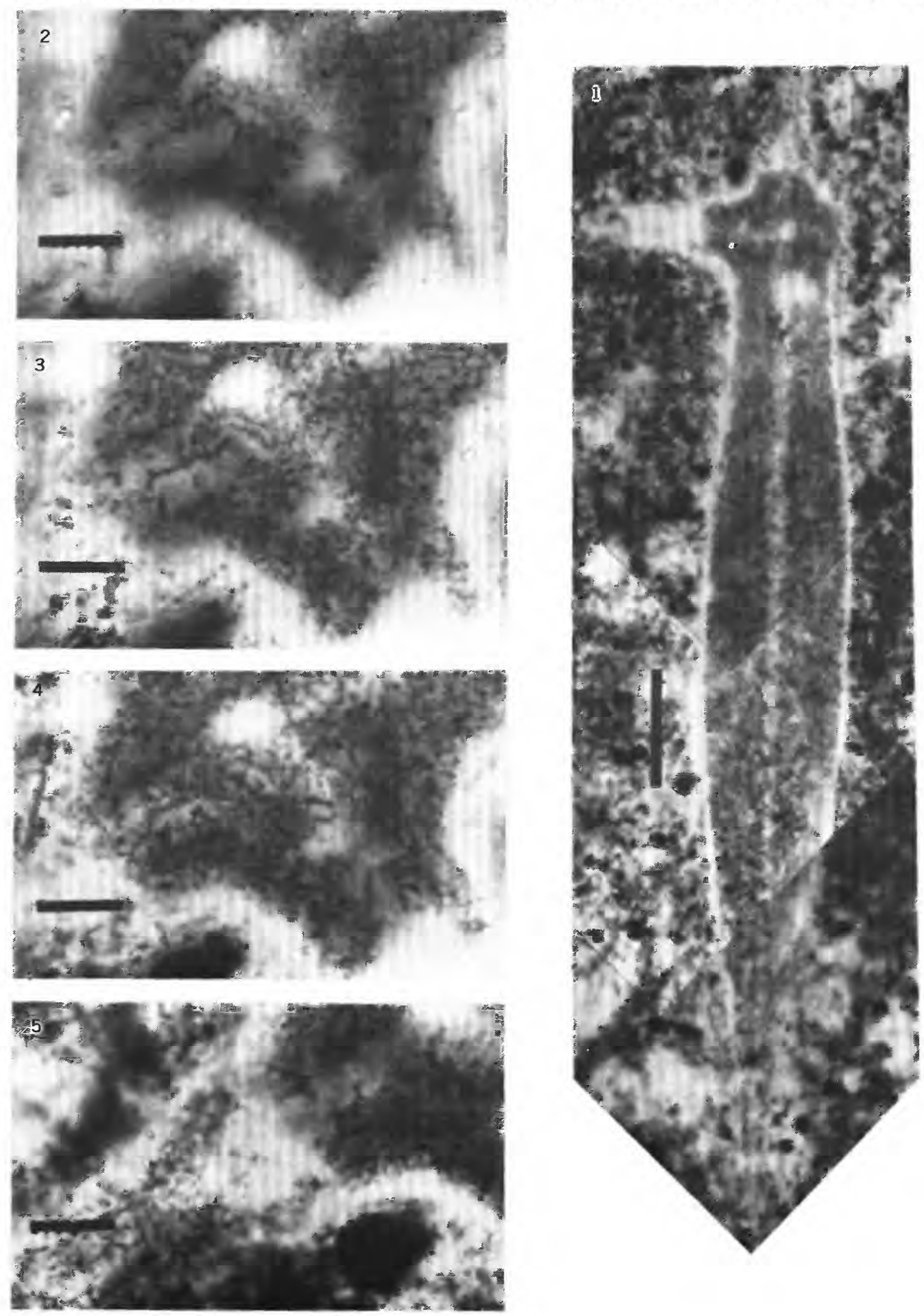

BRABBINTHES 


\section{PLATE 11}

Enigmatic fossils from basalt and red beds unit(?) of the Tindir(?) Group, Washington Creek, Nation area

FIGURES 1. Rounded structure containing spheres $4 \mu \mathrm{m}$ to $16 \mu \mathrm{m}$ in diameter. Spheres appear to be thin-walled cells of a type and organization unique in biota at Washington Creek. UAK A-1392. Bar is $50 \mu \mathrm{m}$ long.

2, 3. Protista Incertae Sedis Type G. UAK A-1392. Pale material inside peripheral ring of spheres is secondary silica without evident organization. Bars are $50 \mu \mathrm{m}$ long.

4-6. Enigmatic silica-rimmed structures described as Incertae Sedis Type C. UAK A-1392. Rim 3 to $5 \mu \mathrm{m}$ thick. Silica rim of specimen shown in figure 6 extends to lower right around two smaller dark patches of similar material. Bars are $10 \mu \mathrm{m}$ long.

7, 8. Unnamed multirayed form that may be poriferan. UAK A-1392. Bars are $100 \mu \mathrm{m}$ long. 
U.S. GEOLOGICAL SURVEY
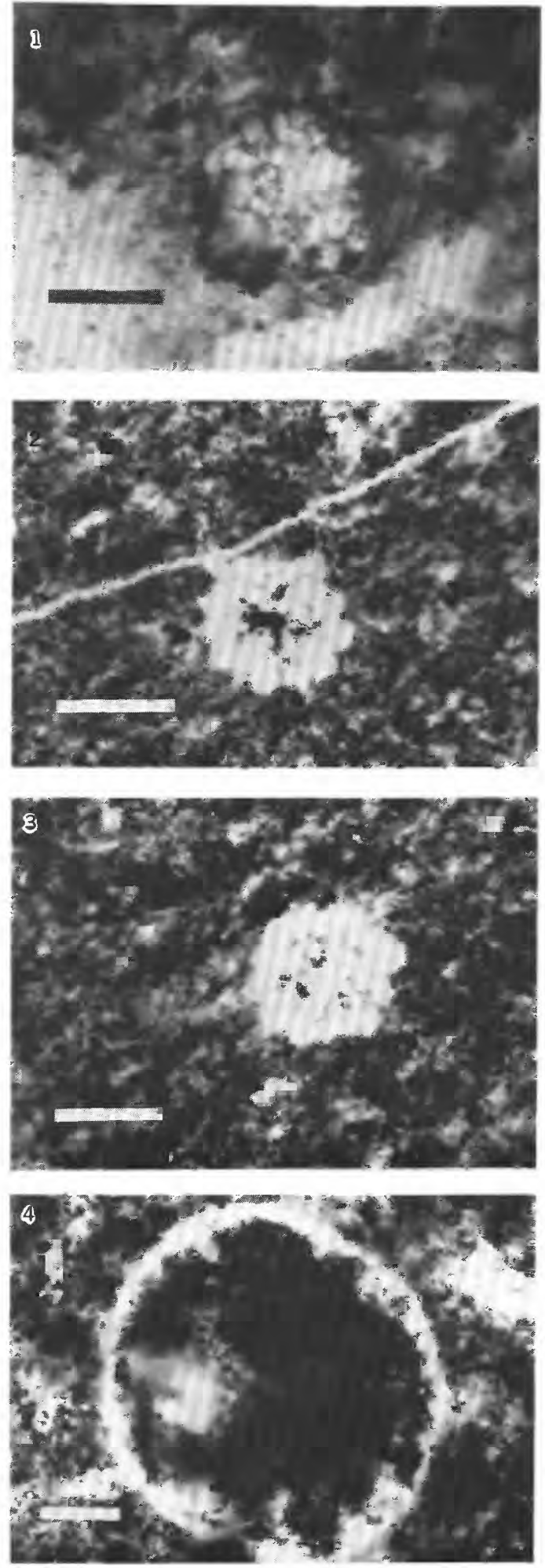

PROFESSIONAL PAPER 1449 PLATE 11
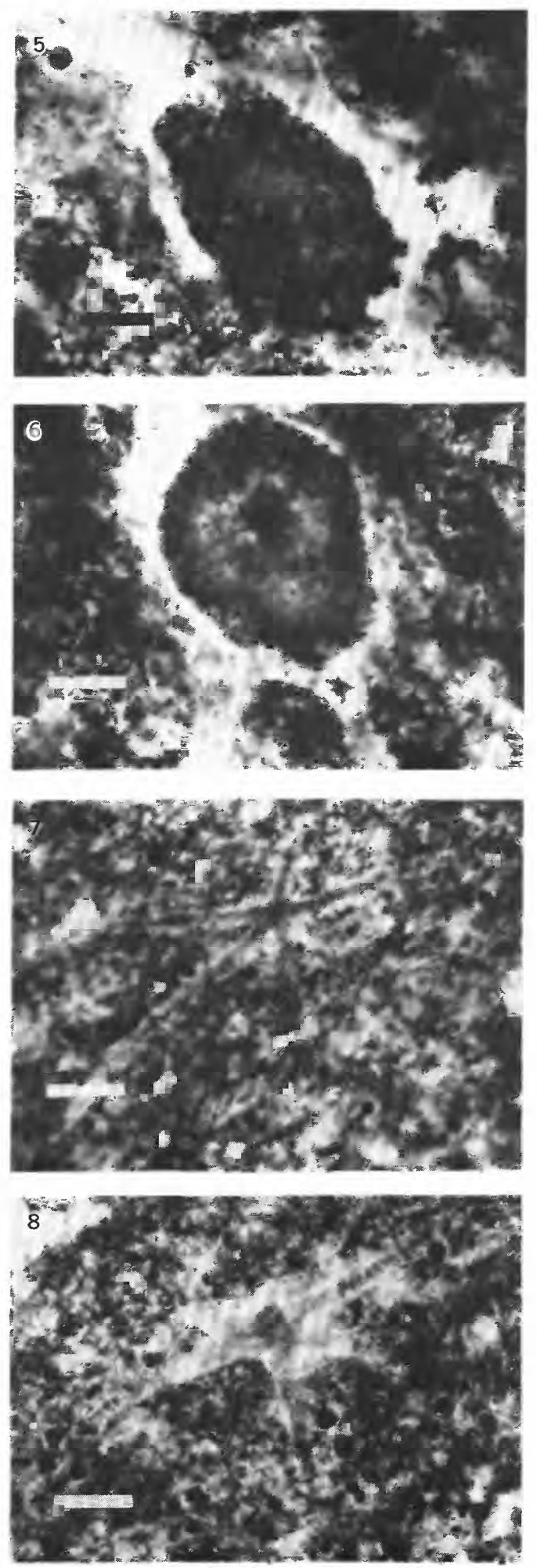

PROTISTA, ?PORIFERA, AND ENIGMATIC MICROFOSSILS 


\section{PLATE 12}

Fungi and coccoid fossils from Woodchopper area

Figures 1-7. Cylindromyces septatus n. gen and sp. from Takoma Bluff. UAK A-1408.

1-4. Typical curvature and association of filaments. Evidence of septation is present in specimens shown in figures 2 and 3 . Occasional scattered spherical cells are present in all these specimens. Bars are $50 \mu \mathrm{m}$ long.

5,6 . Apparently branched specimen. Terminal segment, shown at higher magnification in figure 6 , contains spherical bodies 4 to $10 \mu \mathrm{m}$ in diameter. Bar is $150 \mu \mathrm{m}$ long in figure 5 ; bar is $25 \mu \mathrm{m}$ long in figure 6 .

7. Fragment of filament with one multiunit inside, seen here as a dark sphere near center of photograph. This is the only specimen containing an internal body other than thin-walled spheres. Multiunits of this type are common in the matrix and appear to be associated with co-occurring cyanobacterial Sphaerocongregus. Bar is $25 \mu \mathrm{m}$ long.

8, 9. Protista Incertae Sedis Type E from Takoma Bluff. UAK A-1408. Two of eighteen multiunit spheres composing this fossil lie at inner right end in figure 8. See text figure 11 for interpretation. Subunits in multiunit, shown in figure 9 , are very closely packed. Bar is $100 \mu \mathrm{m}$ long in figure 8; bar is $10 \mu \mathrm{m}$ long in figure 9.

10. Endosporangium of Sphaerocongregus variabilis. Note stream of released spores above endosporangium. UAK A-1408. Bar is $10 \mu \mathrm{m}$ long. 
U.S. GEOLOGICAL SURVEY
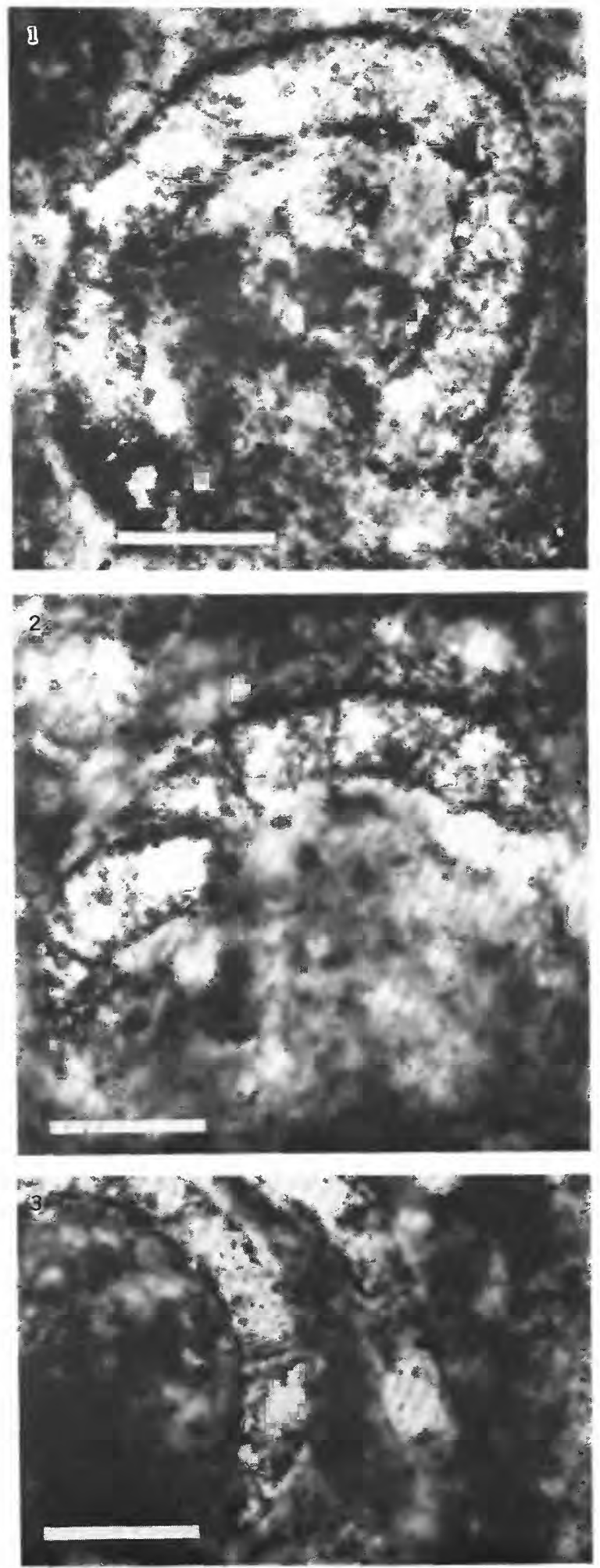

PROFESSIONAL PAPER 1449 PLATE 12
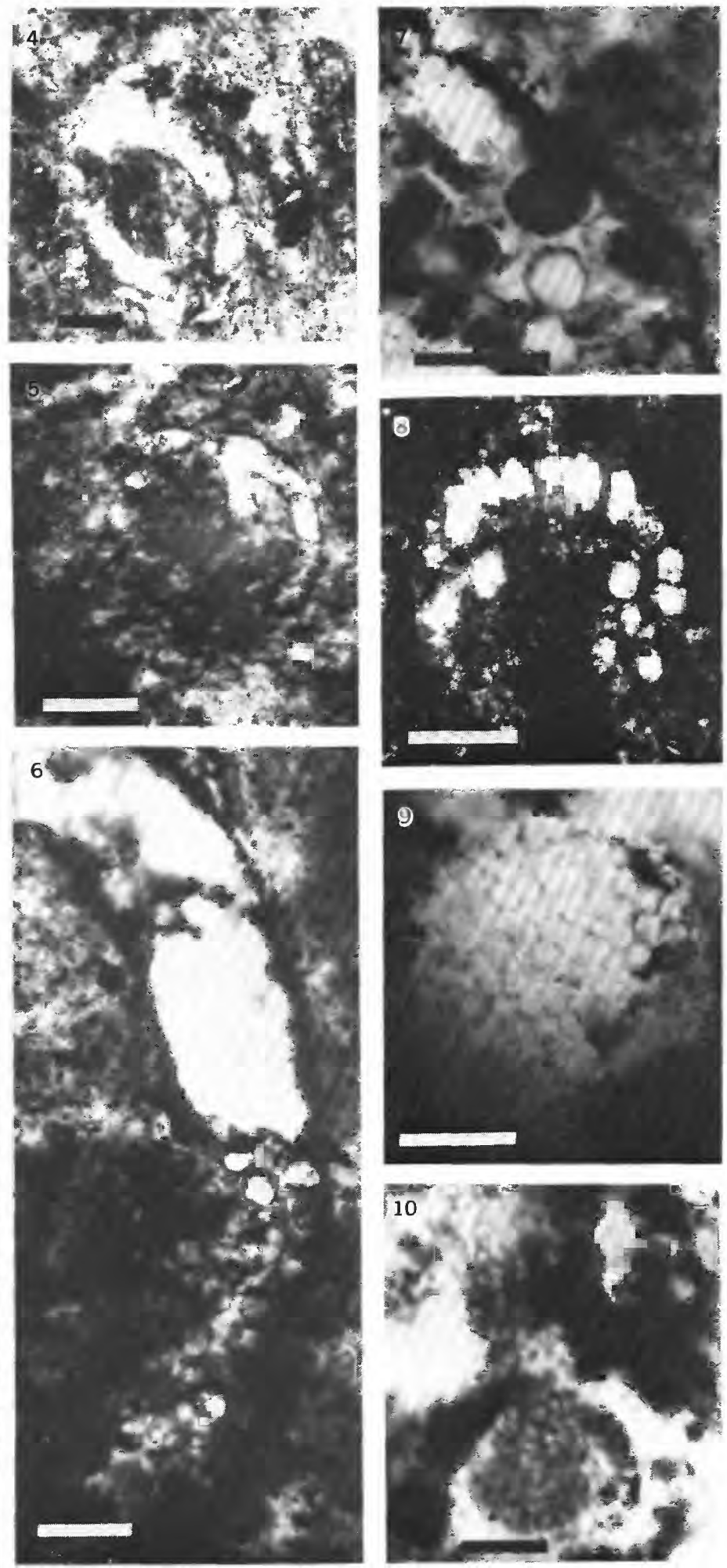

CYLINDROMYCES, SPHAEROCONGREGUS, AND PROTISTAN MICROFOSSILS 


\section{PLATE 13}

Fungi and Cyanobacteria from Woodchopper area

Figures 1-8. ?Fungi Oval Spores Type A and Type B from Takoma Bluff. UAK A-1408.

1-3. Oval Spore Type A. Dark stellate area in specimen shown in figure 3 probably reflects crushing of spore. Bars are $10 \mu \mathrm{m}$ long.

4-6. Oval Spore Type B. More rounded appearance of specimen shown in figure 6 suggests orientation with end of spore pointed toward viewer. Bars are $10 \mu \mathrm{m}$ long.

7. Opaque, crushed Oval Spore Type A. Most specimens observed are of this nature of preservation. Bar is $10 \mu \mathrm{m}$ long.

8. Oval Spore Type A with complete phyllosilicate envelope. Bar is $20 \mu \mathrm{m}$ long. 9, 10. Endosporangia of Sphaerocongregus variabilis with well-preserved spores. UAK A-1408. Bars are $10 \mu \mathrm{m}$ long. 

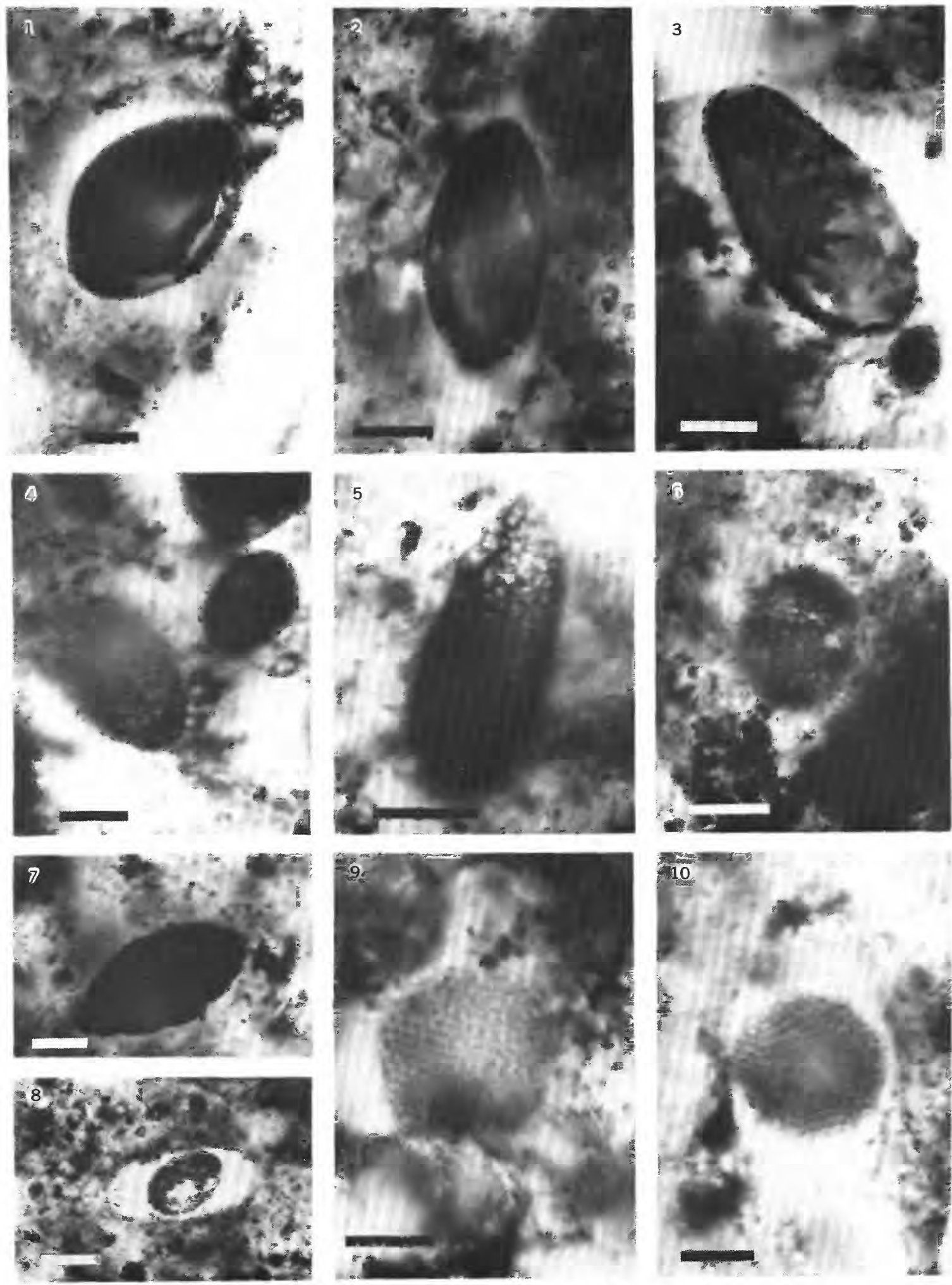

SPHAEROCONGREGUS, ? FUNGI 


\section{PLATE 14}

?Fungi and Cyanobacteria from Woodchopper area

[Scanning electron micrographs of macerated material by M.A. Moorman at University of Alaska.]

FIGURES 1, 2. Endosporangia of Sphaerocongregus variabilis from Takoma Bluff. UAK A-1408. Bar is $5 \mu \mathrm{m}$ long in figure 1 ; bar is $1 \mu \mathrm{m}$ long in figure 2 .

3, 5, 6. ?Fungi Oval Spore Type A from Takoma Bluff. UAK A-1408. Bars are $5 \mu \mathrm{m}$ long.

4. ?Fungi Oval Spore Type B from Takoma Bluff. UAK A-1408. Pronounced rugosity may reflect degradation of sculptured surface. Bar is $5 \mu \mathrm{m}$ long. 


\section{U.S. GEOLOGICAL SURVEY}
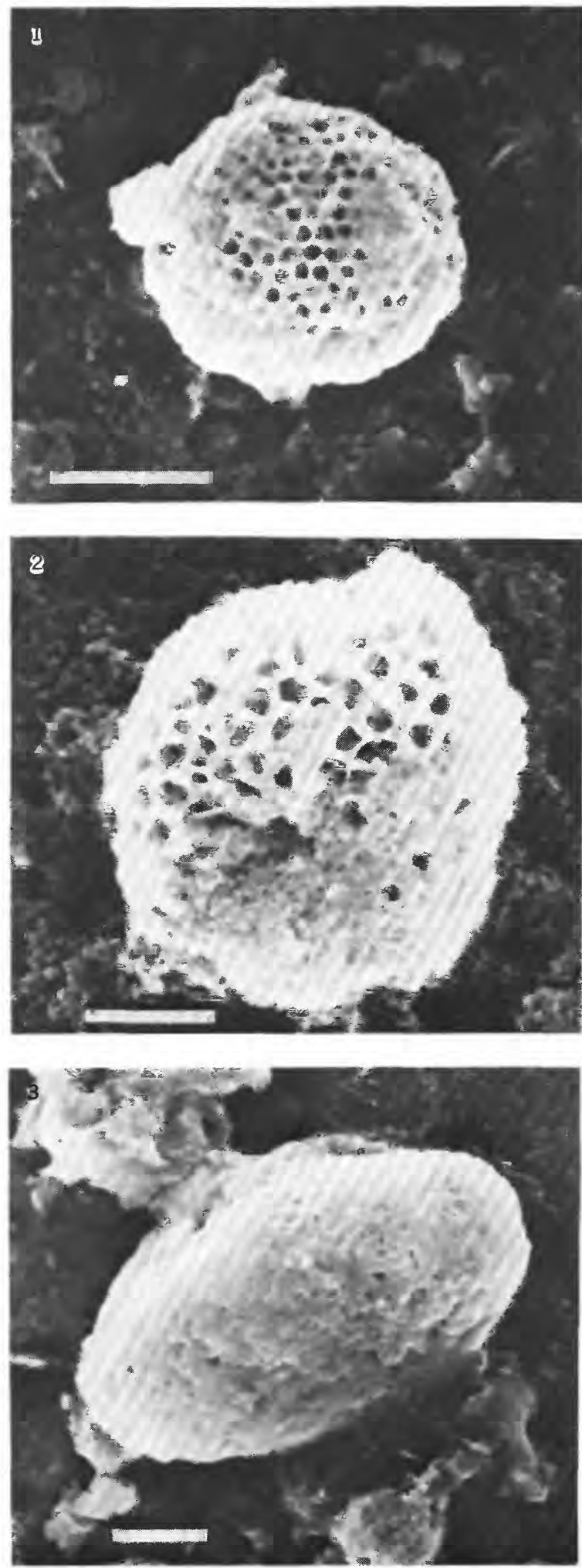

SPHAEROCONGREGUS, ?FUNGI

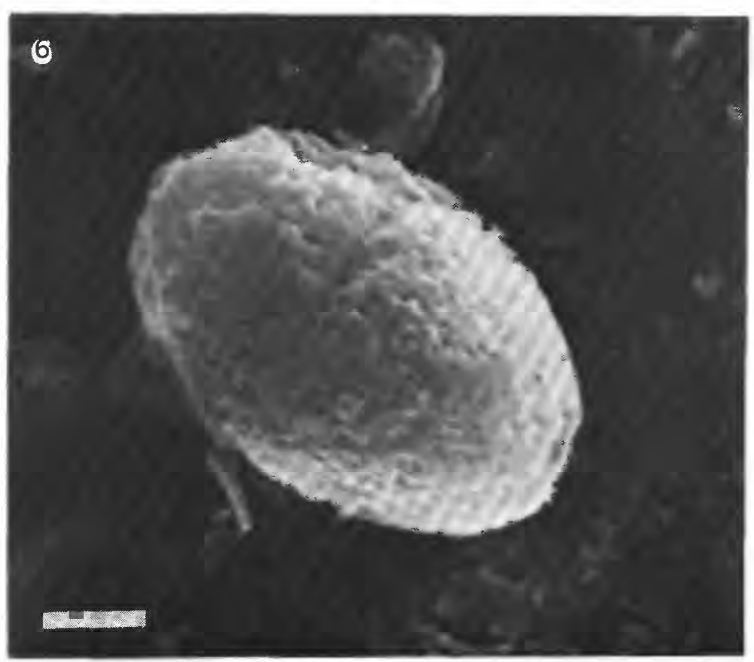

PROFESSIONAL PAPER 1449 PLATE 14
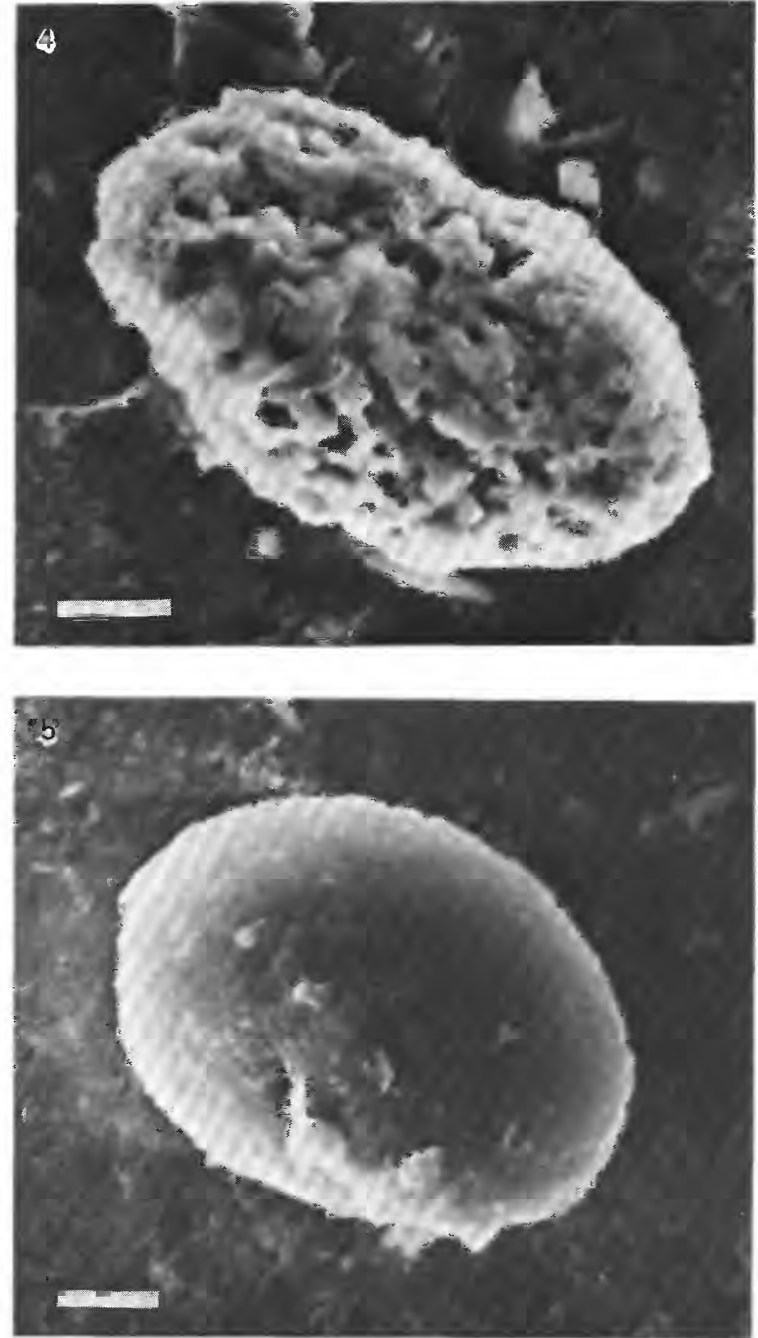
PLATE 15

Cyanobacteria from Woodchopper area

FIGURES 1-8. Sphaerocongregus variabilis from Takoma Bluff. UAK A-1409.

1, 2. Multilayered chain $130 \mu \mathrm{m}$ long and about $19.1 \mu \mathrm{m}$ wide. Note band of phyllosilicate bordering specimen at top and bottom. Outer margin of these bands occasionally reflects arrangement of neighboring cells, as in this specimen. Bar is $25 \mu \mathrm{m}$ long in figure 1; bar is $10 \mu \mathrm{m}$ long in figure 2 .

3. Unusual group of cells probably representing continuing division of the type producing the more common multilayered chains as shown in figures 1 and 2. Most cells in this specimen are 4 to $8 \mu \mathrm{m}$ in diameter; a few smaller bodies 0.96 to $1.5 \mu \mathrm{m}$ in diameter are probably also cells. Bar is $10 \mu \mathrm{m}$ long.

4-6. Groups of cells exhibiting inequal division. Bars are $10 \mu \mathrm{m}$ long.

7, 8. Long pseudofilament exhibiting formation of multilayered chain at an early stage. Bars are $10 \mu \mathrm{m}$ long. 
U.S. GEOLOGICAL SURVEY
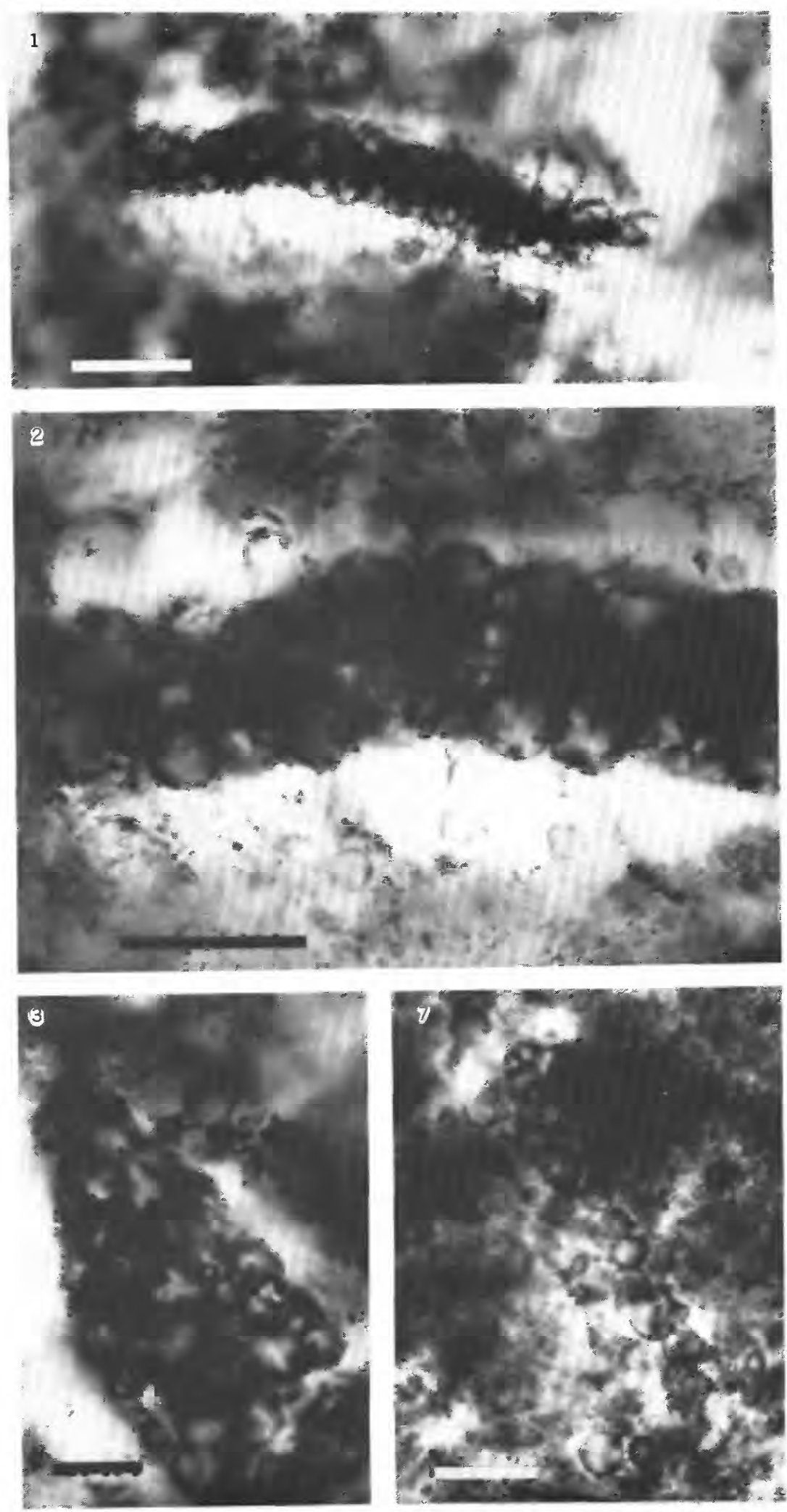
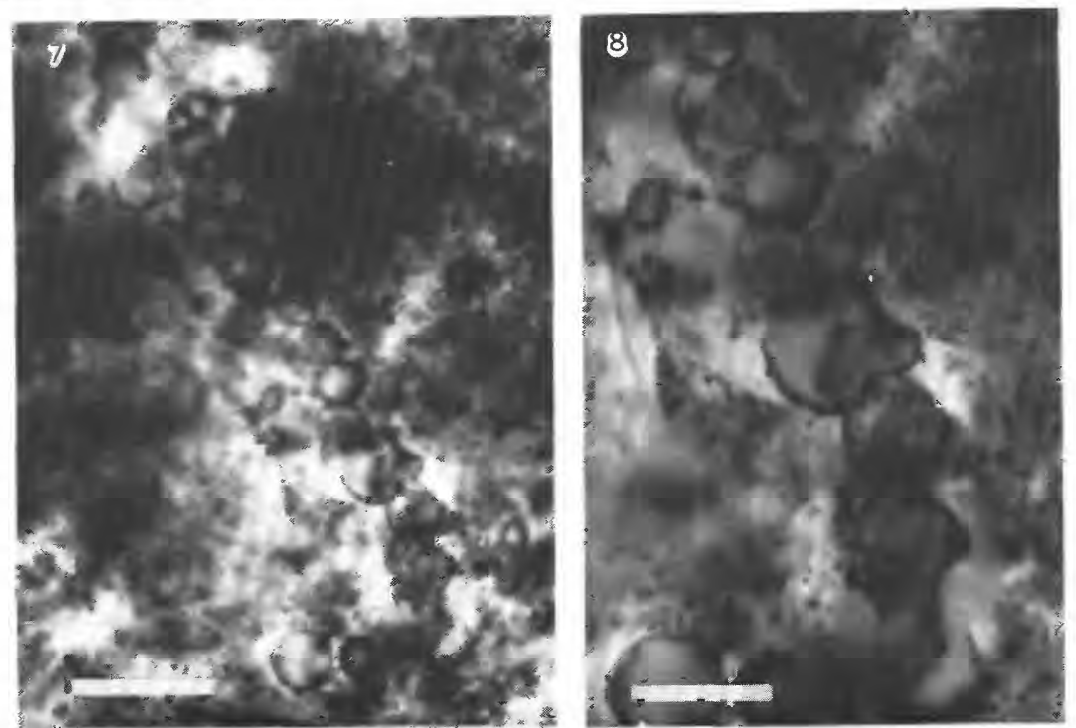

SPHAEROCONGREGUS
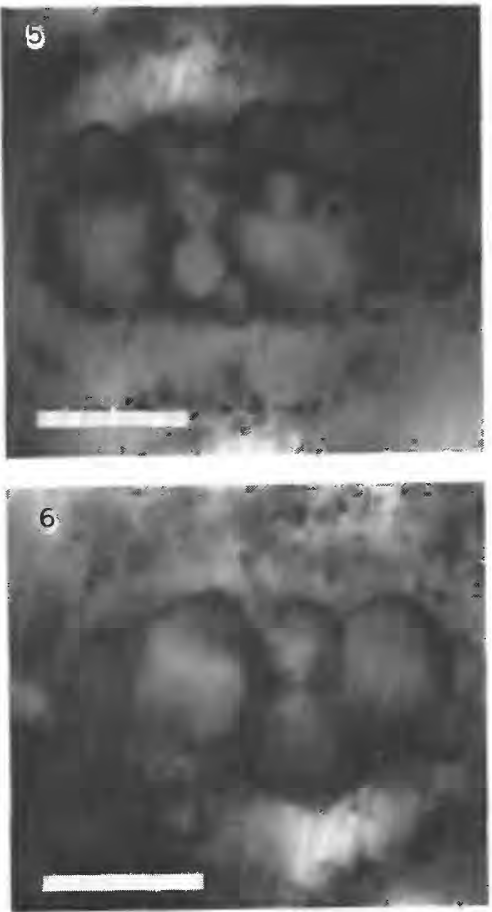


\section{PLATE 16}

Cyanobacteria and enigmatic protistans from Woodchopper area

FIgUREs 1, 2. Smooth-walled unicells of Sphaerocongregus variabilis from Takoma Bluff. UAK A-1409. Note presence of bright spots in some cells. These appear as fluid under polarized light. Bars are $25 \mu \mathrm{m}$ long.

3, 4. Endosporangia of $S$. variabilis. UAK A-1409. Bars are $10 \mu \mathrm{m}$ long.

5, 6. Protista Incertae Sedis Type F. UAK A-1409. Pale siliceous rim about $1 \mu \mathrm{m}$ thick envelops finely granular brown material. Irregular pale area in center of specimen shown in figure 6 reflects presence of nongranular internal areas in some specimens of this fossil. Bars are $10 \mu \mathrm{m}$ long.

7. Unusual cluster of cells that occur with abundant Sphaerocongregus in an atypical association. UAK A-1409. Bar is $5 \mu \mathrm{m}$ long.

8. Protista Incertae Sedis Type D. UAK A-1409. C-shaped structure in center is clear organic material similar to outer wall. Bar is $10 \mu \mathrm{m}$ long.

9-12. Chains of coccoid cells probably representing Sphaerocongregus variabilis. Cells range from 8 to $10 \mu \mathrm{m}$ in diameter; a few much smaller spheres are present in two specimens. UAK A-1409. Bars are $25 \mu \mathrm{m}$ long. 
U.S. GEOLOGICAL SURVEY
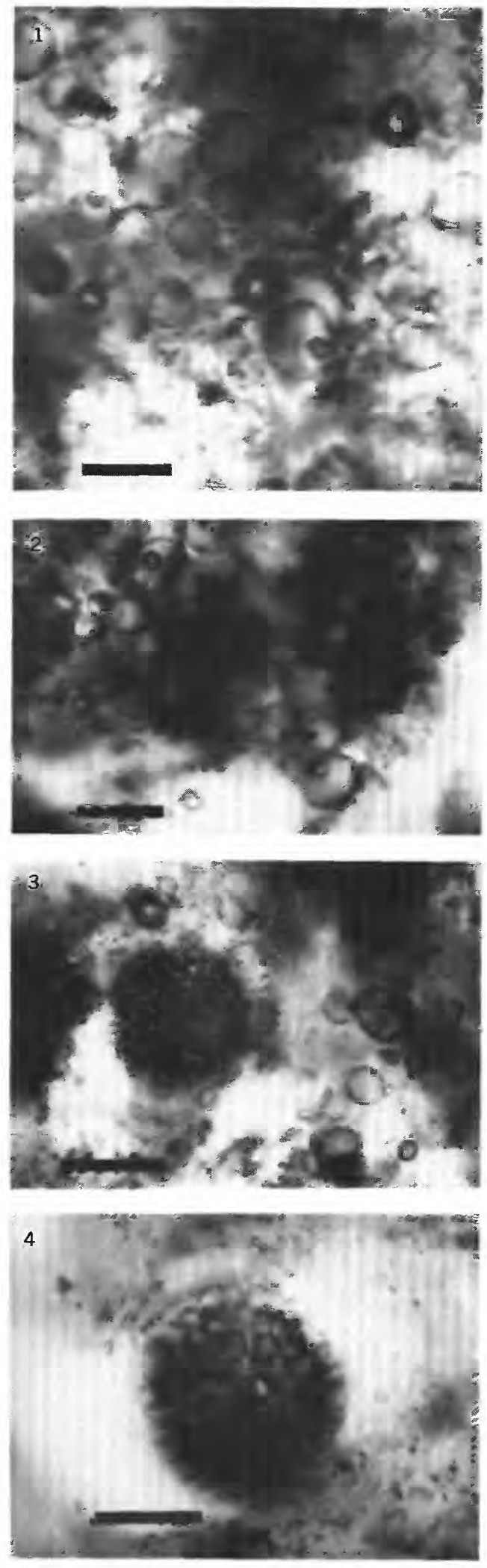

PROFESSIONAL PAPER 1449 PLATE 16
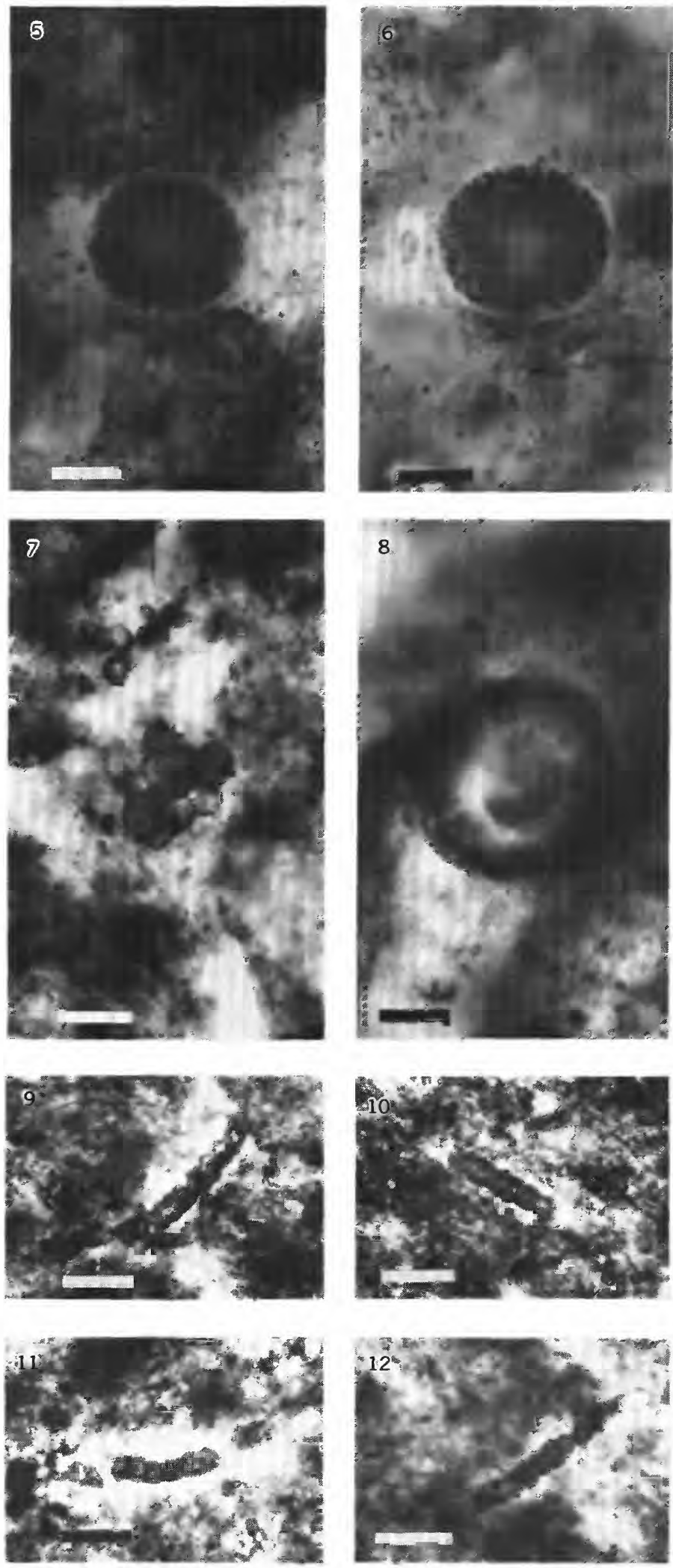


\section{PLATE 17}

Enigmatic acritarchs and protistans from the southeastern Woodchopper area

Figures 1-3, 5. Acanthomorph Acritarcha Type A. USGS 62ABa2132. Figures 2 and 3 of same specimen at different focal depths. Note tight cluster of cells, referred to Protista Incertae Sedis Type A, to upper right in figure 5 . Bars are $25 \mu \mathrm{m}$ long.

4. Acanthomorph Acritarcha Type B. USGS 62ABa2132. Bar is $25 \mu \mathrm{m}$ long.

6-8. Protista Incertae Sedis Type A. USGS 62ABa2132. Bar is $25 \mu \mathrm{m}$ long in figure 6; bar is $50 \mu \mathrm{m}$ long in figure 7; bar is $5 \mu \mathrm{m}$ long in figure 8 .

9. Protista Incertae Sedis Type B. USGS $62 A B a 2132$. Pale-brown, very thin walled specimen with single tapering process that flares slightly at tip. Bar is $25 \mu \mathrm{m}$ long. 
U.S. GEOLOGICAL SURVEY
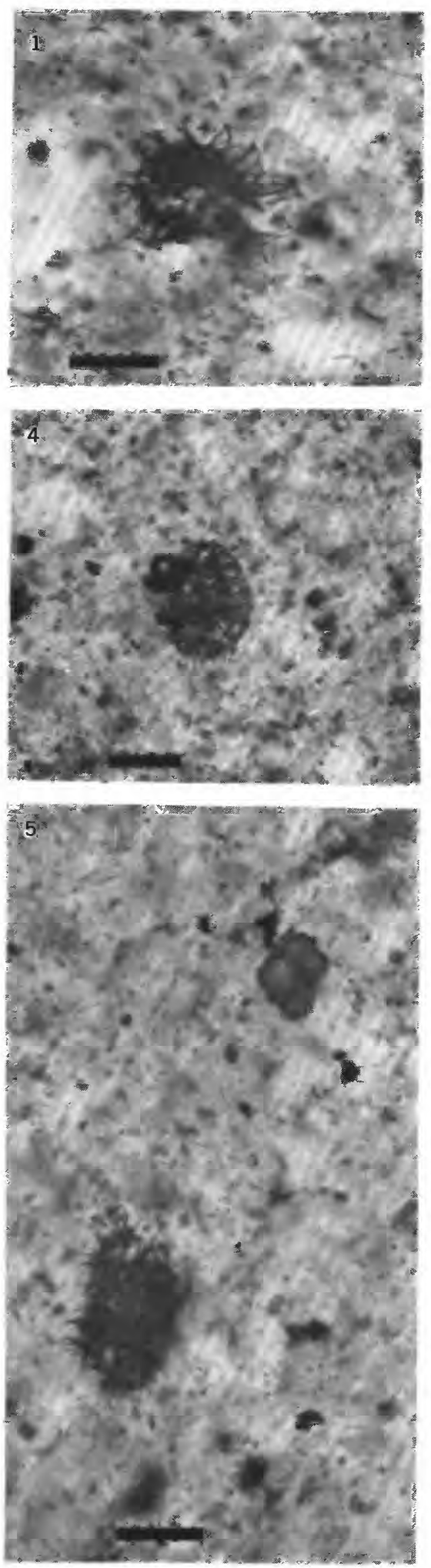

PROFESSIONAL PAPER 1449 PLATE 17
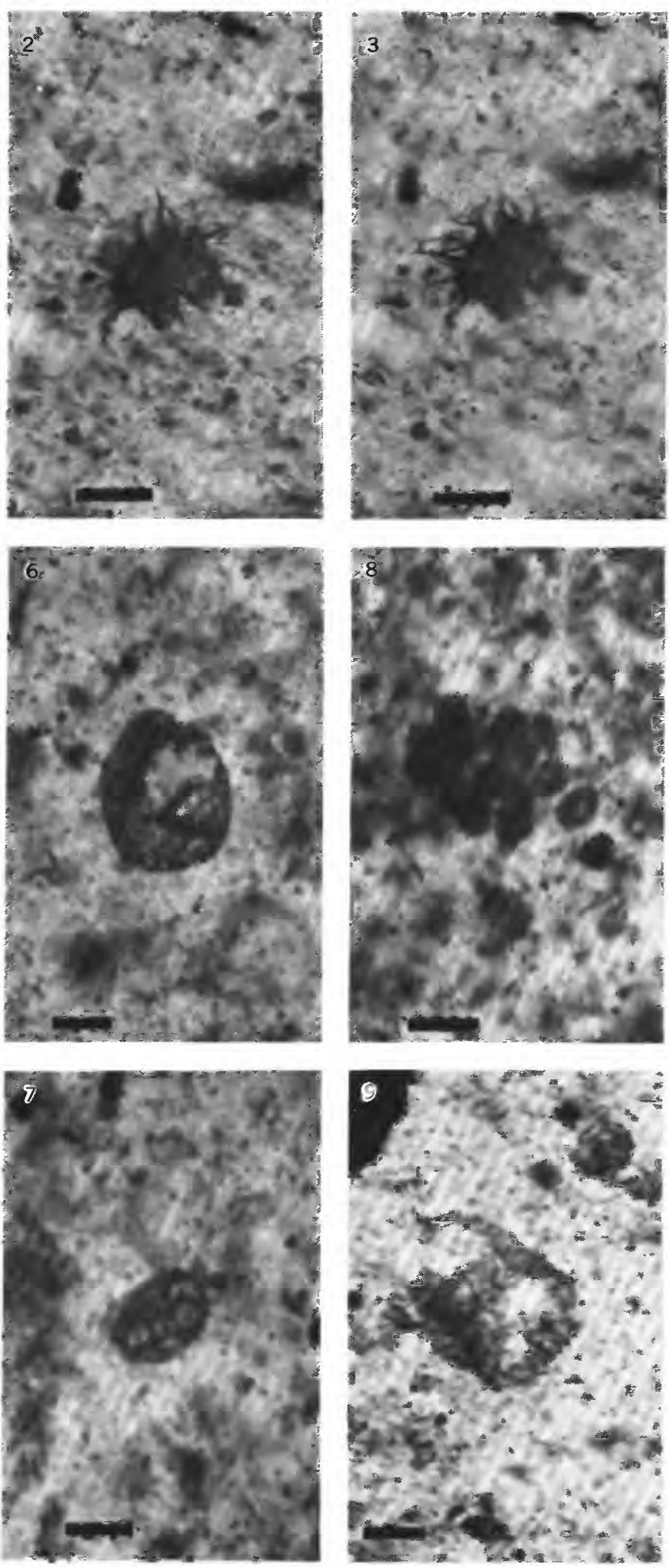


\section{PLATE 18}

Miscellaneous fossils from Tatonduk, Nation, and Woodchopper areas

Figures 1. ?Oldhamia from the undivided sedimentary rocks unit in Edwards Creek, Woodchopper area. USGS 63ABa4176. Scattered linear impressions and lack of organization into a distinct fan shape contrast with the more developed fans shown in figure 2. Sample is shown at natural size. Individual linear traces are about $1 \mathrm{~mm}$ wide and as long as $10 \mathrm{~mm}$.

2. Oldhamia sp. from beds assigned by Brabb and Churkin (1969) to the Adams Argillite in Nation area. UAK A-1023. Specimen is shown at natural size. Individual linear traces are about $1 \mathrm{~mm}$ wide and as long as $10 \mathrm{~mm}$.

3. Tabulaconus kordeae from archeocyathid-rich limestone in the Adams Argillite, southern Tatonduk area. UAK A-922. Bar is $5 \mathrm{~mm}$ long.

4, 5. ?Arthropoda Type C, from southeastern Woodchopper area. UAK EU 3. Numerous carapace(?) layers collapsed in mass to left in figure 5 include oval structure (lower left) with inner nonlamellar material surrounding collapsed membrane-bounded tube. Bar is $100 \mu \mathrm{m}$ long in figure 4; bar is $50 \mu \mathrm{m}$ long in figure 5 . 
U.S. GEOLOGICAL SURVEY
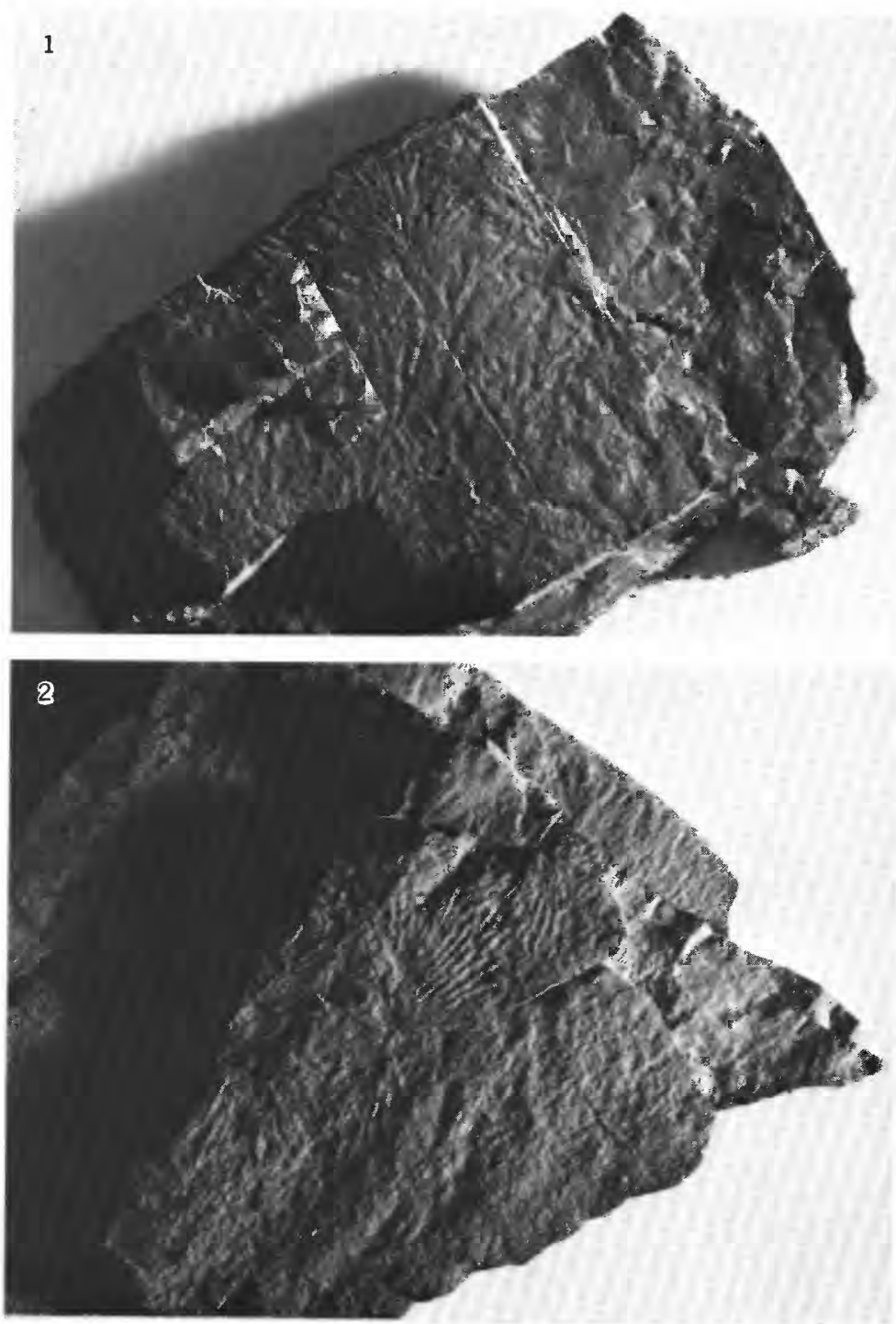

PROFESSIONAL PAPER 1449 PLATE 18
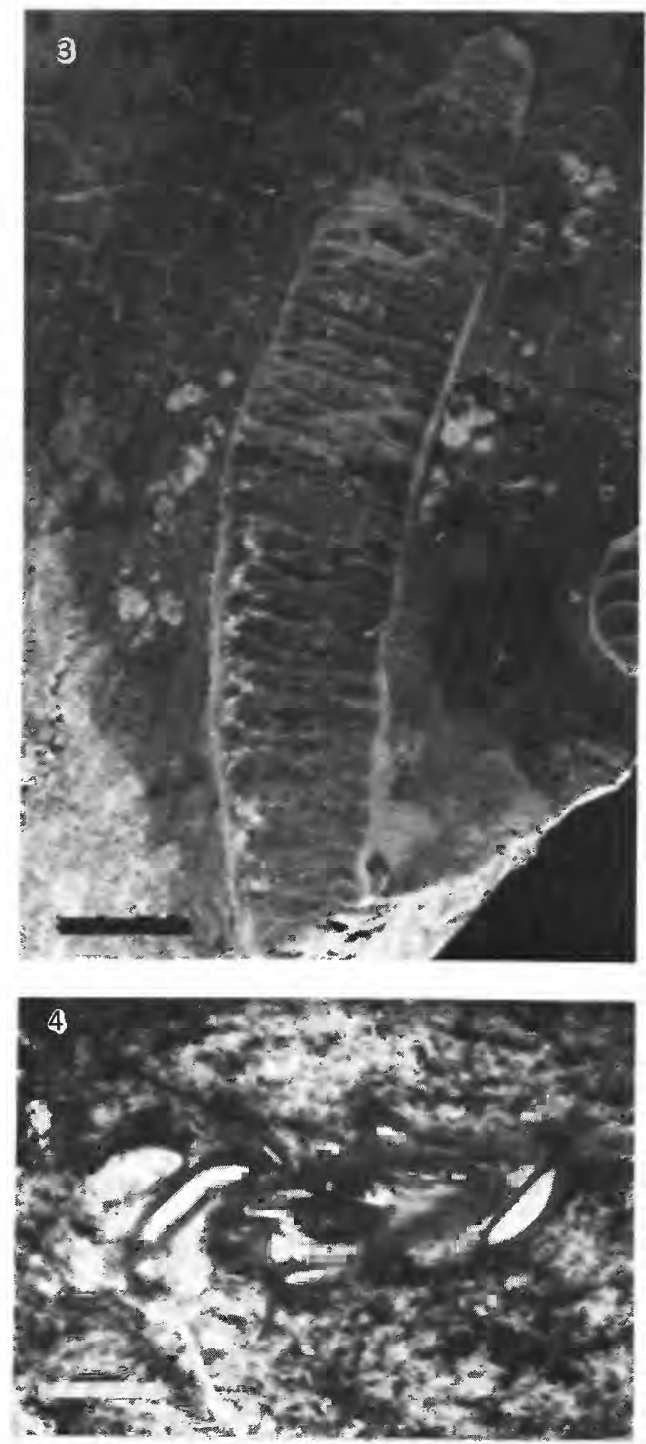

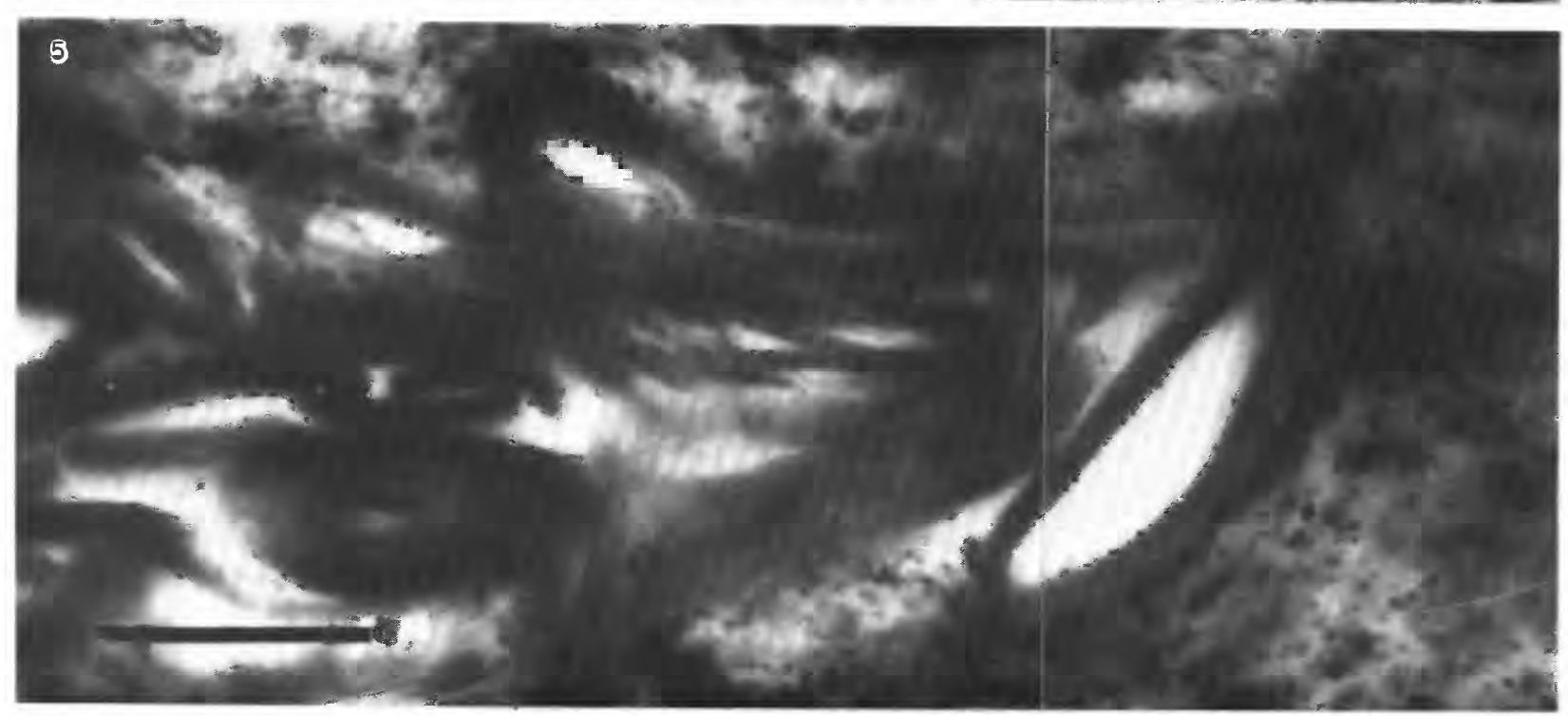

OLDHAMIA, ?OLDHAMIA, TABULACONUS, AND ?ARTHROPODA 


\section{SELECTED SERIES OF U.S. GEOLOGICAL SURVEY PUBLICATIONS}

\section{Periodicals}

Earthquakes \& Volcanoes (issued bimonthly).

Preliminary Determination of Epicenters (issued monthly).

\section{Technical Books and Reports}

Professional Papers are mainly comprehensive scientific reports of wide and lasting interest and importance to professional scientists and engineers. Included are reports on the results of resource studies and of topographic, hydrologic, and geologic investigations. They also include collections of related papers addressing different aspects of a single scientific topic.

Bulletins contain significant data and interpretations that are of lasting scientific interest but are generally more limited in scope or geographic coverage than Professional Papers. They include the results of resource studies and of geologic and topographic investigations; as well as collections of short papers related to a specific topic.

Water-Supply Papers are comprehensive reports that present significant interpretive results of hydrologic investigations of wide interest to professional geologists, hydrologists, and engineers. The series covers investigations in all phases of hydrology, including hydrogeology, availability of water, quality of water, and use of water.

Circulars present administrative information or important scientific information of wide popular interest in a format designed for distribution at no cost to the public. Information is usually of short-term interest.

Water-Resources Investigations Reports are papers of an interpretive nature made available to the public outside the formal USGS publications series. Copies are reproduced on request unlike formal USGS publications, and they are also available for public inspection at depositories indicated in USGS catalogs.

Open-File Reports include unpublished manuscript reports, maps, and other material that are made available for public consultation at depositories. They are a nonpermanent form of publication that may be cited in other publications as sources of information.

\section{Maps}

Geologic Quadrangle Maps are multicolor geologic maps on topographic bases in 71/2-or 15 -minute quadrangle formats (scales mainly $1: 24,000$ or $1: 62,500$ ) showing bedrock, surficial, or engineering geology. Maps generally include brief texts; some maps include structure and columnar sections only.

Geophysical Investigations Maps are on topographic or planimetric bases at various scales; they show results of surveys using geophysical techniques, such as gravity, magnetic, seismic, or radioactivity, which reflect subsurface structures that are of economic or geologic significance. Many maps include correlations with the geology.

Miscellaneous Investigations Series Maps are on planimetric or topographic bases of regular and irregular areas at various scales; they present a wide variety of format and subject matter. The series also includes $71 / 2$-minute quadrangle photogeologic maps on planimetric bases which show geology as interpreted from aerial photographs. Series also includes maps of Mars and the Moon.
Coal Investigations Maps are geologic maps on topographic or planimetric bases at various scales showing bedrock or surficial geology, stratigraphy, and structural relations in certain coal-resource areas.

Oil and Gas Investigations Charts show stratigraphic information for certain oil and gas fields and other areas having petroleum potential.

Miscellaneous Field Studies Maps are multicolor or black-andwhite maps on topographic or planimetric bases on quadrangle or irregular areas at various scales. Pre-1971 maps show bedrock geology in relation to specific mining or mineral-deposit problems; post-1971 maps are primarily black-and-white maps on various subjects such as environmental studies or wilderness mineral investigations.

Hydrologic Investigations Atlases are multicolored or black-andwhite maps on topographic or planimetric bases presenting a wide range of geohydrologic data of both regular and irregular areas; principal scale is 1:24,000 and regional studies are at 1:250,000 scale or smaller.

\section{Catalogs}

Permanent catalogs, as well as some others, giving comprehensive listings of U.S. Geological Survey publications are available under the conditions indicated below from the U.S. Geological Survey, Books and Open-File Reports Section, Federal Center, Box 25425, Denver, CO 80225. (See latest Price and Availability List.)

"Publications of the Geological Survey, 1879-1961" may be purchased by mail and over the counter in paperback book form and as a set of microfiche.

"Publications of the Geological Survey, 1962- 1970" may be purchased by mail and over the counter in paperback book form and as a set of microfiche.

"Publications of the U.S. Geological Survey, 1971- 1981" may be purchased by mail and over the counter in paperback book form (two volumes, publications listing and index) and as a set of microfiche.

Supplements for 1982, 1983, 1984, 1985, 1986, and for subsequent years since the last permanent catalog may be purchased by mail and over the counter in paperback book form.

State catalogs, "List of U.S. Geological Survey Geologic and Water-Supply Reports and Maps For (State), " may be purchased by mail and over the counter in paperback booklet form only.

"Price and Availability List of U.S. Geological Survey Publicathons," issued annually, is available free of charge in paperback booklet form only.

Selected coples of a monthly catalog "New Publications of the U.S. Geological Survey" available free of charge by mail or may be obtained over the counter in paperback booklet form only. Those wishing a free subscription to the monthly catalog "New Publications of the U.S. Geological Survey" should write to the U.S. Geological Survey, 582 National Center, Reston, VA 22092.

Note.--Prices of Government publications listed in older catalogs, announcements, and publications may be incorrect. Therefore, the prices charged may differ from the prices in catalogs, announcements, and publications. 